\title{
DESENVOLVIMENTO E PRODUTIVIDADE DO MORANGUEIRO SOB DIFERENTES NIVEIS DE ÁGUA E COBERTURAS DO SOLO
}

\section{REGINA CÉLIA DE MATOS PIRES \\ Engenheiro Agrônomo}

Orientador: Prof. Dr. MARCOS VINÍCIUS FOLEGATTI

Tese apresentada à Escola Superior de Agricultura

"Luiz de Queiroz", da Universidade de São Paulo, para obtenção do titulo de Doutor em Agronomia, Área de Concentração: Irrigação e Drenagem.

PIRACICABA

Estado de São Paulo - Brasil

Junho - 1998 
Dados Internacionais de Catalogação na Publicação (CIP)

DIVISÃO DE BIBLIOTECA E DOCUMENTAÇÃO - Campus "Luiz de Queiroz"/USP

Pires, Regina Célia de Matos

Desenvolvimento e produtividade do morangueiro sob diferentes niveis de água e coberturas do solo / Regina Célia de Matos Pires. - Piracicaba, 1998.

$116 \mathrm{p}$.

Tese (doutorado) - - Escola Superior de Agricultura Luiz de Queiroz, 1998.

Bibliografia.

1. Cobertura do solo 2. Crescimento vegetal 3. Cultivo protegido 4. Fitossanidade 5. Irrigação 6. Morango 7. Produtividade agrícola 8. Raiz I. Título

CDD 634.75 


\section{DESENVOLVIMENTO E PRODUTIVIDADE DO MORANGUEIRO SOB DIFERENTES NÍVEIS DE ÁGUA E COBERTURAS DO SOLO}

REGINA CÉLIA DE MATOS PIRES

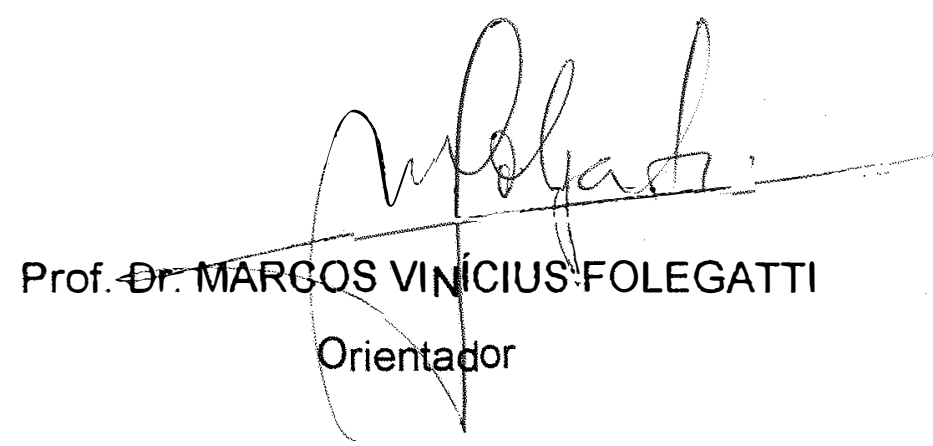


Aos meus pais

Maria dos Anjos e Armando

dedico este trabalho.

Ao meu marido Anicésio

e a Marilia minha filha

Ofereço. 


\section{AGRADECIMENTOS}

- A Deus pela vida, fé e esperança.

- Ao Professor Dr. Marcos Vinícius Folegatti pela orientação, apoio, amizade e estímulo durante a realização do curso.

- Aos Professores Dr. José Antônio Frizzone, Dr. João Tessarioli Neto, Dr. Sérgio Nascimento Duarte e aos Pesquisadores Dr. Francisco Antônio Passos, Dr. Flávio B. Arruda e Dr. Emílio Sakai, pelas valiosas sugestões.

- Aos Pesquisadores Científicos Dr ${ }^{a}$. Celi Teixeira Feitosa, Dr. Francisco Antônio Passos, Dr ${ }^{a}$. Maria Aparecida de Souza Tanaka e Dr. Mário José Pedro Júnior, pelo valiosa colaboração na obtenção dos dados, sugestões e apoio constante.

- À Dra . Gláucia M. B. Ambrosano, pela orientação e apoio nas análises estatísticas.

- Ao Professor Dr. Keigo Minami pelo incentivo e estímulo.

- Ao Professor Joaquim Santana Caixeta pelas sugestões e estímulo.

- Às bibliotecárias Kátia M. de Andrade Ferraz e Eliana M. Garcia Sabino pela correção das referências bibliográficas e apoio constante.

- Ao Curso de Pós-Graduação em Irrigação e Drenagem da Escola Superior de Agricultura "Luiz de Queiroz" (ESALQ) pela oportunidade concedida para realização do Curso.

- Ao Instituto Agronômico de Campinas (IAC) pela liberação para realização do Curso de Pós-Graduação.

- Aos Professores do Curso de Pós-Graduação em Irrigação e Drenagem pelos ensinamentos.

- Ao irmãos Osvaldo José Mazieiro, José Benedito Mazieiro e Luiz Donizetti Mazieiro, por possibilitarem a instalação dos experimentos em campo de produção comercial e pelo apoio e incentivo à pesquisa no morangueiro. 
- Ao Técnico Agrícola Aparecido Pereira Bueno, pelo empenho e dedicação na execução do trabalho de campo.

- À Associação de Produtores de Morango e Hortifrutigranjeiros de Atibaia, Jarinu e Região, Job Produtos Agrícolas e Hortec, pela concessão de materiais e equipamentos para o presente trabalho.

- Às Seções de Climatologia Agrícola, Fertilidade do Solo e Nutrição de Plantas, Fitopatologia, Hortaliças de Frutos pela colaboração.

- Aos funcionários da Seção de Irrigação e Drenagem do IAC: Emílio Sakai, Flávio B. Arruda, Mamor Fujiwara, Carmelina A. Fazani, Leonardo R. Teixeira, Leonice F. Silva, Louise Aranha e José F. de Oliveira, pelo apoio, estímulo e ambiente agradável.

- Aos colegas do Curso de Pós-Graduação em Irrigação e Drenagem, pelo companheirismo e convívio agradável.

- Aos funcionários do Departamento de Engenharia Rural, em especial ao Gilmar B. Grigolon, pela colaboração.

- Aos Técnicos Agrícolas Sr. Romilson C. M. Yamamura e Denilson C. Moraes, pela colaboração prestada.

- Aos colegas Elaine B. Wutke, Hipólito A. Mascarenhas, Rose M. Pio e Selma Regina R. Maggioto, pelo apoio, sugestões e convívio agradável.

- À Maria de Fátima e Wilson Piau pela amizade e apoio.

- Ao Conselho Nacional de Desenvolvimento Científico e Tecnológico (CNPq) e à Coordenadoria de Aperfeiçoamento de Pessoal de Nível Superior (CAPES) pela concessão de bolsa de estudo. 


\section{SUMÁRIO}

Página

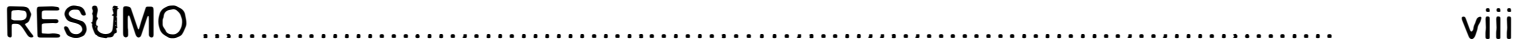

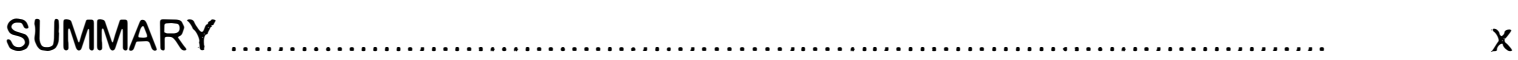

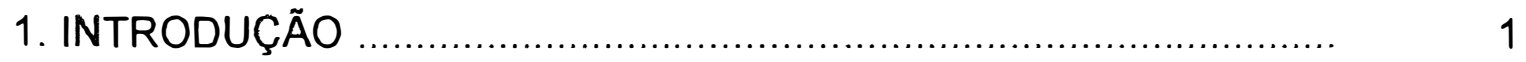

2. REVISÃO DE LITERATURA ................................................... 3

2.1. Considerações gerais .......................................................... 3

2.2. Efeitos do clima e do ambiente de cultivo no morangueiro ............ 3

2.3. Cobertura do solo .................................................................... 9

2.3.1. Efeito da cobertura do solo na produção .................................... 9

2.3.2. Efeito da cobertura plástica na temperatura do solo .................. 12

2.3.3. Efeito da cobertura plástica e desinfestação do solo na incidência de doenças ............................................................. 15

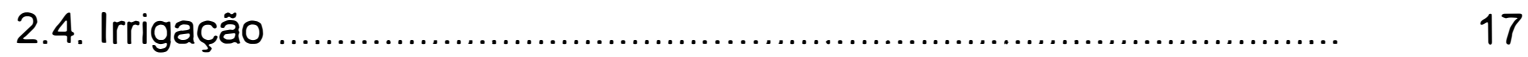

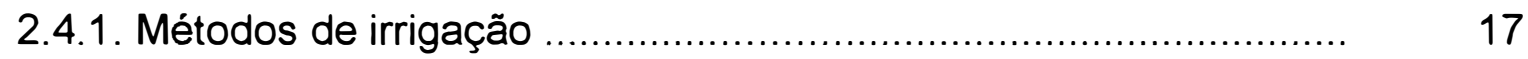

2.4.2. Manejo das irrigações .................................................... 20

2.4.2.1. Generalidades ................................................................. 20

2.4.2.2. Sensibilidade ao déficit hídrico .......................................... 21

2.4.2.3. Profundidade do sistema radicular ..................................... 24

2.4.2.4. Manejo da água .................................................................... 25

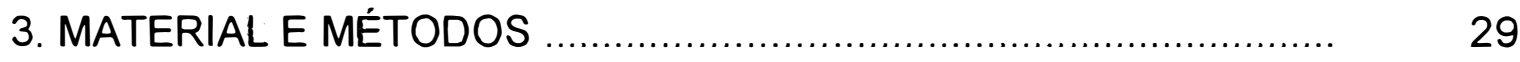

3.1. Local, clima e período de experimentação ..................................... 29

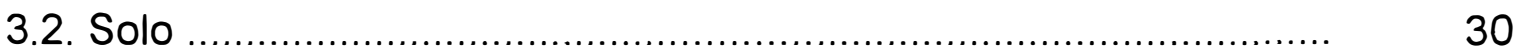

3.3. Delineamento experimental e análise dos dados ......................... 33

3.4. Cultivar e época de plantio ......................................................... 34

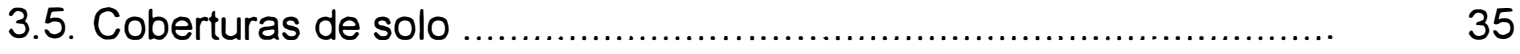

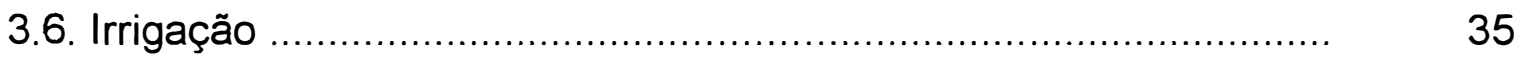




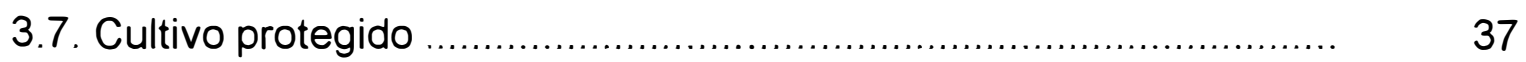

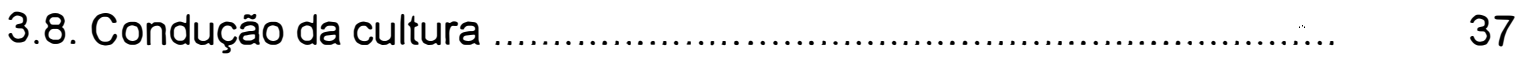

3.9. Medidas físicas do ambiente .................................................. 39

3.10. Avaliação do teor de nutrientes nas folhas ................................ 42

3.11. Avaliação da Sanidade das plantas........................................ 42

3.12. Avaliação do desenvolvimento vegetativo ................................. 44

3.12.1. Avaliação no campo aberto durante o ciclo da cultura .............. 44

3.12.2. Avaliação no cultivo protegido durante o ciclo da cultura ......... 45

3.12.3. Desenvolvimento vegetativo no final do ciclo ........................ 46

3.13. Avaliação do sistema radicular ............................................... 47

3.14. Avaliação do impedimento físico a penetração no solo ............... 48

3.15. Resistência estomática ao fluxo de difusão de vapor de água ..... 48

3.16. Avaliação da produção ........................................................ 49

4. RESULTADOS E DISCUSSÃO .............................................. 50

4.1. Temperatura do solo ................................................... 50

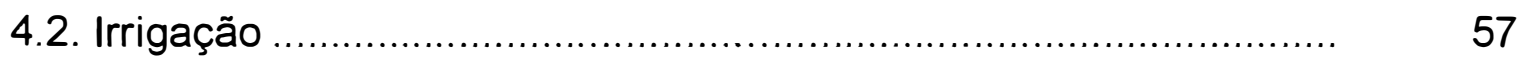

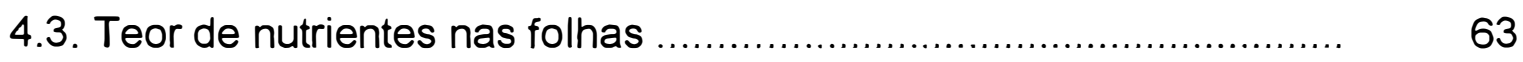

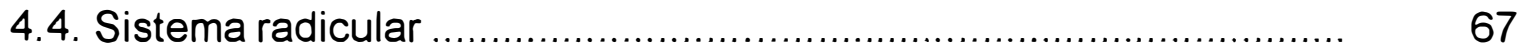

4.5. Avaliação da sanidade das plantas ......................................... 71

4.6. Desenvolvimento vegetativo ........................................ 78

4.6.1. Desenvolvimento vegetativo no cultivo a campo aberto ............. 78

4.6.2. Desenvolvimento vegetativo no cultivo protegido ..................... 80

4.6.3. Avaliação final do desenvolvimento vegetativo ........................ 83

4.6.4. Correlações simples das variáveis de desenvolvimento. vegetativo no final do ciclo ................................................. 85

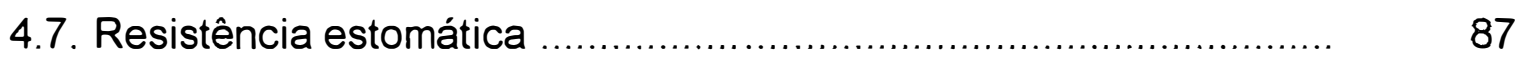

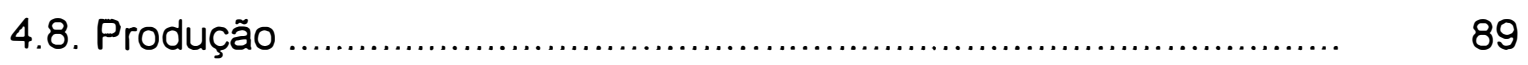

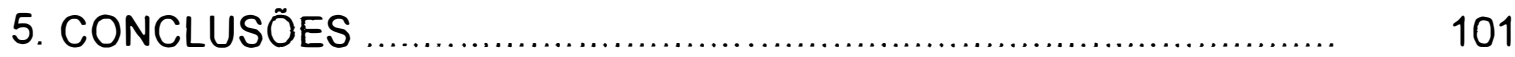

REFERÊNCIAS BIBLIOGRÁFICAS ......................................... 102 


\title{
DESENVOLVIMENTO E PRODUTIVIDADE DO MORANGUEIRO SOB DIFERENTES NIVEIS DE ÁGUA E COBERTURAS DO SOLO
}

\author{
Autora: REGINA CÉLIA DE MATOS PIRES \\ Orientador: Prof. Dr. MARCOS VINÍCIUS FOLEGATTI
}

\section{RESUMO}

Experimentos com a cultura do morangueiro em área de produção comercial foram realizados em ambiente protegido e a céu aberto, no período de abril a dezembro de 1995 em Atibaia, SP. O objetivo do presente trabalho foi avaliar o efeito de diferentes níveis de água e coberturas do solo no desenvolvimento, na sanidade e na produtividade do morangueiro. Os experimentos foram instalados no esquema fatorial $2 \times 3$, consistindo de duas coberturas do solo e de três níveis de irrigação, com cinco repetições. As coberturas de solo utilizadas foram o plástico transparente e o plástico preto. $A$ irrigação localizada foi aplicada por gotejo, sempre que o potencial de água no solo atingia valores de $-0,010,-0,035$ ou $-0,070 \mathrm{MPa}$ a $10 \mathrm{~cm}$ de profundidade.

No cultivo protegido, os níveis de água de -0,010 e -0,035 MPa e o uso do plástico transparente favoreceram o desenvolvimento vegetativo, a produção e seus componentes (número e peso médio dos frutos). O nível de irrigação de $-0,070 \mathrm{MPa}$ e o uso do plástico preto como cobertura proporcionaram a maior incidência de doenças.

Em condições de campo aberto, não houve efeito dos níveis de irrigação e das coberturas do solo no desenvolvimento vegetativo, na profundidade efetiva das raízes, na produção e em seus componentes (número 
e peso médio dos frutos), e na sanidade das plantas. A profundidade efetiva do sistema radicular do morangueiro foi de $30 \mathrm{~cm}$.

O comportamento fitossanitário ao longo do ciclo da cultura foi diferente nos ambientes estudados. No cultivo protegido, as doenças se desenvolveram apenas a partir da segunda quinzena de setembro, enquanto que no campo aberto a ocorrência foi desde o mês de junho. 


\title{
STRAWBERRY GROWTH AND YIELD UNDER DIFFERENT WATER LEVELS AND SOIL COVERS
}

\author{
Author: REGINA CÉLIA DE MATOS PIRES \\ Adviser: Prof. Dr. MARCOS VINÍCIUS FOLEGATTI
}

\section{SUMMARY}

This experiment was carried out at Atibaia-SP with strawberry crop cultivated inside greenhouse and in the field conditions during the period of April to December of 1995 . The aim of this work was to evaluate the effect of different water levels and soil covers in plant growth, yield and health conditions. The experimental design was a factorial $2 \times 3$ with five replications, and consisted of two soil covers and three water levels. The soil covers were clear and black plastics. The trickle irrigation was applied whenever the soil water potential reached $-0,010,-0,035$ or $-0,070 \mathrm{MPa}$ at a depth of ten centimeters.

The plants cultivated inside greenhouse with the soil water potential of $-0,010$ and $-0,035 \mathrm{MPa}$, and the clear plastic provided better development of plants, number of fruits, average weight of the fruits and yield. The irrigation level of $-0,070 \mathrm{MPa}$ and the use of the black plastic led to a greater disease incidence.

Under field conditions there was no effect of water levels and soil covers on the plant health, vegetative growth, root development, number of fruit, average weight and yield. The effective root depth considered for irrigation purpose was $30 \mathrm{~cm}$. 
The plant health conditions were not similar in the two experiments during the growth period. Under greenhouse the crop diseases developed from September 15th, onwards, and under field conditions the diseases started in June. 


\section{INTRODUÇÃO}

O morangueiro é uma planta cultivada em diferentes regiões no mundo, sendo os principais produtores os Estados Unidos, a Espanha, o Japão, a Itália e a Polônia (FAO, 1995). Segundo a Secretaria da Agricultura e Abastecimento de São Paulo (1996), a produção de morangos no Brasil está estimada em 35 mil toneladas anuais, da qual o Estado de São Paulo produz cerca de $80 \%$. Nesse Estado a produção se destina principalmente ao consumo "in natura". Os principais municipios produtores em 1995 foram Atibaia, Piedade, Bom Jesus dos Perdões, Cabreúva, Itapeva, Jundiaí, Jarinu e Louveira. Dentre esses, Atibaia contribuiu com $43 \%$ da produção do Estado.

Lisbão et al. (1991) relataram um aumento da área plantada com morangueiro em São Paulo, no período de 1987 a 1989, porém, com queda na produtividade, de 35 a 40 t/ha para 26 a 34 t/ha. Essa queda está relacionada, principalmente, à sanidade insatisfatória das plantas, sendo acentuada em alguns municípios do Estado, dentre eles Atibaia. Os problemas fitossanitários decorrem do manejo inadequado de algumas práticas culturais como: preparo do solo, adubação, calagem, irrigação, falta de aplicação das técnicas adequadas de conservação do solo, rotação de culturas e de produção de mudas sadias, entre outros. Antes do agravamento dos problemas de sanidade das plantas, a produtividade paulista do morangueiro aproximava-se dos patamares alcançados na Califórnia (54,9 t/ha) conforme citam Bringhurst et al. (1990). Deve-se lembrar porém, que o cultivo na Califórnia é realizado com elevado nível tecnológico, inclusive com desinfestação do solo. 
A influência da utilização de técnicas culturais no morangueiro tem sido estudada em diferentes regiões no mundo, com destaque para as coberturas do solo que proporcionam aumento na produtividade. Entretanto, o desempenho entre as diferentes coberturas no desenvolvimento e na produção de frutos, é frequentemente conflitante (Passos, 1997). A irrigação e o cultivo protegido, pelo efeito significativamente positivo na produtividade do morangueiro, também são técnicas investigadas mundialmente.

A irrigação é uma prática essencial para o cultivo do morangueiro no Estado de São Paulo. Entretanto, o excesso de água aplicada, bem como o modo de aplicação, pode propiciar condições favoráveis ao desenvolvimento de doenças de difícil controle, que levam à queda na produtividade da cultura (Maas, 1984). McNiesh et al. (1985) entre outros salientam que o morangueiro é sensivel ao déficit e ao excesso de água, ressaltando a importância do manejo da irrigação.

No Brasil, tradicionalmente, se cultiva morango a campo aberto, enquanto que, em algumas regiões do mundo, o cultivo protegido tem sido utilizado com a finalidade de proteção contra os rigores climáticos e melhor controle de doenças. Na região de Atibaia, no início da década de 90 , o cultivo protegido, aliado à irrigação por gotejamento, foi introduzido como tentativa de controle da antracnose em flores e frutos jovens no morangueiro (Passos, 1997).

A hipótese do presente trabalho é que a adoção de diferentes sistemas de cultivo, envolvendo práticas culturais e ambientes de cultivo, influencia o desenvolvimento do morangueiro. Para dar suporte a essa hipótese foram realizados experimentos com o objetivo de avaliar 0 desenvolvimento, a produtividade e a sanidade das plantas, em duas condições distintas de cultivo, a campo aberto e em cultivo protegido, sob diferentes niveis de água no solo e coberturas de canteiro. 


\section{REVISÃO DE LITERATURA}

\subsection{Considerações gerais}

O morangueiro é uma planta pertencente à família Rosaceae, gênero Fragaria, conforme descrito por Camargo (1960). A classificação botânica aceita atualmente para os cultivares comerciais é Fragaria $X$ ananassa Duch. (Hancock, 1990). É uma planta herbácea, de porte baixo e extremamente dependente de condições ambientais favoráveis para se desenvolver com elevado potencial produtivo (Groppo \& Tessarioli Neto, 1991). Embora seja uma planta perene, o seu cultivo é anual, devido à queda de produtividade e qualidade do produto.

\subsection{Efeitos do clima e do ambiente de cultivo no morangueiro}

A interação entre o fotoperíodo e a temperatura determina a adaptação e o desenvolvimento de uma cultivar a determinada localidade (Dennis et al., 1970; Galletta \& Bringhurst, 1990). Segundo Filgueira (1982) a temperatura afeta decisivamente a qualidade dos frutos, sendo fator limitante à expansão da cultura no centro sul do país. Regiões mais quentes produzem morangos mais ácidos e menos saborosos. Por outro lado, regiões de clima 
temperado, com dias ensolarados e noites frias, produzem frutos com melhor sabor, sendo mais adocicados e com aroma agradável. Ainda, segundo o mesmo autor, o comprimento do dia afeta o desenvolvimento da cultura, sendo que os dias curtos estimulam a frutificação, e os dias longos favorecem a fase vegetativa, estimulando a emissão de estolhos. Segundo Carbonari \& Cunha (1975) o fotoperiodo indutivo da floração do cultivar Campinas é de doze horas.

Os cultivares mais utilizados atualmente no Brasil necessitam de dias curtos para floração e frutificação. Segundo Passos et al. (1998) os mais adequados para o consumo ao natural e para congelamento são: Campinas (IAC-2712), AGF-80, Chandler, Sequóia, Korona, Reiko (ou Leiko), Oso Grande, IAC Princesa Isabel, Dover e Toyonoka, entre outros.

Segundo Galletta \& Bringhurst (1990) o morangueiro é uma planta sensivel aos estímulos ambientais. O desenvolvimento vegetativo ocorre em ampla faixa de temperatura do ar, acima do congelamento e abaixo de $35^{\circ} \mathrm{C}$, sendo a melhor faixa de 20 a $26^{\circ} \mathrm{C}$. Estes são valores médios para o morangueiro, podendo variar com o cultivar. Ainda com referência a valores médios de temperatura do ar, Sganzerla (1995) cita que a melhor faixa de temperatura para o desenvolvimento do morangueiro é a de 14 a $30^{\circ} \mathrm{C}$. Passos et al. (1998) ressaltam que a temperatura do ar acima de $30^{\circ} \mathrm{C}$ inibe a floração e estimula a produção de estolhos, e abaixo de $9^{\circ} \mathrm{C}$ há inibição no desenvolvimento vegetativo do morangueiro.

luchi (1993) observou que o aumento da temperatura e do fotoperíodo no verão diminuiram o florescimento do morangueiro, ocorrendo emissão de estolhos e queda parcial de folhas, com alteração da partição de assimilados. Ainda segundo o mesmo autor, que desenvolveu experimentos em condições de casa-de-vegetação, em Viçosa, Minas Gerais, as condições meteorológicas de radiação solar incidente e de temperatura são melhores para o desenvolvimento das plantas e produção de frutos de morangueiro a céu aberto do que em casa-de-vegetação. 
No Brasil, quase a totalidade da área plantada com morangueiro é cultivada a céu aberto. Por outro lado, em regiões onde seu cultivo está melhor desenvolvido (Europa, Israel, Japão e algumas regiões dos Estados Unidos), utiliza-se o cultivo protegido (Sganzerla, 1995).

O uso de estufas plásticas (cultivo protegido) vem crescendo nos últimos anos no Brasil. Sua utilização altera elementos do clima. O polietileno transparente de baixa densidade (PEBD) é o material mais utilizado na cobertura dessas estufas. Vários estudos têm sido desenvolvidos para avaliar a transmissividade desse material.

Robledo \& Martin ${ }^{1}$, citados por Camacho et al. (1995) relatam que a transmissividade do material de cobertura da estufa à radiação solar depende de sua composição, espessura, tempo de exposição às condições ambientais, deposição de poeiras, ângulo de incidência dos raios solares, orientação e arquitetura da estufa, condições atmosféricas no momento das determinações e condensação de água nas paredes internas do plástico.

Farias et al. (1993a) e Camacho et al. (1995) mediram a transmissividade à radiação solar global da cobertura plástica (PEBD) em estufas, bem como seu efeito dispersante, em Capão do Leão, RS. Nas estufas, a radiação solar global foi em média $80 \%$ da ocorrida no ambiente externo. Por outro lado, a radiação solar difusa, ocorrida a campo aberto, foi inferior à medida na estufa. Os autores ressaltam que o aumento da radiação difusa é desejável, pois, sendo multidirecional, é mais efetiva na fotossíntese, penetrando melhor entre as plantas, podendo compensar em parte a menor transmissividade à radiação solar global provocada pela cobertura plástica. Pezzopane (1994) observou que essa perda na transmissividade da radiação solar nas estufas também varia durante 0 ano, devido ao movimento do sol ou às alterações nas características físicas do filme plástico, com o tempo.

\footnotetext{
${ }^{1}$ ROBLEDO. F.P.: MARTIN. L.V. Aplicación de los plásticos en la agricultura. Madrid:Mundi-Prensa, 1988. 553p.
} 
Vários trabalhos têm sido realizados com o objetivo de investigar alterações na temperatura do ar sob condições de cultivo protegido. Segundo Farias et al. (1993b) a influência do cultivo protegido na temperatura do ar está relacionada ao seu efeito no balanço de energia, ao tamanho e volume da estufa e ao tipo de solo. De um modo geral, a temperatura no interior de estufas atinge alguns graus acima daquela verificada no ambiente externo (Sganzerla, 1995).

Com relação à temperatura máxima do ar no interior de estufas, existe concordância entre os resultados de vários estudos realizados no Brasil e na Espanha, sendo sempre maior que a ocorrida a campo aberto (Montero et al., 1985; Farias et al., 1993b; luchi, 1993; Buriol et al., 1995; Camacho et al., 1995; Pezzopane et al., 1995 e Alves \& Klar, 1996).

Com relação ao efeito de estufa plástica (tipo capela) sobre a temperatura mínima, Montero et al. (1985) e Farias et al. (1993b) concluíram que os valores obtidos foram muito semelhantes à condição externa. Farias et al. (1993b) relacionam esse fato à alta transmissividade do PEBD, que deixa passar até $80 \%$ da radiação de ondas longas (radiação térmica) emitida pelos corpos no interior da estufa e, desta forma, não permite que o efeito estufa se acentue. Resultados similares também foram obtidos por Camacho et al. (1995), os quais relatam que, além das perdas de radiação, a estufa também perde energia por condução-convecção, através da cobertura, pelas aberturas existentes e pelo fluxo de calor no solo.

Para as condições de Santa Maria, RS, Buriol et al. (1993) obtiveram, em média, os valores de temperatura mínima do ar no interior de vários tipos de estufa, sempre maiores em relação aos ocorridos no ambiente externo, tanto a $1,5 \mathrm{~m}$ como a $0,05 \mathrm{~m}$ da superfície do solo.

Pezzopane et al. (1995) observaram em estufa com cobertura em arco, em Campinas, SP, que em noites frias, com temperatura mínima menor que $10^{\circ} \mathrm{C}$, a mínima da estufa foi sempre maior que a observada a campo 
aberto. Por outro lado, em algumas noites com vento moderado e geralmente com céu límpido ou parcialmente encoberto, com temperaturas mínimas maiores que $14^{\circ} \mathrm{C}$, os menores valores foram observados na estufa.

Passos (1997), comparando cultivo protegido com cultivo em campo aberto, no cultivo do morangueiro em Atibaia, SP, observou que, as temperaturas do ar e do solo não foram afetadas pelo ambiente de cultivo. A ausência de diferenças entre os valores de temperatura pode ter sido conseqüência do manejo das cortinas que ficaram totalmente levantadas durante a maior parte do periodo experimental, além do fato das estufas serem estreitas e não possuírem proteção lateral.

Por outro lado, com relação à temperatura do solo, Schneider et al. (1993) observaram que, no interior da estufa, os valores foram sempre maiores, em relação aos do ambiente externo, independente da profundidade e do horário de medida. Já Martins et al. (1994) constataram maior temperatura do solo no cultivo do tomateiro a campo aberto do que sob casa-de-vegetação, durante a maior parte do dia, e justificaram essa ocorrência pelo baixo crescimento das plantas e alto índice de mortalidade das mesmas, no campo.

A influência da temperatura do solo, em dois cultivares de morangueiro, foi relatada por Galletta \& Bringhurst (1990). O crescimento da planta diminuiu, quando ocorreram valores extremos de temperatura do solo, sendo satisfatório na faixa de 12,8 a $29,4^{\circ} \mathrm{C}$, para o cv. Shasta, e de 7,2 a $29,4^{\circ} \mathrm{C}$, para o cv Lassen. Em média, o crescimento da planta foi otimizado, quando a temperatura do solo foi de $23,9^{\circ} \mathrm{C}$. A produção de frutos foi maximizada por temperaturas do solo na faixa de 7,2 a $12,8^{\circ} \mathrm{C}$.

Os valores de umidade relativa do ar (UR) no interior de estufas são intimamente relacionados aos valores de temperatura do ar. Farias et al. (1993b) observaram a interferência do estádio de desenvolvimento da cultura de feijão-vagem na variação da umidade relativa. Na fase inicial, com a cultura pouco desenvolvida, os valores de UR na estufa foram menores que os 
externos, ocorrendo, em seguida, um período de equilibrio entre os dois ambientes. Quando a cultura já estava bem desenvolvida, os valores internos foram maiores que os externos. Em média, foi observado que a UR máxima e a UR mínima ocorreram na estufa, diferindo em média 2,19 e 5,78\%, respectivamente, dos valores obtidos a campo aberto. Desta forma, a maior amplitude de variação ocorreu no cultivo protegido.

Pezzopane et al. (1995) encontraram maiores valores máximos de umidade relativa do ar (UR) na estufa, do que no ambiente externo. Observaram que a estufa praticamente não afetou os valores mínimos da UR. Estes resultados concordam com os obtidos por Montero et al. (1985), e diferem dos observados por Farias et al. (1993b), com relação à UR mínima. Pezzopane et al. (1995) observaram que resultados conflitantes do comportamento da umidade relativa em cultivo protegido e a campo aberto podem ser provenientes de diferenças no manejo das cortinas das estufas.

O conhecimento da influência dos elementos do clima, em cultivo a campo aberto ou em ambiente protegido, é de grande importância no cultivo do morangueiro (Galleta \& Bringhurst, 1990), pois interferem no desenvolvimento e na produtividade da cultura; além disso, podem, favorecer ou não o desenvolvimento de doenças de difícil controle (Maas, 1984 e Smith \& Black, 1987).

O uso do cultivo protegido para o morangueiro no Brasil deve ser estudado com cautela, pois em inúmeros trabalhos os autores verificaram que as temperaturas máximas do ar e do solo são maiores do que as ocorridas em campo aberto, condição esta que pode ser desfavorável ao desenvolvimento e à produção do morangueiro (Galletta \& Bringhurst, 1990). Por outro lado, o cultivo protegido pode ser favorável ao controle de algumas doenças do morangueiro, para as nossas condições (luchi, 1993 e Passos, 1997). Possivelmente, o desenvolvimento de estratégias que favoreçam a ventilação e 
propiciem proteção contra chuvas, geadas e orvalho devam levar a bons resultados, no uso do cultivo protegido para o morangueiro.

\subsection{Cobertura do solo}

No cultivo comercial do morangueiro, o uso de cobertura de solo no canteiro é prática comum. As principais vantagens do uso dessas coberturas estão associadas à possibilidade de controle de plantas daninhas, à redução de perda de água do solo por evaporação e produção de frutos limpos, sem contato com o solo.

Nas últimas décadas, tem sido muito investigado o uso de diversas coberturas do solo no cultivo do morangueiro, seja com materiais permeáveis (palhas, acículas de pinus, folhas, serragem, entre outros) ou impermeáveis, como os filmes plásticos (Tessarioli Neto, 1993), ou a combinação de ambos (Passos, 1997).

\subsubsection{Efeito da cobertura do solo na produção}

Passos (1997) relata que as coberturas do solo, tanto as permeáveis como as impermeáveis, têm resultado em maiores produções de morango, em relação ao solo descoberto.

A utilização de filmes plásticos, para cobertura do canteiro, tem resultado em aumento de produção de frutos, quando comparados a coberturas permeáveis ou ao solo descoberto (Martins, 1983; Himelrick et al., 1993; Tessariolli Neto, 1993; Gupta \& Acharya, 1993). Desde os anos 70, a maior 
parte dos produtores de morango no Estado de São Paulo utilizam o plástico preto para cobertura do solo dos canteiros (Olitta \& Minami, 1975).

Tessarioli Neto (1993), obteve maior produção precoce, peso médio dos frutos, desenvolvimento das plantas, área foliar, matéria seca da parte aérea e das raízes, com o uso do plástico preto como cobertura do solo em relação aos tratamentos com solo descoberto e com coberturas permeáveis. Gupta \& Acharya (1993) observaram maior desenvolvimento radicular, frutos mais adocicados, com baixa acidez, e aumento de $56 \%$ na produção no plástico preto em relação ao solo descoberto. Por outro lado, Camargo \& Igue (1973) verificaram maiores produções para o cv. Campinas, com o uso de coberturas mortas do que com o plástico preto. A redução de produção foi relacionada ao menor desenvolvimento das plantas e a maior incidência de antracnose quando se utilizou o plástico preto. Resultados semelhantes foram obtidos por Passos (1997) para esse mesmo cultivar, em Atibaia, SP. Com uso do polietileno preto houve um aumento da incidência de doenças causadas por um complexo de fungos, acarretando redução da matéria seca da parte aérea, da área foliar, da produção e do peso médio dos frutos, em relação à cobertura orgânica.

No Estado da California, EUA, Voth (1972) relatou que o uso do plástico transparente no plantio de inverno, aliado a outras práticas culturais e a novos cultivares, contribuiu para aumentos de produtividade da ordem de até $70 \%$ no cultivo do morangueiro, salientando ainda a grande importância da aplicação do plástico, logo após ao transplantio. Tal ganho de produção está fortemente associado ao efeito desse plástico no aquecimento do solo. Como o plástico transparente não inibe o desenvolvimento de plantas invasoras, faz-se necessária a fumigação do solo. Galletta \& Bringhurst (1990) salientam que, na Califórnia, o uso do plástico transparente aumentou a produtividade, e favoreceu a produção precoce. Por outro lado, esses autores observaram que, na Flórida, com o uso do plástico preto tem sido obtidos melhores resultados. 
No Peru, Franciosi et al. ${ }^{2}$, citados por Martins (1983) relatam que o plástico transparente também é utilizado em grande escala, com o objetivo de aumentar a produção de frutos e favorecer a sua precocidade.

Martins (1983) avaliou o efeito de diferentes coberturas de solo, plásticas (transparente, azul translúcido e preto), e orgânicas (cascas de arroz, acícula de Pinus e maravalha), sobre o rendimento de dois cultivares de morangueiro, o Monte Alegre e o Campinas, em comparação ao solo descoberto, em Viamão, RS. Não foram observadas diferenças significativas entre as produções obtidas nas coberturas plásticas, quando comparadas ao solo descoberto, embora tenha sido observada uma tendência de maior produção nas coberturas plásticas, principalmente no plástico transparente.

Voth \& Bringhurst (1990) apresentam resultados de produção de morangueiro obtidos com vários cultivares e coberturas plásticas no Estado da Califórnia. A maior produção foi obtida com o uso do plástico transparente nos diferentes cultivares estudados. Para alguns cultivares, o incremento na produção chegou a ser da ordem de $60 \%$ (variando de 20 a 60\%), quando comparado ao solo descoberto. Comparando-se as produções obtidas com os plásticos transparente e preto, verificou-se que a primeira, foi em média, $23 \%$ superior nos seis cultivares avaliados. Os cultivares que alcançaram maior produção em resposta ao uso do plástico transparente em relação ao preto foram: Selva, Chandler, Irvine, com aumentos de produção da ordem de 40, 32 e $31 \%$, respectivamente. Por outro lado, no cultivar C35 esse aumento foi de apenas $3 \%$. Tais resultados sugerem que o efeito da cobertura também varia com o cultivar.

Segundo Himelrick et al. (1993) os plásticos transparente e preto têm sido os mais utilizados nos Estados Unidos (California, Flórida, Carolina do Norte e Alabama). Os autores realizaram experimento no Estado do Alabama,

\footnotetext{
"FRANCIOSI, R.: DUARTE. O.; FIGUEROA. R.; MORIN. C. Cultivo de la fresa en el Peru. Lima, Ministério de Agricultura. 35p. (Boletim tecnico. 80).
} 
EUA, com os cultivares Selva e Chandler, em diferentes coberturas plásticas, além do solo descoberto, por periodo de dois anos. Em todos os canteiros foi feita fumigação do solo. Os resultados de produção na experimentação não foram conclusivos, dificultando a escolha do melhor cultivar e cobertura do solo. Os autores ressaltam que as temperaturas e precipitações ocorridas durante as duas estações de crescimento foram bem diferentes, e que isto pode ter levado à dificuldade, na análise do melhor desempenho das diferentes coberturas utilizadas.

Gupta \& Acharya (1993) obtiveram maior produção com plástico preto, quando comparado ao transparente no cultivo do morangueiro cv. Tioga, na Índia, de forma similar ao observado na Flórida conforme Galletta \& Bringhurst (1990).

A escolha da cobertura do solo, para melhor desenvolvimento e produtividade do morangueiro, é difícil, pois embora existam muitos trabalhos desenvolvidos na área, os resultados encontrados são conflitantes. Desta forma, o desempenho das coberturas parece estar associado a fatores edafoclimáticos, a condições de cultivo e ao cultivar utilizado (Passos, 1997).

\subsubsection{Efeito da cobertura plástica na temperatura do solo}

As coberturas plásticas afetam o microclima do solo pela alteração no saldo de radiação da superficie e por evitar a evaporação de água do solo (Liakatas et al., 1986). Tais fatores podem afetar a temperatura e a umidade do solo na zona das raizes e, consequentemente, o desenvolvimento vegetativo e a produtividade das plantas.

Liakatas et al. (1986) estudaram o efeito de coberturas do solo na temperatura e no fluxo de calor no mesmo, ressaltando que a temperatura média do solo, sob uma cobertura opaca, pode ser maior ou menor que a do 
solo descoberto, dependendo da refletividade do material e da camada de ar existente entre a cobertura e o solo. Segundo estes autores, por esse motivo, existem trabalhos com resultados contraditórios sobre temperatura do solo, em diferentes tipos de coberturas.

Segundo Ham et al. (1993) os efeitos de coberturas plásticas na temperatura do solo e da superfície, bem como no balanço de radiação, são determinados primariamente pelas propriedades ópticas do material (absortância, refletância, transmitância). Esses autores estudaram a influência dessas propriedades com relação à radiação de ondas curtas e longas, assim como seu efeito no regime de temperatura, em 8 coberturas plásticas, dentre elas o plástico preto e o transparente. A temperatura máxima do solo diferiu entre os plásticos testados. Exceto o plástico branco, todos os plásticos aumentaram a temperatura do solo, quando comparados ao solo descoberto. As temperaturas diárias máximas no polietileno transparente foram menores do que as ocorridas no plástico preto, resultado esse que não era esperado, uma vez que o plástico transparente é utilizado para prática de solarização do solo, por proporcionar maior aumento de temperatura do mesmo. Os autores concluiram que, provavelmente, ocorreu o aprisionamento de bolsões de ar, no momento da aplicação da cobertura no solo, formando assim uma camada isolante de ar, resultando em menor aquecimento do solo. Esse resultado demonstra que, tanto as propriedades ópticas do material, como a metodologia e os cuidados na aplicação da cobertura podem modificar o aquecimento do solo.

Martins (1983), para as condições de Viamão, RS, observou maiores temperaturas do solo com o uso do plástico azul translúcido, seguido, em ordem decrescente, pelo preto, o transparente, e finalmente pelo solo descoberto. $\mathrm{O}$ autor relata que as menores temperaturas encontradas com 0 uso do plástico transparente, quando comparadas às demais coberturas plásticas, podem ter sido influenciadas pelo desenvolvimento de plantas 
invasoras sob o mesmo. Estas sombrearam o solo, diminuindo o aquecimento pela radiação solar, e aumentando a camada de ar isolante entre o filme plástico e o solo, diminuindo o aquecimento do solo por condução. Além disso, outro aspecto que pode ter influenciado esse resultado é a forma de aplicação do plástico nos canteiros, conforme referem-se Liakatas et al. (1986) e Ham et al. (1993).

Segundo Liakatas et al. (1986) a cobertura transparente tem alta transmissividade de radiação para a superfície do solo, quando comparada às demais coberturas. Devido ao impedimento da dissipação de energia pela cobertura, esta aumenta tanto a temperatura média, como a amplitude térmica diária, quando comparada ao solo descoberto. O aumento da temperatura do solo no cultivo do morangueiro, alcançado pelo uso do plástico transparente associado a outras práticas culturais, propiciou aumento de produtividade da cultura no inverno, na região da California (Voth, 1972; Voth \& Bringhurst, 1990; Galletta \& Bringhurst, 1990).

Os resultados de várias investigações realizadas, comparando diferentes coberturas do solo no cultivo do morangueiro, incluindo plástico transparente e preto, dentre outros, mostram valores maiores da temperatura do solo sob polietileno transparente (Voth, 1972; Voth \& Bringhurst, 1990; Gupta \& Acharya, 1993; Himelrick et al., 1993).

A temperatura do solo é um parâmetro importante, para se comparar o efeito de diferentes coberturas do solo no cultivo do morangueiro. Conforme salientado por Liakatas et al. (1986) e Ham et al. (1993), além das características físicas do material utilizado, a metodologia de aplicação da cobertura pode interferir no comportamento térmico do solo, e por isso deve ser cuidadosamente verificada. 


\subsubsection{Efeito da cobertura plástica e desinfestação do solo na incidência de doenças}

Waggoner et al. ${ }^{3}$, citados por Martins (1983) relatam que a severidade do ataque do patógeno Rhizoctonia solani ao sistema radicular do morangueiro foi maior no cultivo com os plásticos aluminizados, preto e transparente, quando comparada à observada em solo descoberto. Dentre os plásticos utilizados, o ataque mais severo ocorreu com o uso do plástico preto.

Segundo Maas (1984), elevadas temperaturas e umidade relativa do ar favorecem o desenvolvimento de doença na parte aérea da planta; enquanto que no solo, as temperaturas de 2 a $18^{\circ} \mathrm{C}$ favorecem 0 ataque de Rhizoctonia solani às raízes do morangueiro.

Camargo \& Igue (1973) observaram, em experimento de campo, que a incidência da antracnose (Colletotrichum fragariae) foi mais severa no morangueiro cultivado com plástico preto, do que sob diversas coberturas mortas e em solo descoberto. Essa maior incidência foi atribuída ao maior aquecimento do solo proporcionado pelo plástico preto, quando comparado às demais coberturas estudadas.

A dispersão de Colletotrichum acutatum em frutos de morangueiro pelo impacto das gotas de água foi estudado por Yang et al. (1990). A dispersão do fungo foi mais intensa no cultivo com cobertura plástica, quando comparada à ocorrida na palha e no solo descoberto.

Passos (1997) encontrou maior incidência de doenças causadas por um complexo de fungos (Rhizoctonia spp., Fusarium spp., Pythium spp., Colletotrichum spp. e Verticillium dahliae), a partir do mês de outubro, no plástico preto, em relação à cobertura orgânica (farpas de madeira) e ao solo descoberto. Nesse período, as temperaturas do solo no plástico preto foram

\footnotetext{
${ }^{3}$ WAGGONER. P.E.: MILLER, P.M.: DE ROO, H.C. Plastic mulching: principles and benefits. New Haven. Connecticut Agricultural Experimental Station. 43p. (Bulletin. 634).
} 
superiores às ocorridas nas farpas de madeira. As plantas cultivadas com cobertura plástica tiveram redução da matéria seca da planta, área foliar, produção e peso médio dos frutos em relação à cobertura orgânica.

A resistência do morangueiro ao Colletotrichum fragariae é influenciada pelas condições ambientais, sendo que o aumento da temperatura acentua a severidade da doença (Smith \& Black, 1987). Maas (1984) acrescenta que, em condições de elevada umidade relativa do ar e fertilidade do solo alta, o desenvolvimento do Colletotrichum spp também é favorecido. Tanaka et al. (1995) observaram que, com o uso de doses crescentes de $\mathrm{N}$ houve aumento da severidade da doença no cultivar Campinas. Com relação ao Verticillium, segundo Figueiredo et al. (1971), o V. albo-atrum se desenvolve bem à temperatura do solo de 21 a $22^{\circ} \mathrm{C}$, enquanto $\circ \mathrm{V}$. dahliae $\circ$ faz em temperaturas mais elevadas, de 25 a $26^{\circ} \mathrm{C}$.

$O$ efeito das coberturas do solo na incidência de doenças parece estar relacionado principalmente às modificações microclimáticas causadas na utilização de cada cobertura do solo.

O uso do plástico transparente para cobertura de canteiros requer a fumigação do solo, para possibilitar o cultivo sem presença de plantas invasoras. Além desse aspecto, deve-se lembrar que a desinfestação do solo tem sido utilizada com êxito no cultivo do morangueiro, segundo Voth (1972), Voth \& Bringhurst (1990), Hartz et al. (1993) e Himelrick et al. (1993). Maas (1984) comenta que a desinfestação do solo tem resultado em bom controle para Verticillium spp., Pythium spp., Rhizoctonia solani e Fusarium spp.. Segundo Hartz et al. (1993), a combinação da fumigação do solo, do plástico transparente e da irrigação localizada tem resultado em produtividades médias acima de 40 tha, na Califórnia. Kimati (1995) comenta que com o uso do brometo de metila com cloropicrina, para o tratamento do solo, a produtividade do morangueiro foi aumentada de 15 para 44 tha. Apesar do efeito benéfico da desinfestação do solo na produtividade, Wing et al. (1995) alertam que caso o 
patógeno reapareça após a fumigação, é possivel que, a doença ocorra com alta severidade. Isto porque, após a desinfestação do solo a população de microorganismos é reduzida indistintamente, benéficos ou não.

Larson \& Shaw (1995) realizaram experimentos para avaliar o desempenho de doze genótipos de morangueiro na Universidade da Califórnia, cultivados em solo com e sem fumigação em pré-plantio. As plantas cultivadas em solo não fumigado produziram apenas cerca de $54 \%$ daquela obtida em solo tratado. Nos tratamentos com solo não fumigado, no início da cultura, o desenvolvimento vegetativo foi menor e desuniforme, e alcançou menor peso médio dos frutos. De acordo com os resultados observados, a produtividade do morangueiro aumentou substancialmente pela fumigação do solo, tanto em condições de ausência de patógenos letais, como em locais de cultivo contínuo com morangueiro, onde o solo já estava contaminado com patógenos.

\subsection{IRRIGAÇÃO}

\subsubsection{Métodos de irrigação}

No Brasil, a irrigação por aspersão é utilizada quase que na totalidade da área cultivada com morangueiro. A irrigação por aspersão, assim como as precipitações e as neblinas, propicia condições favoráveis ao desenvolvimento e disseminação de fungos e bactérias (Rotem \& Palti, 1969; Maas, 1984; Machado, 1985 e Rodrigues Neto et al., 1994), podendo acarretar queda de produtividade. Yang et al. (1990) e Yang et al. (1992) estudaram a disseminação de patógenos por meio dos respingos causados pelo impacto das gotas de água. 
O uso da irrigação por gotejamento tem como vantagens a ausência de aplicação de água na parte aérea da planta, possibilitando ainda automatização, irrigações frequentes e fertirrigação. Porém, este sistema, se mal manejado, pode levar a resultados negativos.

Alguns produtores não utilizam o gotejamento na fase de plantio e pegamento das mudas, pois o fato de serem de raízes nuas as tornam susceptíveis ao estresse hídrico. Entretanto, se as mudas com raiz nua fossem encanteiradas e plantadas no local definitivo com torrão de solo, ou, então, enraizadas em recipientes, como bandejas plásticas, esse problema poderia ficar equacionado.

O gotejamento já era utilizado com vantagens nos anos 70 no Estado da Califórnia, Estados Unidos, no cultivo do morangueiro. Voth (1972) relata redução no uso da água, ao longo do ciclo da cultura, e aumento na produção e no tamanho dos frutos com o uso do gotejamento.

Em experimentação realizada em Piracicaba, SP, Olitta \& Minami (1974) concluíram que o melhor desempenho em produção e desenvolvimento das plantas de morangueiro foi obtido com uso do gotejamento, quando comparado à irrigação por sulcos.

Locascio \& Myers (1975) e Locascio et al. (1977) em experimentação com morangueiro no Estado da Flórida, Estados Unidos, observaram diferenças significativas na produção, quando foram utilizados os sistemas de irrigação por aspersão e por gotejamento, comparados ao tratamento sem irrigação. Quando os fertilizantes nitrogenados e potássicos foram aplicados na fase de pré-plantio, as produções em ambos sistemas de irrigação foram semelhantes, porém um pouco maior no gotejamento. Quando parte do fertilizante foi aplicada por gotejamento (via fertirrigação), a produção de frutos foi 20 a $25 \%$ acima da obtida com aspersão, e 40 a $50 \%$ maior que o tratamento não irrigado. 
McNiesh et al. (1985) relatam que na Costa da Califórnia, EUA, a irrigação por aspersão era tradicionalmente utilizada. Entretanto, nos últimos anos, o método localizado por gotejamento tem sido amplamente adotado. Esta mudança de métodos ocorreu devido a maior eficiência no uso da água e melhoria do controle de problemas fitossanitários.

Voth \& Bringhurst (1990) relatam que o manejo adequado das práticas culturais, aliado ao desenvolvimento de novos cultivares levou ao sucesso no cultivo de morango na Califórnia. Com relação ao sistema de irrigação adotado, os autores ressaltam, como benéfico para a produção, o uso da irrigação por gotejamento por várias razões, entre elas destacam-se: a redução do uso da água e o aumento da produtividade (na ordem de 30 a 50\% nos cultivos de inverno).

Parisot (1990) relata que a irrigação localizada, manejada com tensiômetros, tem sido o método que melhor se adapta ao cultivo do morangueiro na região de "Reunion Island", território francês localizado no Oceano Índico.

Seong et al. (1993) observaram diminuição na incidência do mofocinzento causado por Botrytis cinerea nos frutos do morangueiro com irrigação por gotejamento, quando comparada à irrigação por sulcos. Já com relação à aspersão, Blasse (1977) relatou o aumento da susceptibilidade a essa doença.

O uso do gotejamento no cultivo do morangueiro, além de ser amplamente utilizado nos Estados da Califórnia e da Flórida há vários anos, está se expandindo para outras regiões dos Estados Unidos, como a Carolina do Norte e o Alabama (Himelrick et al., 1993).

Pomares et al. (1994) observaram que, no cultivo do morangueiro no verão, na região de Valencia, na Espanha, a produção foi mais elevada, quando se utilizou a irrigação por gotejamento, se comparada à obtida com irrigação por sulcos. Por outro lado, a produção precoce foi maior com a irrigação por sulcos. 
Passos (1997) realizou quatro experimentos com morangueiro cv. Campinas, em Atibaia, SP, dos quais três foram irrigados por gotejamento e um por aspersão. Nos experimentos irrigados por gotejamento, sendo dois em cultivo protegido, as lâminas de irrigação foram diferentes. A maior lâmina de água, com gotejamento em cultivo protegido, favoreceu os teores de nutrientes nas folhas, a produção dos primeiros meses de colheita e o peso médio dos frutos durante o ciclo. $\mathrm{Na}$ aspersão, os intervalos entre irrigações foram maiores, o desenvolvimento de doenças causadas por fungos foi maior até o início de outubro, e a produção comercial foi reduzida.

Em decorrência dos aspectos negativos e positivos de cada método de irrigação, é necessária a adoção de um manejo adequado de água, que não propicie condições para o aparecimento de problemas fitossanitários.

\subsubsection{Manejo das irrigações}

\subsubsection{Generalidades}

Atualmente, um dos principais problemas no cultivo do morangueiro é o controle fitossanitário. $O$ excesso de água é um dos fatores que propiciam condições favoráveis à manifestação de alguns patógenos.

Segundo Gerhmann (1985), erros no manejo das irrigações podem resultar em sérias reduções na produtividade, por ser o morangueiro sensivel ao estresse hídrico. Por outro lado, irrigações excessivas e um período prolongado de saturação do solo podem propiciar condições favoráveis ao aparecimento de Pythium spp. (Rotem \& Palti, 1969), Rhizoctonia spp. e Phytophthora cactorum (Maas, 1984). Segundo McNiesh et al. (1985), a finalidade principal da irrigação é satisfazer as necessidades hídricas da 
cultura, porém ressaltam que um objetivo secundário importante é manter o solo com boa aeração, e finalmente concluem que erros no manejo da água podem levar à redução da produtividade, por ser o morangueiro sensivel ao excesso e ao déficit hídrico. Segundo Blatt (1984), a irrigação aplicada no momento adequado proporciona aumento no tamanho do fruto e na produção total, mesmo em condições de irrigações complementares às precipitações.

\subsubsection{Sensibilidade ao déficit hídrico}

Segundo Doorenbos \& Pruitt (1984), o período crítico ao déficit hídrico do morangueiro vai do desenvolvimento ao amadurecimento do fruto.

Gehrmann (1985) conduziu experimento com objetivo de estudar o efeito do estresse hídrico no desenvolvimento do morangueiro cv. Korona. Os diferentes níveis de estresse foram induzidos através do fornecimento de 75 , 50 e $25 \%$ do consumo diário de água, sendo que a testemunha recebeu $100 \%$ da necessidade de água. $O$ estresse hídrico teve grande efeito sobre 0 desenvolvimento das plantas. $O$ tratamento que aplicou $100 \%$ da necessidade de água resultou em melhor desenvolvimento das plantas. A produção foi reduzida nos tratamentos com estresse hídrico, ocorrendo diminuição do peso médio e do número de frutos. Nas plantas estressadas, a maturidade dos frutos foi acelerada. O teor de sólidos solúveis totais sob estresse hídrico aumentou.

Klar et al. (1990) observaram que o estresse de água, no florescimento e na frutificação, teve maior efeito na redução da produção, quando comparado ao déficit durante o desenvolvimento vegetativo. A redução na produção foi associada à abscisão de flores e aborto de inflorescências, antes da ântese. Os autores observaram que quanto maior o número de dias de seca menor a produção. $O$ teor de vitamina $C$ do fruto não diferiu nos tratamentos de estresse, nos diferentes estádios da cultura. 
Campos et al. (1992) realizaram experimento em casa de vegetação em Botucatu, Estado de São Paulo, com o objetivo de estudar algumas relações hídricas das plantas e seus aspectos relacionados à resistência à seca nos diferentes estádios de desenvolvimento do morangueiro cv. Campinas. Foram considerados 3 estádios do ciclo da cultura: o desenvolvimento vegetativo, o florescimento e frutificação, e a produção de estolhos. Os vasos não submetidos à seca eram mantidos com irrigação constante por ascenção capilar. Nos tratamentos submetidos à seca, as irrigações eram realizadas somente quando o potencial da água no solo atingia -1,5 MPa. De acordo com os resultados obtidos, a adaptação à seca foi mais proeminente na fase de produção de estolhos, seguida pelo período de desenvolvimento vegetativo, sendo, portanto, a fase de florescimento e frutificação mais sensivel ao déficit hídrico.

Peñuelas et al. (1992) observaram a influência do estresse hídrico leve a moderado, no morangueiro sob cultivo protegido em dois tratamentos, nos quais as irrigações eram realizadas sempre que o potencial matricial de água no solo atingia $-0,01 \mathrm{MPa}$ (tratamento úmido) e -0,07 $\mathrm{MPa}$ (tratamento seco), respectivamente. Para avaliação do estresse hídrico na planta, foi medida a temperatura da folhagem com termômetro infra-vermelho. $O$ estresse hídrico moderado diminuiu a matéria seca, índice de área foliar e produção de frutos. Embora o estresse imposto pelos tratamentos tivesse a intensidade de leve a moderado, foram observadas diferenças significativas na temperatura da folhagem, diferença entre temperatura foliar e do ar, índice de estresse hídrico na cultura (CWSI) e graus dia de estresse (SDD).

Com a finalidade de analisar a influência de diferentes regimes hídricos sobre o crescimento do fruto e da planta, características morfológicas, partição de assimilados, algumas características fisiológicas e evapotranspiração do morangueiro nos cultivares Campinas e AGF 80 , luchi (1993) realizou experimentos em casa de vegetação, em Viçosa, Estado de 
Minas Gerais. Foi avaliado o efeito de diferentes regimes hídricos sobre alguns processos fisiológicos básicos. Os tratamentos constaram dos seguintes niveis de água no solo: capacidade de campo, com potencial de água no solo de -0,01 MPa; estresse hídrico cíclico severo (EHC), com potencial de água no solo de -0,01 a -1,0 MPa; estresse hídrico cíclico severo na frutificação (EHCF), com potencial de água no solo de $-0,01$ a -1,0 $\mathrm{MPa}$; estresse hídrico cíclico moderado (EHM), com potencial de água no solo de $-0,01$ a $-0,40 \mathrm{MPa}$. $\mathrm{O}$ número de folhas, de frutos por planta, o acúmulo de matéria seca e a área foliar foram reduzidos pelo déficit hídrico, sendo mais pronunciado o efeito do estresse no cultivar AGF 80. O déficit hídrico aumentou a resistência estomática, diminuiu a taxa fotossintética líquida e o potencial hídrico foliar. As plantas conduzidas na capacidade de campo, apresentaram maior evapotranspiração, em virtude da maior área foliar associada à disponibilidade de água no solo e à menor resistência estomática, enquanto que as plantas sob estresse hídrico apresentaram menor evapotranspiração. O estresse hídrico cíclico severo diminuiu a taxa fotossintética mais drasticamente que o moderado.

Os mecanismos de adaptação do morangueiro às condições de déficit ocorrem por ajuste osmótico das folhas (O'Neil, 1983) e pelo aumento da resistência estomática (luchi, 1993). Ainda segundo O'Neil (1983), as folhas novas de morangueiro têm maior habilidade de ajuste osmótico do que as folhas velhas. luchi (1993) observou que as folhas velhas que sofreram déficit hídrico periódico entraram em senescência, enquanto que as folhas novas do morangueiro permaneceram verdes.

Observando-se os resultados obtidos em diferentes locais e cultivares, nota-se que o morangueiro é uma planta sensivel ao déficit hídrico, bem como ao excesso de água e à consequente falta de aeração no solo. Portanto, o conhecimento dos principais parâmetros para o manejo racional das irrigações é importante para o desenvolvimento e produção da cultura. 


\subsubsection{Profundidade do sistema radicular}

A profundidade efetiva do sistema radicular é um dos parâmetros básicos necessários para o planejamento e $\circ$ manejo das irrigações. Compreende a camada desde a superfície do solo até onde se concentram a maior parte das raízes absorventes ou finas (Daker, 1988).

O sistema radicular do morangueiro é formado por raízes adventícias e fasciculadas. As raízes primárias, adventícias, são grandes e perenes, com função de órgão de reserva, e também contribuem para absorção de nutrientes pelo contínuo crescimento e pela produção sucessiva de novas radicelas (Martins, 1983). As raízes secundárias ou fasciculadas são longas e se desenvolvem lateralmente ao rizoma, dispostas em camadas superpostas, ficando as camadas mais velhas embaixo das mais novas (Galletta \& Bringhurst, 1990). Dessa forma, o sistema radicular do morangueiro é renovado durante o ciclo da cultura. Conforme as radicelas mais velhas vão morrendo, as mais novas vão se formando em posição superior no rizoma da planta. Devido a essa forma de renovação, as raízes são pouco profundas (Natividade ${ }^{4}$ citado por Inforzatto \& Camargo, 1973).

Nelson \& Wilhem (1957) estudaram o desenvolvimento das raízes de dois cultivares de morango em solo arenoso. As raízes atingiram até $60 \mathrm{~cm}$ de profundidade, com muitas ramificações até essa profundidade. Observaram também que as raízes principais são grandes e perenes e têm função de órgão de reserva, e que as radicelas têm curta duração sendo renovadas frequentemente.

Inforzatto \& Camargo (1973) estudaram o desenvolvimento do sistema radicular do morangueiro, cv. Campinas, no municipio de Campinas, SP. Os resultados mostraram que 73 e $90 \%$ da matéria seca das raízes

\footnotetext{
${ }^{4}$ NATIVIDADE. J.V. Cultura dos morangueiros. Alcobaça. Of. José de Oliveira Jr., 1940. 135p.
} 
situaram-se até $5 \mathrm{~cm}$ de profundidade, respectivamente aos 105 e 201 dias após o plantio. A profundidade máxima atingida pelas raízes foi de $55 \mathrm{~cm}$.

Dwyer et al. (1987) realizaram amostragens do sistema radicular do morangueiro a intervalos semanais em Ottawa, Canadá. A profundidade máxima atingida pelo sistema radicular foi de $60 \mathrm{~cm}$, porém a maior parte se concentrou até $30 \mathrm{~cm}$, sendo esta a profundidade recomendada para fins de manejo das irrigações. Este resultado concorda com o recomendado na literatura internacional por Doorenbos \& Pruitt (1984) e Stanley \& Maynard (1990) e, o utilizado por McNiesh et al. (1985), Strabbioli (1988) e Serrano et al. (1992).

\subsubsection{Manejo da água}

Em experimentação realizada em Piracicaba, SP, Olitta \& Minami (1974) estudaram o efeito de diferentes freqüências de irrigação no morangueiro (1, 2 e 3 dias). Nos diferentes tratamentos a lâmina de água aplicada foi a mesma. Para determinar o fator de ajuste da evaporação do tanque classe $A$, foram instalados tensiômetros, sendo esse controle, entretanto, feito em apenas 1 canteiro. Os autores concluíram que para o gotejamento, o turno de rega de 3 dias proporcionou maiores produções quando comparado a intervalos de 1 e 2 dias. O período de avaliação da produção foi de apenas dois meses.

Olitta (1980) realizou trabalho com morangueiro cultivar $\mathrm{SH}$, para as condições de Piracicaba, SP, visando ao estudo do tipo de canteiro mais adequado para o cultivo, bem como à determinação do fator $f$ para realização do manejo das irrigações, quando se utiliza o tanque classe $A$. O sistema de irrigação utilizado foi o gotejamento. Os resultados indicaram que o melhor tipo 
de canteiro foi o de 2 linhas de plantas. De acordo com os resultados obtidos, o fator de consumo de água $\mathbf{f}$ de 0,8 , em relação à evaporação do tanque classe A foi o que correspondeu a maior produtividade. Este fator variou de 0,5 a 1,0. Entretanto, convém salientar que o tipo de canteiro e o espaçamento foram diferentes dos atualmente utilizados no cultivo do morangueiro.

Giovanardi \& Testolin (1984) observaram o efeito do manejo das irrigações baseadas no consumo de diferentes valores de água disponivel no solo, no cultivo do morangueiro. De acordo com os resultados obtidos, o consumo de $20 \%$ da água disponivel foi o tratamento que proporcionou maior produção de frutos e matéria seca, quando comparado ao consumo de 50 e $80 \%$ da água disponivel.

Dwyer et al. (1987) realizaram estudo de manejo das irrigações no morangueiro por um periodo de três anos em Ottawa, Canadá. Para tanto as plantas foram submetidas a quatros tratamentos, sendo um deles não irrigado. Os outros três tratamentos consistiram de diferentes critérios de manejo das irrigações. Um foi manejado com irrigações diárias, outro através do potencial de água na folha, sempre menor ou igual a -0,25 MPa, e, finalmente, o último tratamento permitindo o consumo de $50 \%$ do armazenamento da água no solo. Todos os tratamentos irrigados alcançaram produtividades significativamente maiores que o não irrigado. Os diferentes critérios de irrigação não tiveram efeito na duração do período de colheita e no peso dos frutos. O manejo pelo potencial de água na folha, foi o critério mais eficiente, no sentido de economia de água. Os autores salientam que, embora não tenham ocorrido diferenças significativas entre os três tratamentos irrigados, o critério de irrigar diariamente apresentou tendência de maior desenvolvimento vegetativo e produção nos 3 anos estudados.

Strabbioli (1988) avaliou o efeito de diferentes manejos de irrigação no morangueiro em Roma, Itália. Durante os primeiros 15 dias as irrigações foram por aspersão, a partir desta data utilizou-se o gotejamento. A 
evapotranspiração da cultura foi estimada com base na evaporação do tanque classe $A$, considerando um coeficiente de cobertura relativo ao diâmetro da copa e estádio da cultura. Os diferentes tratamentos de irrigação foram estabelecidos multiplicando-se a evapotranspiração da cultura por 4 coeficientes: 0,$33 ; 0,66 ; 1,00$ e 1,33. Em todos os tratamentos, as irrigações foram realizadas sempre que evaporado $10 \mathrm{~mm}$ de água. Apesar dos diferentes coeficientes assumidos, os resultados de produção, tamanho e número de frutos por planta não apresentaram diferenças significativas. O autor relata que, tal fato pode ter ocorrido devido às elevadas precipitações observadas durante a experimentação.

Visando à determinação do coeficiente de cultura $(\mathrm{kc})$, McNiesh et al. (1985) realizaram estudos na costa da California. Os coeficientes de cultura foram estimados com relação à evapotranspiração de referência (ETo) e à evaporação do tanque classe $A(E C A)$. Os valores de $k c$ obtidos relacionados com a ETo variaram de 0,45 a 0,70 , no ciclo da cultura. Já para o tanque classe A oscilaram entre 0,55 e 0,80 .

Para as condições de Bolonha, na Itália, Rossi Pisa et al. (1989) determinaram valores de kc para o morangueiro cv. Fern (neutro ao fotoperiodismo), por meio de lisimetros. Em dois tratamentos foi utilizada a irrigação localizada por gotejamento. Nestes dois tratamentos a água foi aplicada a partir da evaporação do tanque classe A (ECA e ECA/2). Em um terceiro tratamento a irrigação foi realizada por subirrigação. Os tratamentos irrigados por gotejamento tiveram produções semelhantes ou maiores que as observadas com a subirrigação. Os valores de kc variaram de 0,2 a 0,8, durante o ciclo, considerando todos os tratamentos, situando-se a maior parte do tempo entre 0,5 e 0,6 . 
No manejo das irrigações do morangueiro no verão, na Espanha, Pomares et al. (1994) adotaram 0,7 como coeficiente de cultura, sendo a evaporação estimada com tanque classe $\mathrm{A}$. Com o manejo adotado, o intervalo entre irrigações variou de 1 a 3 dias.

O manejo das irrigações no morangueiro pode ser realizado por meio de tensiômetros que, medindo o potencial matricial de água no solo, determina o momento das irrigações, e ainda podem auxiliar no ajuste da lâmina de irrigação. Martins (1983) realizou irrigações por sulcos no morangueiro, sempre que o potencial matricial de água no solo atingia $-0,070$ MPa, em Viamão, RS. Por outro lado, para determinar o momento das irrigações no morangueiro, vários autores utilizam ou recomendam valores de potencial de -0,02 a -0,04 MPa, em diferentes regiões, situações de cultivo, solo e clima (Haise \& Hagan, 1967; McNiesh et al., 1985; Goulart \& Funt, 1986 e Strabbioli, 1988).

Serrano et al. (1992) estudaram o efeito de quatro níveis de água no solo, sobre a produção de frutos, eficiência do uso da água, e a função de produção, para o cultivar Chandler, nas condições da Catalunha, Espanha. As plantas foram cultivadas no campo e em lisímetros de drenagem. As irrigações foram realizadas sempre que o potencial matricial de água no solo atingia $-0,01 ;-0,03 ;-0,05$ e $-0,07 \mathrm{MPa}$. A produção máxima foi obtida no tratamento mais úmido $(-0,01 \mathrm{MPa})$. A queda da produção nos demais tratamentos foi associada à redução na taxa de assimilação total, decorrente do decréscimo na área foliar.

De acordo com os vários trabalhos desenvolvidos no Brasil e em diferentes locais no mundo, observa-se que o morangueiro é uma planta que responde bem à irrigação. Entretanto, além do uso da irrigação, necessária se faz a adoção do manejo adequado de água, para que esta não tenha efeitos nocivos ao desenvolvimento, sanidade e produção das plantas. 


\section{MATERIAL E MÉTODOS}

\subsection{Local, clima e período de experimentação}

Foram realizados dois experimentos com morangueiro, um em cultivo protegido e outro a campo aberto, no Sítio São João, localizado no bairro Campo dos Aleixos, no município de Atibaia, principal produtor de morango do Estado de São Paulo (Secretaria da Agricultura e Abastecimento de São Paulo, 1996). As coordenadas geográficas são: latitude $25^{\circ} 07^{\prime}$, longitude $46^{\circ} 50^{\prime} \mathrm{W}$ e altitude $744 \mathrm{~m}$ (Alfonsi ${ }^{5}$ ).

O clima da região é do tipo $\mathrm{Cfa}$, segundo a classificação de Köppen sendo subtropical de altitude, com verão quente (temperatura média do mês mais quente acima de $22^{\circ} \mathrm{C}$ ), sem estação seca pronunciada. Na Figura 1 estão apresentados os valores médios mensais de precipitação e evapotranspiração potencial (segundo o método de Thornthwaite), de 20 anos, em Atibaia, SP. Os totais de precipitação diminuem de abril a setembro, chegando a ser inferiores à evapotranspiração potencial mensal. Este período, coincide com grande parte do ciclo produtivo do morangueiro. Devido à sensibilidade da cultura, ao estresse hídrico e à irregularidade na distribuição das chuvas, a irrigação tem sido prática imprescindível no cultivo de morangueiro no Estado de São Paulo.

\footnotetext{
${ }^{5}$ ALFONSI. R. R. (IAC. Seção de Climatologia Agricola. Campinas) Comunicação pessoal. 1996.
} 


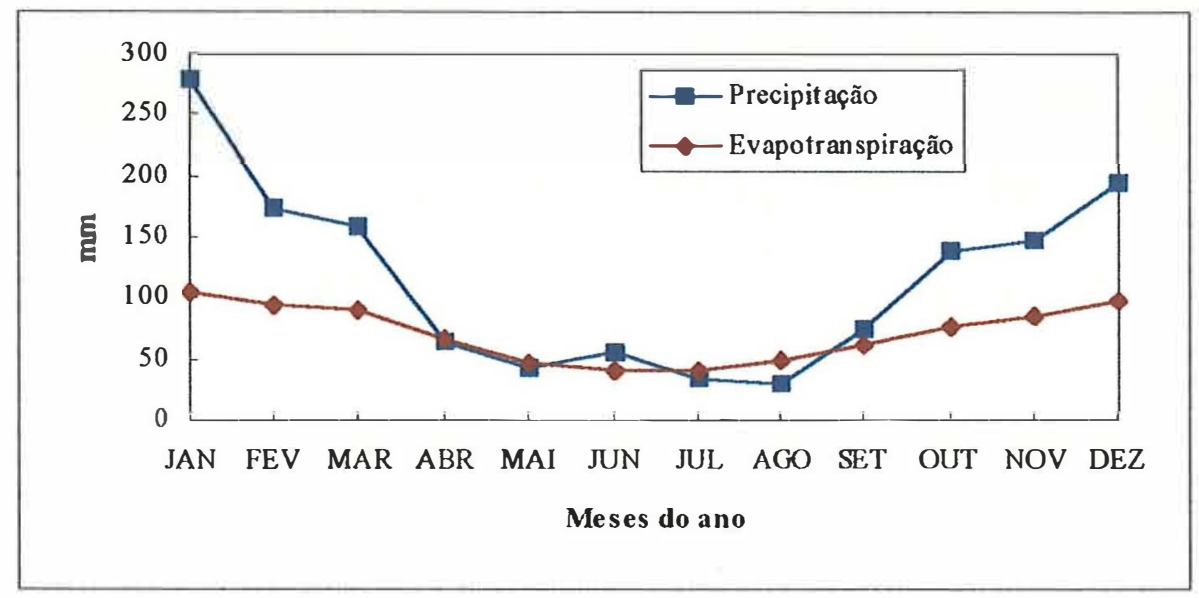

Figura 1 - Valores médios mensais de precipitação pluvial $(\mathrm{mm})$ e de evapotranspiração potencial, ETP $(\mathrm{mm})$, ocorridos em 20 anos no município de Atibaia, SP. Dados fornecidos pela Seção de Climatologia Agrícola do Instituto Agronômico de Campinas.

Os experimentos foram iniciados em 20 de abril de 1995, com o transplantio das mudas, e finalizados em 22 de dezembro do mesmo ano, quando se realizou a última colheita de frutos.

\subsection{Solo}

Os resultados de granulometria, densidade real e porosidade do solo nas camadas de 0-20 cm, 20-40 cm e 40-60 cm encontram-se na Tabela 1. A amostra de solo foi composta de 40 sub-amostras coletadas ao acaso na área dos dois experimentos. A metodologia de separação das frações do solo foi realizada pelo método da "pipeta", modificado por Grohmann \& Raij (1974), e dispersão com $\mathrm{NaOH}$ a $0,1 \mathrm{~N}$. O solo foi classificado como Latossolo Vermelho Amarelo, textura argilosa (Medina \& Grohmann, 1967). Foram retiradas amostras indeformadas, com anéis de $5 \mathrm{~cm}$ de diâmetro e $3 \mathrm{~cm}$ de altura, para determinação da densidade do solo e confecção da curva característica de retenção de água no solo representativa da área dos 
experimentos, em canteiros, com sete repetições. Os resultados de densidade do solo se encontram na Tabela 1. Para a curva de retenção, as amostras foram retiradas a $10 \mathrm{~cm}$ de profundidade. As determinações foram realizadas no Laboratório de Física de Solo do Departamento de Engenharia Rural da ESALQ/USP. Foi utilizada mesa de tensão, para determinação da umidade do solo nos potenciais de água no solo de -0,001, -0,002 e -0,004 MPa, e câmara de pressão de Richards, para os potenciais de $-0,01,-0,035,-0,050,-0,070$, $-0,100,-0,500$ e $-1,500 \mathrm{MPa}$. A curva de retenção de água no solo se encontra na Figura 2.

Tabela 1 - Características físicas do Latossolo Vermelho Amarelo, textura argilosa, em Atibaia, SP, onde se realizaram os experimentos.

\begin{tabular}{cccccccc}
\hline Profundidade & \multicolumn{9}{c}{ Composisão granulométrica $(\%) \mathrm{a}^{*}$} & \multicolumn{2}{c}{ Densidade } & Porosidade \\
& \multicolumn{2}{c}{ Areia } & Areia & solo real & \\
$(\mathrm{cm})$ & grossa & fina & Silte & Argila & $\left(\mathrm{g} / \mathrm{cm}^{3}\right)$ & $(\%)$ \\
\hline $0-20$ & 21,4 & 25,3 & 7,9 & 45,4 & 1,13 & 2,20 & 48,6 \\
$20-40$ & 24,1 & 24,9 & 2,9 & 48,1 & 1,15 & 2,22 & 48,5 \\
$40-60$ & 18,1 & 28,4 & 4,8 & 48,7 & 1,12 & 2,17 & 48,7 \\
\hline
\end{tabular}

a/ Dimensões das frações do solo $(\mathrm{mm})$ : areia grossa de 2 a 0,20 ; areia fina de 0,20 a 0,02 ; silte de 0,02 a 0,002 e argila $<$ de que 0,002 .

$\mathrm{Na}$ Tabela 2 encontram-se os resultados da análise química do solo, relativos a amostras coletadas, antes do plantio. A análise química do solo foi realizada segundo metodologia descrita por Raij \& Zullo (1977).

No preparo do solo, foram realizadas duas subsolagens, seguidas de passagem de enxada rotativa, e finalmente do encanteirador. 


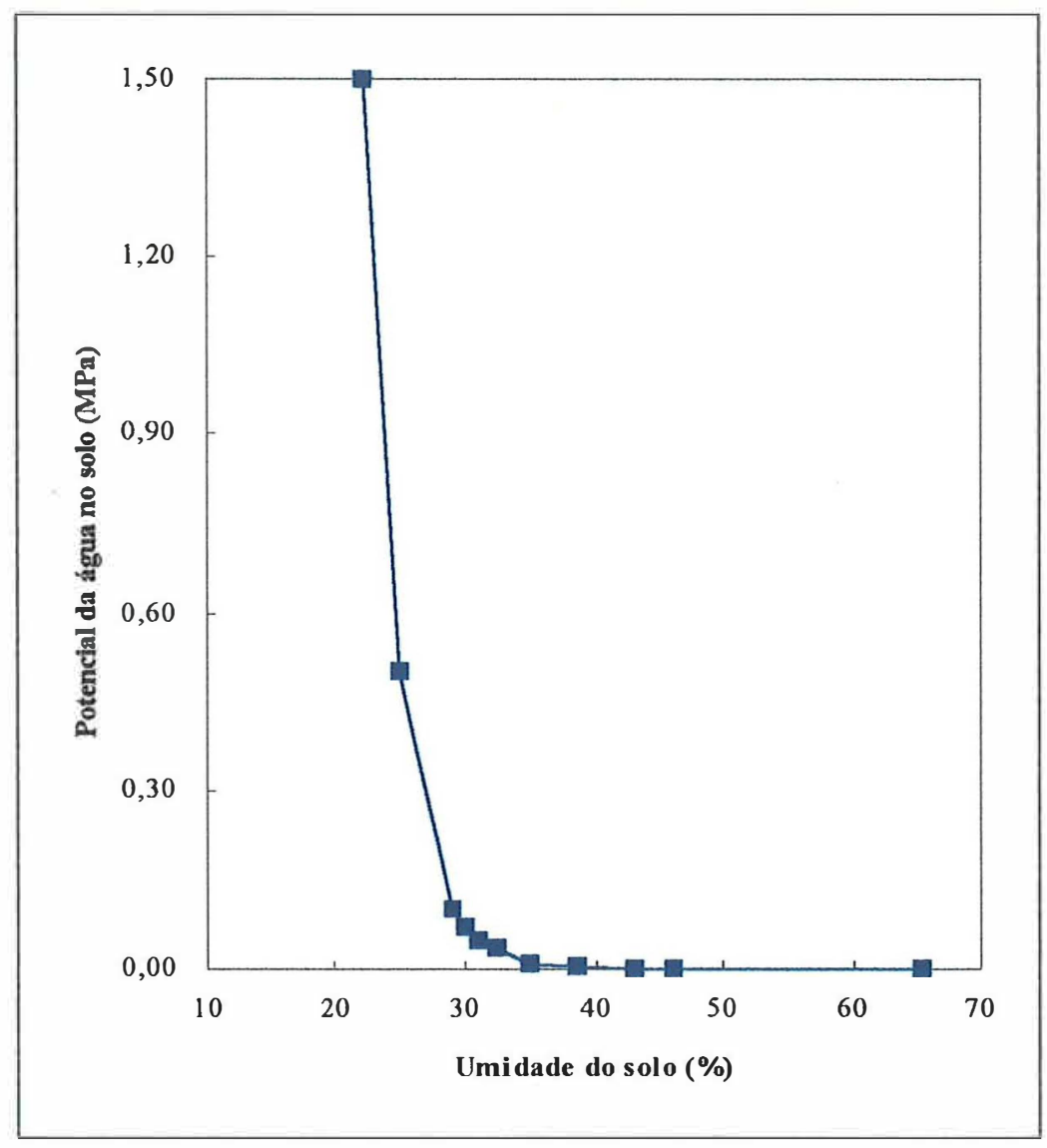

Figura 2 - Curva característica de retenção de água no solo na área experimental.

O solo do experimento foi desinfestado com Bromex (produto composto por $98 \%$ de brometo de metila e $2 \%$ de cloropicrina), na dosagem de $100 \mathrm{~cm}^{3}$ por $\mathrm{m}^{3}$ de solo. Para o cálculo do volume, consideraram-se os primeiros $30 \mathrm{~cm}$ de profundidade do solo, correspondendo aproximadamente à altura dos canteiros. O produto foi aplicado sob cobertura plástica, a qual foi retirada após 48 horas. A desinfestação do solo foi realizada no dia 10 de abril. Antes do plantio, o solo permaneceu descoberto por mais de 7 dias para aeração, conforme recomendado por Kimati (1995). A desinfestação do solo foi realizada com o objetivo de controlar plantas invasoras, que certamente se desenvolveriam sob o plástico transparente, e, principalmente, para controle de 
fungos patogênicos de solo, uma vez que a área já havia sido cultivada com morangueiro em anos anteriores (Larson \& Shaw, 1995).

Tabela 2 - Análise química do Latossolo Vermelho Amarelo, textura argilosa, realizada antes do plantio.

\begin{tabular}{rccccccccc}
\hline $\begin{array}{c}\text { Prof. } \\
\text { (cm) }\end{array}$ & $\begin{array}{c}\mathrm{pH} \\
\mathrm{CaCl}_{2}\end{array}$ & $\begin{array}{c}\mathrm{M} . \mathrm{O} \\
(\%)\end{array} \mathrm{a}^{*}$ & $\begin{array}{c}\mathrm{P} \\
\mathrm{mg} / \mathrm{dm}^{3}\end{array}$ & $\mathrm{~K}$ & $\mathrm{Ca}$ & $\mathrm{Mg}$ & $\mathrm{H}+\mathrm{Al}$ & $\mathrm{T}$ & $\mathrm{V}$ \\
$-0-20$ & 5,9 & 3,1 & 142,5 & 0,29 & 5,8 & 1,1 & 1,3 & 8,5 & 84,7 \\
$20-40$ & 5,5 & 2,8 & 58,5 & 0,46 & 3,5 & 0,9 & 1,8 & 6,7 & 73,0 \\
\hline
\end{tabular}

$\mathrm{a}^{\star}$ teor em porcentagem equivale a g/dm ${ }^{3}$ dividido por 10 .

$\mathrm{b}^{*}$ meq/100 $\mathrm{cm}^{3}$ equivale a $\mathrm{mmol}_{d} / \mathrm{dm}^{3}$ dividido por 10 .

\subsection{Delineamento experimental e análise dos dados}

Os dois experimentos realizados foram implantados em esquema fatorial $2 \times 3$ (coberturas do solo e niveis de irrigação), em blocos ao acaso, com 5 repetições, totalizando 30 parcelas em cada um. Um dos experimentos foi instalado em condições de campo aberto, como é normalmente cultivado o morangueiro no Brasil, e o outro em ambiente protegido. As plantas foram cultivadas em canteiros com 1,2 m de largura, no espaçamento de 0,30 x 0,30 m. No campo aberto, as parcelas constaram de canteiros com $18 \mathrm{~m}$ de comprimento e 1,2 m de largura; e no cultivo protegido, cada parcela teve 5,1 m de comprimento. Cada parcela no campo aberto tinha 240 plantas, e no cultivo protegido 68 plantas. A diferença no tamanho das parcelas, nos dois experimentos, ocorreu apenas porque no campo aberto havia quatro subparcelas para amostragem de plantas para determinação de matéria seca ao longo do ciclo da cultura. As parcelas para avaliação da produção foram idênticas nos dois experimentos, constando de 40 plantas $\left(3,6 \mathrm{~m}^{2}\right)$. A área experimental no campo aberto foi de $943,5 \mathrm{~m}^{2}(37 \times 25,5 \mathrm{~m})$, e no cultivo protegido foi de $350 \mathrm{~m}^{2}(7 \times 50 \mathrm{~m})$. 
Os resultados referentes a produção, teor de nutrientes nas folhas, comprimento de raiz por volume de solo, desenvolvimento vegetativo e incidência de doenças foram submetidos à análise de variância, com teste $F$, em cada ambiente estudado, separadamente. As médias foram comparadas pelo teste de Tukey, ao nível de $5 \%$ de probabilidade. Com relação ao sistema radicular, foi realizada análise de variância para cada camada de profundidade estudada separadamente $(0-10,10-20,20-30,30-40,40-50,50-60 \mathrm{~cm})$.

Para análise das variáveis em diversas épocas, durante o ciclo (desenvolvimento vegetativo, produção e incidência de doenças), utilizou-se 0 delineamento de tratamentos de parcela sub-dividida.

Foram estimadas correlações simples entre as variáveis índice de área foliar, matéria seca da parte aérea e radicular, nas determinações realizadas no final dos experimentos (22/12/95), nos dois ambientes de cultivo. As estimativas das correlações foram submetidas ao teste $t$ a $5 \%$ de probabilidade.

Os dados de temperatura do solo e resistência estomática, nos diferentes tratamentos, foram submetidos à análise de intervalos de confiança, conforme Snedecor \& Cochran (1973), utilizando o teste $t$ a $5 \%$ de probabilidadè.

\subsection{Cultivar e época de plantio}

O cultivar utilizado foi o Campinas IAC-2712, o mais plantado no Estado de São Paulo para consumo "in natura". Esse cultivar, lançado na década de 60, foi obtido do cruzamento dos cultivares americanos Donner e Tahoe (Camargo \& Passos, 1993).

O plantio das mudas foi realizado nos dias 20 e 21 de abril de 1995, dentro da época recomendada para o morangueiro no Estado de São 
Paulo, conforme Passos et al. (1998). As mudas utilizadas foram produzidas no próprio Sítio São João, onde se realizaram os experimentos.

\subsection{Coberturas de solo}

Como coberturas de solo foram utilizados filmes de polietileno de baixa densidade (PEBD), preto e transparente. O plástico preto (PP) tinha espessura de 30 micras. O plástico transparente (PT) utilizado no cultivo protegido tinha 50 micras de espessura, e no campo aberto 150 micras. Devido à escassez de filme de polietileno transparente (PT) de 50 micras, no local da experimentação, utilizaram-se filmes de espessuras diferentes nos experimentos. O plástico preto é a cobertura de solo mais utilizada no Estado de São Paulo (Groppo \& Tessarioli Neto, 1991), e o transparente tem sido utilizado com sucesso para vários cultivares e locais (Voth, 1972; Voth \& Bringhurst, 1990).

No experimento a campo aberto, as coberturas de solo foram instaladas em 24 de maio, e no cultivo protegido no dia 1 de junho.

\subsection{Irrigação}

Até o dia 10 de maio, fase de pegamento das mudas, as irrigações foram realizadas por aspersão, parceladas de 2 a 6 vezes ao dia.

Em 26 de abril, foram instaladas duas estações tensiométricas, no campo e no cultivo protegido, com dois tensiômetros cada uma, visando o monitoramento das irrigações até o início dos tratamentos de níveis de água. Nesse período, as irrigações eram realizadas sempre que o potencial de água no solo atingia $-0,01 \mathrm{MPa}$ a $10 \mathrm{~cm}$ de profundidade. 
O sistema de irrigação por gotejamento foi instalado em 10 de maio. Foi utilizado o tubo gotejador "Super Typhoon 125", da Netafim, com diâmetro interno de 15,9 mm, com gotejadores espaçados em 0,3 m e com vazão de $1,74 \mathrm{l} / \mathrm{h}$. Foram colocadas duas linhas de tubo gotejadores sobre cada canteiro com quatro fileiras de plantas, cada linha entre duas fileiras de plantas, exceto a central. Foram estimados os coeficientes de uniformidade de aplicação de água, conforme Keller \& Karmeli (1974). Para os dois ambientes estudados, o valor desse coeficiente foi de $93 \%$. Após esse teste, foram colocadas as coberturas do solo sobre os canteiros.

A partir de 12 e 13 de junho, os níveis de água foram diferenciados. Utilizaram-se três níveis de potencial de água no solo, para determinação do momento das irrigações, correspondendo a -0,010 ( $\left.\mathbf{N}_{1}\right)$, $-0,035\left(N_{2}\right)$ e $-0,070\left(N_{3}\right) \mathrm{MPa}$, medidos em tensiômetros instalados a $10 \mathrm{~cm}$ de profundidade. Em cada combinação de cobertura do solo e nível de irrigação, foram instaladas três estações tensiométricas, sendo duas delas com tensiômetros a 10 e a $20 \mathrm{~cm}$ de profundidade, e uma terceira com cinco tensiômetros instalados nas profundidades de 10,20,30, 40 e $50 \mathrm{~cm}$. Os tensiômetros instalados de 20 a $50 \mathrm{~cm}$ de profundidade tiveram a função de monitorar a frente de molhamento no perfil do solo, e auxiliar o ajuste das lâminas de irrigação.

As irrigações foram realizadas até o dia 22 de dezembro. Foram contabilizadas as lâminas, o número de irrigações, e calculada a freqüência de ocorrência dos intervalos entre irrigações, ocorridos nos diferentes níveis de irrigação, de forma similar aos procedimentos de Pires \& Arruda (1995), nos dois ambientes estudados (campo aberto e cultivo protegido). 


\subsection{Cultivo protegido}

Para o experimento realizado em cultivo protegido foi construída uma estufa modelo capela, de madeira, com $7 \mathrm{~m}$ de largura e $50 \mathrm{~m}$ de comprimento, coberta com filme de polietileno de baixa densidade, transparente, com espessura de 100 micra. O maior lado da estufa ficou orientado no sentido noroeste-sudeste. A altura máxima da estufa no centro foi de $3,0 \mathrm{~m}$, e nas laterais foi de $2,15 \mathrm{~m}$. As laterais da estufa foram protegidas até $0,75 \mathrm{~m}$ de altura e, o restante, $1,4 \mathrm{~m}$, mantido totalmente aberto durante os dias sem chuva. Em caso de precipitação, as cortinas foram fechadas. A manutenção das janelas abertas, sempre que possível, teve o objetivo de permitir melhor ventilação, para evitar a ocorrência de aumento excessivo da temperatura e umidade relativa do ar, condições desfavoráveis para a produção de frutos, e favoráveis ao desenvolvimento de algumas doenças (Maas, 1984). As parcelas foram instaladas paralelamente ao maior lado da estufa. Ao redor da estufa foi aplicado filme plástico até $70 \mathrm{~cm}$ de profundidade, para evitar a entrada de água de chuva em seu interior.

O cultivo protegido teve como objetivo principal proteger as plantas das precipitações, e dessa forma, permitir o estudo do comportamento fitossanitário, o desenvolvimento das plantas e a produção, nessas condições em Atibaia, SP.

\subsection{Condução da cultura}

Antes do plantio, não foram realizadas calagem e adubação, uma vez que os resultados da análise química do solo (Tabela 2) interpretados segundo Raij et al. (1996), revelaram teores de nutrientes em níveis altos a muito altos. 
As mudas utilizadas no plantio foram enviveiradas no dia 28 de março de 1995, em solo previamente desinfestado, no espaçamento de $5 \mathrm{x}$ $15 \mathrm{~cm}$ (133 mudas $/ \mathrm{m}^{2}$ ), conforme recomendação de Passos et al. (1998). O enviveiramento foi realizado para proporcionar maior enraizamento das mudas, e reduzir o estresse no transplante.

Com o objetivo de uniformizar as plantas utilizadas nos experimentos, escolheram-se mudas de estolho de tamanho médio, para o plantio. Para caracterização das mudas utilizadas no plantio, foram selecionadas 25 delas ao acaso. Obtiveram-se os seguintes resultados (média e desvio padrão da média): número de folhas $4,2 \pm 1,2$; comprimento máximo da parte aérea $18,3 \pm 3,3 \mathrm{~cm}$; comprimento máximo do sistema radicular 17,8 \pm $4,8 \mathrm{~cm}$; matéria seca da parte aérea $1,57 \pm 1,01 \mathrm{~g}$; matéria seca radicular 0,69 $\pm 0,51 \mathrm{~g}$, e área foliar $187,0 \pm 104,9 \mathrm{~cm}^{2}$.

Realizou-se o plantio em canteiros com 0,30 m de altura e 1,20 m de largura, separados entre si por 0,50m, utilizando-se o espaçamento de 0,30 x 0,30 m, segundo recomendação de Passos et al. (1998).

As adubações em pós-plantio foram iguais nos dois experimentos, sendo realizadas em cobertura e via fertirrigação, nos meses de maio, junho e agosto, de acordo com o que normalmente é recomendado para a cultura (Passos, et al., 1998). A partir daí, as adubações nos experimentos foram suspensas, em função dos resultados observados nas análises foliares realizadas a cada 45 dias.

Os frutos foram colhidos manualmente, com pedicelo curto, de junho até dezembro, sempre que $75 \%$ de sua superfície estavam avermelhados. 


\subsection{Medidas físicas do ambiente}

Para a determinação da temperatura do solo, sob as duas coberturas plásticas, nos diferentes níveis de água no solo, foram instalados termógrafos, nos dois experimentos, sem repetição. Os sensores foram instalados a $5 \mathrm{~cm}$ de profundidade, entre as linhas centrais de plantas nas parcelas. Para avaliação das temperaturas do solo, foram determinadas as temperaturas máximas diárias, ocorridas em períodos variáveis, conforme a disponibilidade dos dados, uma vez que houve problemas funcionais nos equipamentos.

Em abrigos meteorológicos, localizados a aproximadamente $15 \mathrm{~m}$ de distância do experimento a campo aberto, e no centro da estufa, no cultivo protegido, foram instalados termohigrógrafos. No campo aberto também foram instalados pluviômetro e tanque classe $\mathrm{A}$.

A temperatura média do ar foi determinada pela média das leituras obtidas de 2 em 2 horas no decorrer do dia, registradas pelo termohigrógrafo.

Os valores diários das temperaturas máximas, mínimas e médias do ar ocorridas, nos dois experimentos, foram agrupadas em períodos de 10 a 11 dias, e encontram-se nas Tabelas 3 e 4, para o cultivo protegido e campo aberto, respectivamente. No campo aberto, além das temperaturas do ar, a Tabela 4 apresenta médias da evaporação do tanque classe A (ECA), e os totais de precipitação por período. 
Tabela 3 - Valores médios de temperatura máxima, mínima e média do ar, em ${ }^{\circ} \mathrm{C}$, ocorridos no período de 19 de maio a 22 de dezembro de 1995 , sob cultivo protegido, em Atibaia, SP.

\begin{tabular}{|c|c|c|c|}
\hline \multirow[t]{2}{*}{ Período } & \multicolumn{3}{|c|}{ Temperatura $a^{\circ} \mathrm{C}$} \\
\hline & Máxima & Mínima & Médi a a* \\
\hline 19 a 31/05 & 22,7 & 9,9 & 15,5 \\
\hline 01 a 10/06 & 24,8 & 7,3 & 14,4 \\
\hline 11 a 20/06 & 22,9 & 8,9 & 14,6 \\
\hline 21 a 30/06 & 23,6 & 11,4 & 16,3 \\
\hline 01 a 10/07 & 23,4 & 11,6 & 16,5 \\
\hline 11 a $20 / 07$ & 26,7 & 11,4 & 17,5 \\
\hline 21 a $31 / 07$ & 27,7 & 10,6 & 17,6 \\
\hline 01 a 10/08 & 26,5 & 11,8 & 17,5 \\
\hline 11 a 20/08 & 28,6 & 11,8 & 18,7 \\
\hline 21 a $31 / 08$ & 30,8 & 10,5 & 19,5 \\
\hline 01 a 10/09 & 28,7 & 9,7 & 18,1 \\
\hline 11 a 20/09 & 26,3 & 13,1 & 18,4 \\
\hline 21 a 30/09 & 25,7 & 15,0 & 19,0 \\
\hline 01 a 10/10 & 28,9 & 14,6 & 20,3 \\
\hline 11 a $20 / 10$ & 25,3 & 14,1 & 20,9 \\
\hline 21 a $31 / 10$ & 27,9 & 11,8 & 19,8 \\
\hline 01 a 10/11 & 30,9 & 15,2 & 21,9 \\
\hline 11 a 20/11 & 26,7 & 14,9 & 20,1 \\
\hline 21 a $30 / 11$ & 29,4 & 14,4 & 20,3 \\
\hline 01 a 10/12 & 29,8 & 15,2 & 21,3 \\
\hline 11 a $22 / 12$ & 28,4 & 16,8 & 21,4 \\
\hline
\end{tabular}

$a^{*}$ Valores estimados pela média das leituras obtidas de duas em duas horas no decorrer do dia. 
Tabela 4 - Valores médios de temperatura máxima, mínima e média do ar, em ${ }^{\circ} \mathrm{C}$ e evaporação de tanque classe $\mathrm{A}$, ECA em $\mathrm{mm}$, e totais de precipitação, em mm, ocorridos desde 20 de abril até 22 de dezembro de 1995, no cultivo a campo aberto, em Atibaia, SP.

\begin{tabular}{|c|c|c|c|c|c|}
\hline \multirow[t]{2}{*}{ Período } & \multicolumn{3}{|c|}{ Temperatura $\left({ }^{\circ} \mathrm{C}\right)$} & \multirow{2}{*}{\multicolumn{2}{|c|}{$\begin{array}{l}\text { ECA Precipitação } \\
\mathrm{mm}\end{array}$}} \\
\hline & Máxima & Mínima & Média $a^{*}$ & & \\
\hline 20 a 30/04 & -- & $-\cdots$ & -- & -- & 6,2 \\
\hline 01 a 10/05 & -- & --- & -- & -- & 44,0 \\
\hline 11 a $20 / 05$ & $-\cdots$ & --- & -- & $\cdots$ & 0 \\
\hline 21 a $31 / 05$ & 22,3 & 11,0 & 16,0 & -- & 0 \\
\hline 01 a 10/06 & 24,6 & 9,2 & 16,1 & -- & 0 \\
\hline 11 a $20 / 06$ & 23,4 & 11,2 & 16,5 & -- & 28,1 \\
\hline 21 a $30 / 06$ & 22,0 & 11,6 & 15,9 & -- & 20,4 \\
\hline 01 a 10/07 & 22,1 & 12,1 & 16,5 & 3,5 & 66,6 \\
\hline 11 a $20 / 07$ & 24,6 & 11,6 & 16,9 & 3,4 & 0 \\
\hline 21 a $31 / 07$ & 26,2 & 10,6 & 17,8 & 4,5 & 25,0 \\
\hline 01 a 10/08 & 25,3 & 11,6 & 17,8 & 4,6 & 7,6 \\
\hline 11 a $20 / 08$ & 27,4 & 12,6 & 19,3 & 4,4 & 0 \\
\hline 21 a $31 / 08$ & 29,5 & 10,7 & 19,6 & 4,0 & 0 \\
\hline 01 a 10/09 & 27,2 & 10,0 & 18,0 & 4,4 & 0 \\
\hline 11 a $20 / 09$ & 25,6 & 13,6 & 18,8 & 4,3 & 10,4 \\
\hline 21 a $30 / 09$ & 23,6 & 14,5 & 18,3 & 4,0 & 77,4 \\
\hline 01 a $10 / 10$ & 28,5 & 15,8 & 20,8 & 3,7 & 8,0 \\
\hline 11 a $20 / 10$ & 24,2 & 15,4 & 19,1 & 4,5 & 176,4 \\
\hline 21 a $31 / 10$ & 27,0 & 13,3 & 21,7 & 5,2 & 81,4 \\
\hline 01 a $10 / 11$ & 29,7 & 16,9 & 23,0 & 3,6 & 8,0 \\
\hline 11 a $20 / 11$ & 26,0 & 16,3 & 20,3 & 5,4 & 24,6 \\
\hline 21 a $30 / 11$ & 28,1 & 15,1 & 20,0 & 4,5 & 46,6 \\
\hline 01 a $10 / 12$ & 28,8 & 16,2 & 21,6 & 5,4 & 21,8 \\
\hline 11 a $22 / 12$ & 27,8 & 17,4 & 22,0 & 5,1 & 111,0 \\
\hline
\end{tabular}

$\mathrm{a}^{*}$ Valores estimados pela média das leituras obtidas de duas em duas horas no decorrer do dia. 


\subsection{Avaliação do teor de nutrientes nas folhas}

As amostras de folhas para avaliação do estado nutricional das plantas, foram retiradas por parcela, durante a $2^{\mathrm{a}}$ florada, aos 131 e 152 dias após o transplantio, no campo aberto, e no cultivo protegido, respectivamente. As análises foram realizadas na Seção de Fertilidade do Solo e Nutrição de Plantas do IAC. O critério de amostragem das folhas seguiu as recomendações de Trani et al. (1983), coletando-se a terceira folha expandida, a partir do ápice. Os limbos foliares foram lavados com água destilada e desmineralizada, secos em estufa a $70^{\circ} \mathrm{C}$ e moídos, sendo analisados quimicamente para determinação dos teores de $\mathrm{N}, \mathrm{P}, \mathrm{K}, \mathrm{Ca}, \mathrm{Mg}, \mathrm{B}, \mathrm{Zn}, \mathrm{Mn}, \mathrm{Fe}$ e $\mathrm{Cu}$, conforme Bataglia et al. (1983).

\subsection{Avaliação da sanidade das plantas}

As avaliações relativas a doenças ocorridas nas plantas dos experimentos foram realizadas com o apoio da Seção de Fitopatologia do IAC.

Nas plantas doentes levadas para identificação dos patógenos em laboratório, inicialmente foi eliminado, o excesso de solo aderido às raízes. Em seguida, o material foi examinado em microscópio estereoscópico, para observação de sintomas que permitissem a identificação de fungos e 0 diagnóstico da doença. Posteriormente, as plantas foram lavadas em água corrente e os rizomas cortados no sentido longitudinal para observar a ocorrência de lesões e necroses. Desse material, parte foi incubado em câmara úmida, dentro de caixas gerbox forradas com papel mata-borrão, umedecido com água destilada esterilizada, aí permanecendo por 3 a 4 dias, em temperatura ambiente de laboratório. Para isolamento de fungos patogênicos foi destinada uma amostra de plantas doentes, das quais foram retirados 
pequenos segmentos de tecidos lesionados, desinfetados superficialmente em solução etanólica a $70 \%$, por um minuto, e solução de hipoclorito de sódio a $1 \%$, por 1 a 2 minutos, dependendo da espessura do tecido analisado. Posteriormente, foram colocados, equidistantemente, 5 segmentos por placa de Petri, sobre superfície de meio BDA (200g batata, $20 \mathrm{~g}$ dextrose, $20 \mathrm{~g}$ ágar e 1 litro de água), procedendo-se à incubação a $28^{\circ} \mathrm{C}$, no escuro, em período de 5 a 8 dias.

Antes do plantio definitivo no campo, algumas mudas apresentaram sintomas de avermelhamento e necrose nas raízes. No sintoma de avermelhamento foi isolada Rhizoctonia solani, com baixo nivel de ocorrência. Já no sintoma de necrose nas raízes, o fungo isolado foi o Fusarium spp., que ocorrendo isoladamente, pode não trazer problemas para o morangueiro durante o ciclo (Tanaka et al., 1995).

No cultivo a campo aberto a identificação do patógeno Xanthomonas fragariae, causador da mancha angular, foi realizada por meio de sintomas visuais (Maas, 1984) e isolamento em meio de cultura. A incidência de mancha de micosferela foi avaliada visualmente.

Para avaliar a ocorrência de doenças no cultivo protegido, realizaram-se duas avaliações, em outubro, contabilizando-se o número de plantas com sintoma de murcha e/ou subdesenvolvimento por parcela. Nesse mesmo mês, foi realizada amostragem de plantas para identificação dos patógenos presentes nesse ambiente de cultivo.

No campo aberto, não foi realizada a contagem de plantas doentes por parcela, uma vez que a ocorrência, embora alta, era homogênea na área do experimento. Entretanto, em novembro, foram coletadas plantas doentes para identificação dos patógenos, associados a seus sintomas visuais, de forma similar ao descrito por Passos (1997).

Ao final do experimento, no cultivo protegido, as doenças foram quantificadas, segundo o seguinte critério: considerou-se, com incidências alta 
$(A)$, média $(M)$ ou baixa $(B)$, as parcelas que apresentavam mais de $66 \%$, de 33 a $66 \%$, e menos de $33 \%$ das plantas com sintomas de murcha e/ou subdesenvolvimento, respectivamente.

\subsection{Avaliação do desenvolvimento vegetativo}

Para avaliação do desenvolvimento vegetativo, foram realizadas várias amostragens de plantas, por ocasião das floradas, e no final do ciclo, após a última colheita, no campo aberto e no cultivo protegido.

\subsubsection{Avaliação no campo aberto durante o ciclo da cultura}

Para avaliação do desenvolvimento vegetativo no experimento a campo aberto, foram realizadas quatro amostragens de plantas. As amostragens foram realizadas por ocasião das floradas, quando mais de $50 \%$ das plantas das parcelas estavam com flor. Analisaram-se os seguintes parâmetros: matéria seca da parte aérea (MSPA), índice de área foliar (IAF), máxima dimensão horizontal da planta (DHP) e altura da planta (AP).

Para determinação da matéria seca da parte aérea e do índice de área foliar, em cada amostragem coletaram-se seis plantas das linhas centrais das sub-parcelas. As plantas foram cortadas rente ao solo e acondicionadas em sacos plásticos. No laboratório as plantas foram lavadas e separados os foliolos dos peciolos e dos frutos. Antes da secagem dos foliolos, a área foliar das plantas foi medida por "scanner". Em seguida, os folíolos, os pecíolos e os frutos foram secos em estufa, a $70^{\circ} \mathrm{C}$, até peso constante (Lucchesi \& Minami, 
1980). Finalmente, as amostras foram pesadas, e a MSPA foi obtida pelo somatório da matéria seca dos folíolos, dos pecíolos e dos frutos.

Para avaliação da altura e máxima dimensão horizontal da planta, foram amostradas três plantas por parcela, em cada florada.

\subsubsection{Avaliação no cultivo protegido durante o ciclo da cultura}

No cultivo protegido ocorreram apenas 3 floradas, avaliando-se em cada uma delas os seguintes parâmetros: altura e máxima dimensão horizontal da planta, número de folhas por planta, e medidas de largura e comprimento dos folíolos. A primeira florada no cultivo protegido ocorreu antes do antes do início dos tratamentos, por isso, nesta florada foram amostradas 25 plantas ao acaso e medidos os parâmetros acima citados. Nas segunda e terceira floradas, os mesmos parâmetros foram medidos em três plantas por parcela.

Para estimativa da área foliar das plantas, foram coletadas 25 folhas expandidas e saudáveis, em 8 de junho, totalizando 75 folíolos, localizados nos ápices dos pecíolos, de diferentes idades e tamanhos. Foram realizadas medidas de comprimento e largura dos folíolos e, posteriormente, determinada a área foliar por meio de "scanner". Para estimativa da área dos folíolos, considerou-se a similaridade do folíolo do morangueiro com a circunferência, como descrito a seguir:

$$
A f=\frac{\pi \cdot[(C+L) / 2]^{2}}{4}
$$

sendo Af a área do folíolo em $\mathrm{cm}^{2}, \mathrm{~L}$ a largura do folíolo em $\mathrm{cm}$, e C o comprimento do folíolo em $\mathrm{cm}$. Para realizar o ajuste de equações aos dados experimentais, foi utilizado um programa computacional que realiza o teste de 17 modelos de equações, desenvolvido por Zullo Jr. \& Arruda (1987). Também 
foram analisados os resultados, utilizando-se apenas uma dimensão, o comprimento ou a largura, porém o coeficiente de determinação $\left(R^{2}\right)$ foi sempre maior, quando se utilizou a média entre o comprimento e a largura. Os modelos que melhor se ajustaram aos dados experimentais foram: linear, hiperbólico, alométrico linear, curvilinear, e exponencial cúbico. Devido ao elevado valor de $\mathrm{R}^{2}(0,98)$ e à simplicidade de uso, utilizou-se o modelo linear. Dessa forma, a área dos folíolos foi estimada, conforme a relação apresentada a seguir:

$$
A F=-0,2432+(0,9783 . A f)
$$

sendo AF a área estimada por meio das medidas de largura e comprimento dos folíolos, segundo a equação (1).

Para a estimativa da área foliar da planta, foi contabilizado o número total de suas folhas, e medidos o comprimento e a largura de 15 de seus folíolos. Essas determinações realizaram-se na segunda e na terceira florada. Avaliou-se o comprimento e a largura de quinze folíolos por planta, em três plantas por parcela.

\subsubsection{Desenvolvimento vegetativo no final do ciclo}

No dia 22 de dezembro, após a última colheita, foi realizada amostragem de plantas, para avaliação do desenvolvimento vegetativo no final do ciclo, nos dois experimentos. Para essa amostragem foram coletadas 3 plantas por parcela. As plantas foram retiradas com auxílio de pá, a fim de não danificar o sistema radicular. $O$ excesso de solo aderido às plantas, principalmente nas raízes, foi retirado cuidadosamente, e em seguida as plantas foram acondicionadas em sacos plásticos. No laboratório, as plantas foram lavadas, e procedeu-se à separação da parte área e da parte subterrânea, na altura do colo da planta. 
$\mathrm{Na}$ parte aérea da planta, foram separados os folíolos dos pecíolos e dos frutos. A MSPA foi determinada conforme descrito no item 3.13.1. A área foliar foi medida utilizando-se medidor de área foliar (LICOR LI3100).

Para determinação da matéria seca da parte subterrânea (MSPS), após lavagem, o material foi colocado para secagem em estufa a $70^{\circ} \mathrm{C}$, até peso constante, seguido da pesagem final.

\subsection{Avaliação do sistema radicular}

$\mathrm{Na}$ avaliação do sistema radicular, as amostras foram retiradas aos 159 dias após o plantio (início da $3^{\mathrm{a}}$ florada), no cultivo a campo aberto. As amostragens foram realizadas nas parcelas com plástico preto e transparente, nos niveis de irrigação de - 0,010 e -0,070 MPa.

Para amostragem do sistema radicular, utilizou-se um trado tipo caneca, com $7 \mathrm{~cm}$ de diâmetro, conforme descrito por Fujiwara et al. (1994). As amostragens foram realizadas ao lado da planta, de $10 \mathrm{em} 10 \mathrm{~cm}$, até a profundidade de $60 \mathrm{~cm}$, com 5 repetições para cada combinação de cobertura do solo e nível de água.

As amostras foram acondicionadas em sacos plásticos, às quais adicionou-se uma solução alcoólica a $5 \%$. A separação das raízes foi feita pelo método de Gottingen (Bohm, 1979), por meio de lavagens sucessivas do material, com auxilio de uma peneira de malha $0,1 \mathrm{~mm}$ de abertura. As impurezas do solo, a matéria orgânica e as raízes mortas foram retiradas manualmente, com auxílio de uma pinça. Posteriormente, as raízes foram colocadas para secagem em estufa a $70^{\circ} \mathrm{C}$, até peso constante. $\mathrm{O}$ comprimento das raízes foi estimado pelo método da interseção de linhas (Tennant, 1975). A partir do comprimento das raízes, e conhecendo-se o volume da caneca, 
calculou-se a relação comprimento de raízes por $\mathrm{cm}^{3}$ de solo. Finalmente, foi calculada a distribuição porcentual das raízes, para determinação da profundidade efetiva do sistema radicular do morangueiro.

\subsection{Avaliação do impedimento físico à penetração no solo}

Para avaliação do impedimento físico à penetração no solo, parâmetro importante no desenvolvimento das raizes, foram realizados testes com penetrômetro de impacto modelo IAA/Planalsucar (Stolf et al., 1983). As determinações foram realizadas no início da $3^{a}$ florada, no mesmo dia da amostragem da profundidade de raízes, em 10 repetições em cada combinação de cobertura e nível de água do solo.

\subsection{Resistência estomática ao fluxo de difusão de vapor de água}

Para avaliação da resistência estomática, foi utilizado o porômetro de equilíbrio dinâmico (Licor LI-1600). As medições foram realizadas no periodo de 29 de agosto a 01 de setembro, no dia em que as irrigações eram necessárias e no dia seguinte. No campo aberto, a avaliação foi realizada nos três niveis de água no solo, no plástico preto, e, no transparente, apenas no nivel de -0,070 MPa. Já no cultivo protegido, as medições foram feitas nos niveis de -0,010 e -0,070 MPa, nas parcelas com plástico preto, e -0,070 MPa, naquelas com plástico transparente. Para essas avaliações, foram selecionadas folhas representativas, recém expandidas, maturas do topo do dossel vegetativo, expostas a pleno sol, e, sempre que possivel, com disposição horizontal. Em cada tratamento foram realizadas dez medições ao acaso. Inicialmente, as medidas foram realizadas nas duas superfícies da 
lâmina foliar; quando se detectou que as folhas eram hipostomáticas (com estômatos somente na superfície inferior da lâmina foliar). Portanto, as medições foram realizadas na lâmina inferior das folhas, sempre próximo ao meio dia local.

\subsection{Avaliação da produção}

Após a colheita, os frutos foram classificados em comerciáveis e não comerciáveis. Considerou-se frutos não comerciáveis aqueles com podridões, imperfeições físicas e ataque de insetos e pássaros. Após a classificação, os frutos foram contados e pesados.

Foi considerada como produção precoce aquela alcançada até julho (Camargo et al., 1974). A produção precoce tem elevada importância na comercialização, pois alcança cotações mais elevadas no mercado (Agrianual, 1997).

A produção comerciável (gramas), o número de frutos e o peso médio dos frutos, foram avaliados por planta, parcela nos seguintes períodos: até o final de julho (precoce), agosto, setembro, outubro, novembro, dezembro, e de junho a dezembro (total). 


\section{RESULTADOS E DISCUSSÃO}

\subsection{Temperatura do solo}

Nas Figuras 3 a 6 são apresentados os valores diários de temperatura máxima do solo, a $5 \mathrm{~cm}$ de profundidade, ocorridos nas diferentes coberturas do solo e níveis de água, no cultivo protegido e a campo aberto.

Comparando-se os intervalos de confiança das médias das temperaturas máximas, a $5 \%$ de probabilidade, observa-se que, no cultivo protegido, a temperatura sob plástico transparente foi significativamente menor que a ocorrida no plástico preto, nos níveis de água de -0,035 e -0,070 MPa (Figura 3B e $3 \mathrm{C}$ ). O mesmo não ocorreu para os resultados apresentados na Figura $3 \mathrm{~A}$, referentes ao nível de água de $-0,010 \mathrm{MPa}$, nos quais não foram observadas diferenças estatísticas. Por outro lado, no cultivo a campo aberto, a média das temperaturas máximas do solo sob plástico transparente foi maior que no plástico preto, em todos os níveis de água (Figura 5). Nesse caso, foram observadas diferenças significativas entre a temperatura máxima do solo, ocorrida sob as duas coberturas, independente do nível de irrigação e da ocorrência ou não de chuvas. 

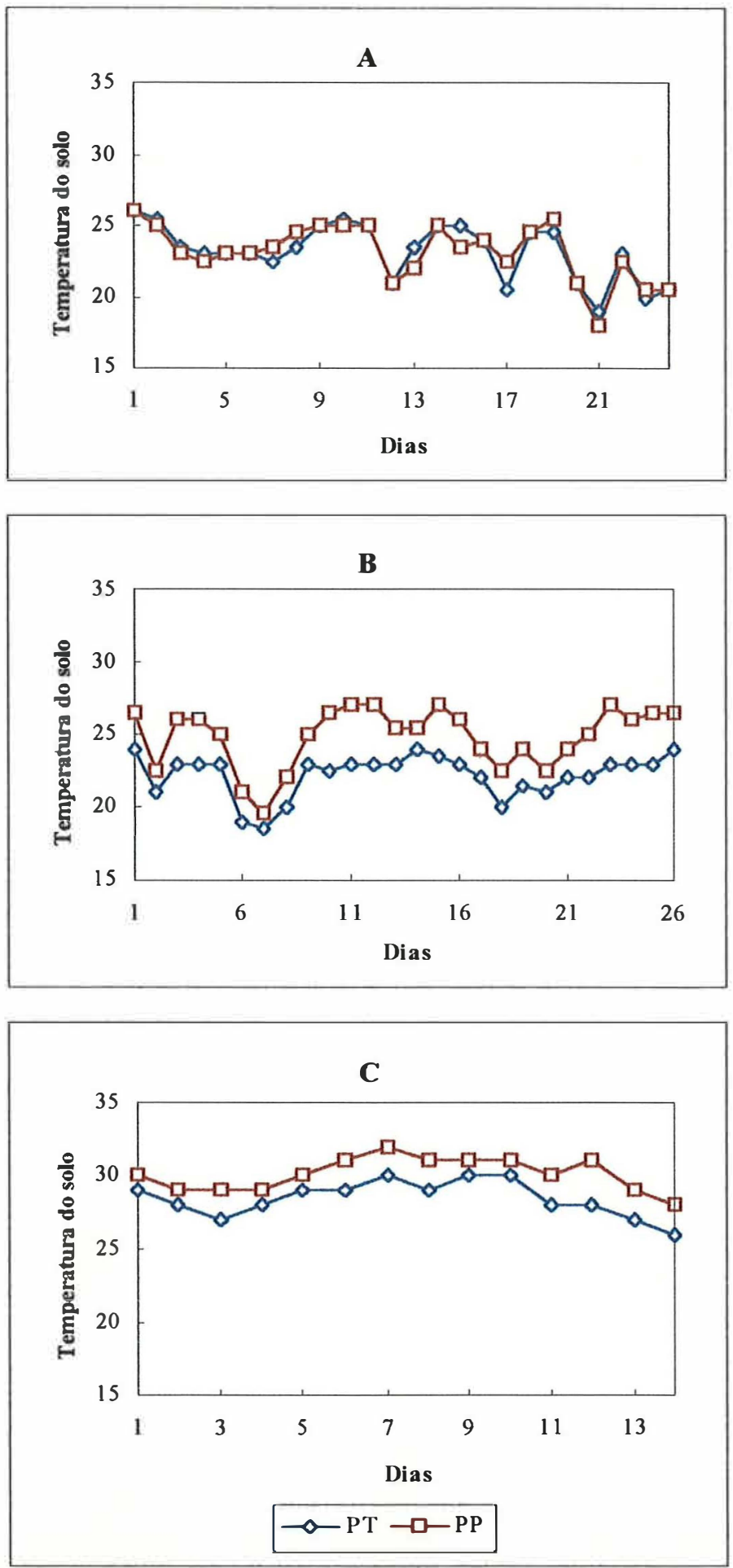

Figura 3 - Temperatura máxima diária do solo $\left({ }^{\circ} \mathrm{C}\right)$ a $5 \mathrm{~cm}$ de profundidade, sob plástico transparente $(\mathrm{PT})$ e plástico preto $(\mathrm{PP})$. As Figuras $\mathrm{A}, \mathrm{B}$ e $\mathrm{C}$ se referem aos níveis de água: - 0,010 $\mathrm{MPa}$ (1 a 24 de setembro), -0,035 MPa (3 a 28 de julho) e -0,070 MPa (21 de agosto a 3 de setembro) respectivamente, no morangueiro em cultivo protegido. 

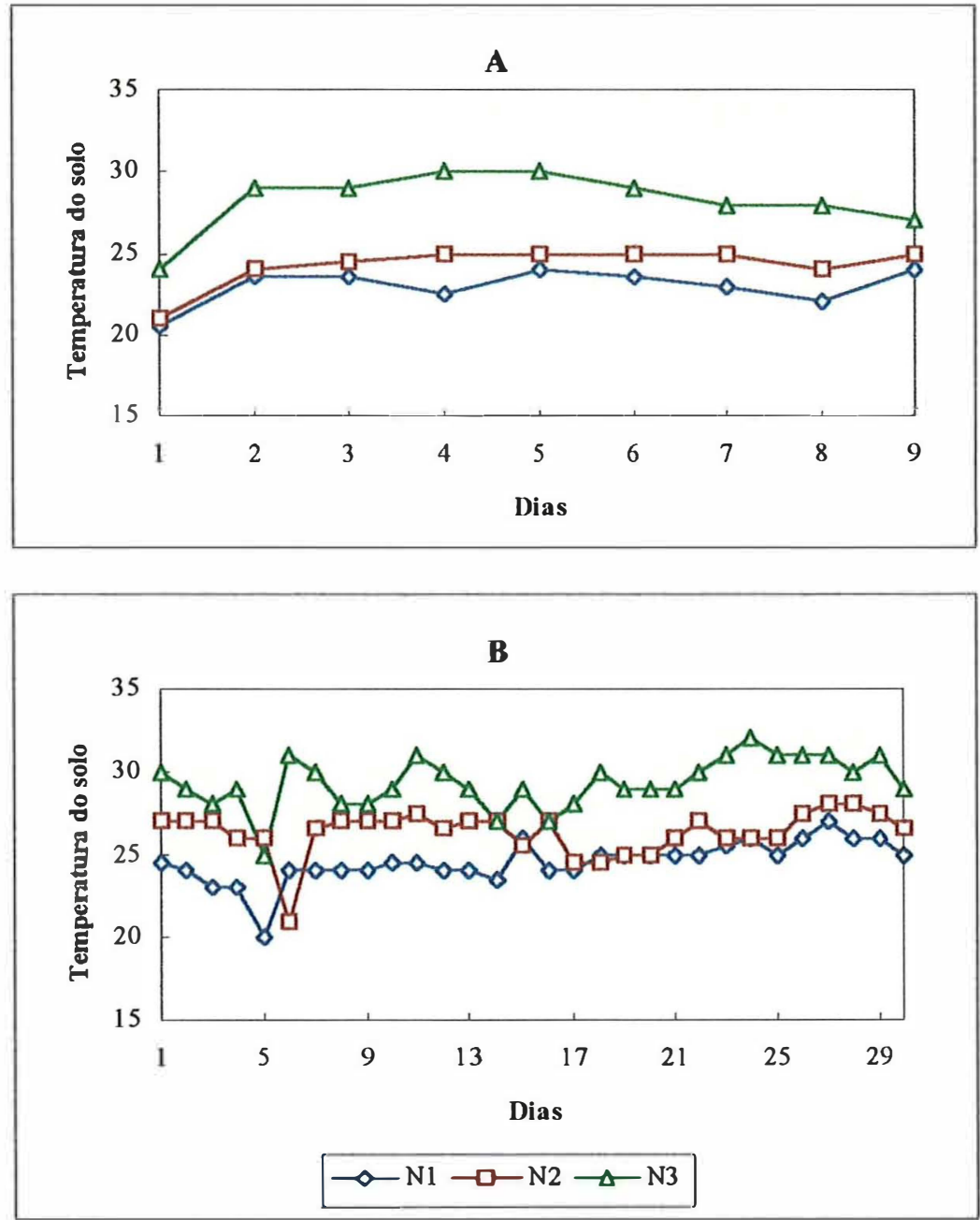

Figura 4 - Valores diários de temperatura máxima do solo $\left({ }^{\circ} \mathrm{C}\right)$ a $5 \mathrm{~cm}$ de profundidade, sob plástico transparente (A) no período de 1 a 9 de junho e sob plástico preto (B) no período de 1 a 30 de agosto, nos três níveis de água $-0,010$ (N1), $-0,035$ (N2) e -0,070 MPa (N3), no morangueiro em cultivo protegido, em Atibaia, SP. 

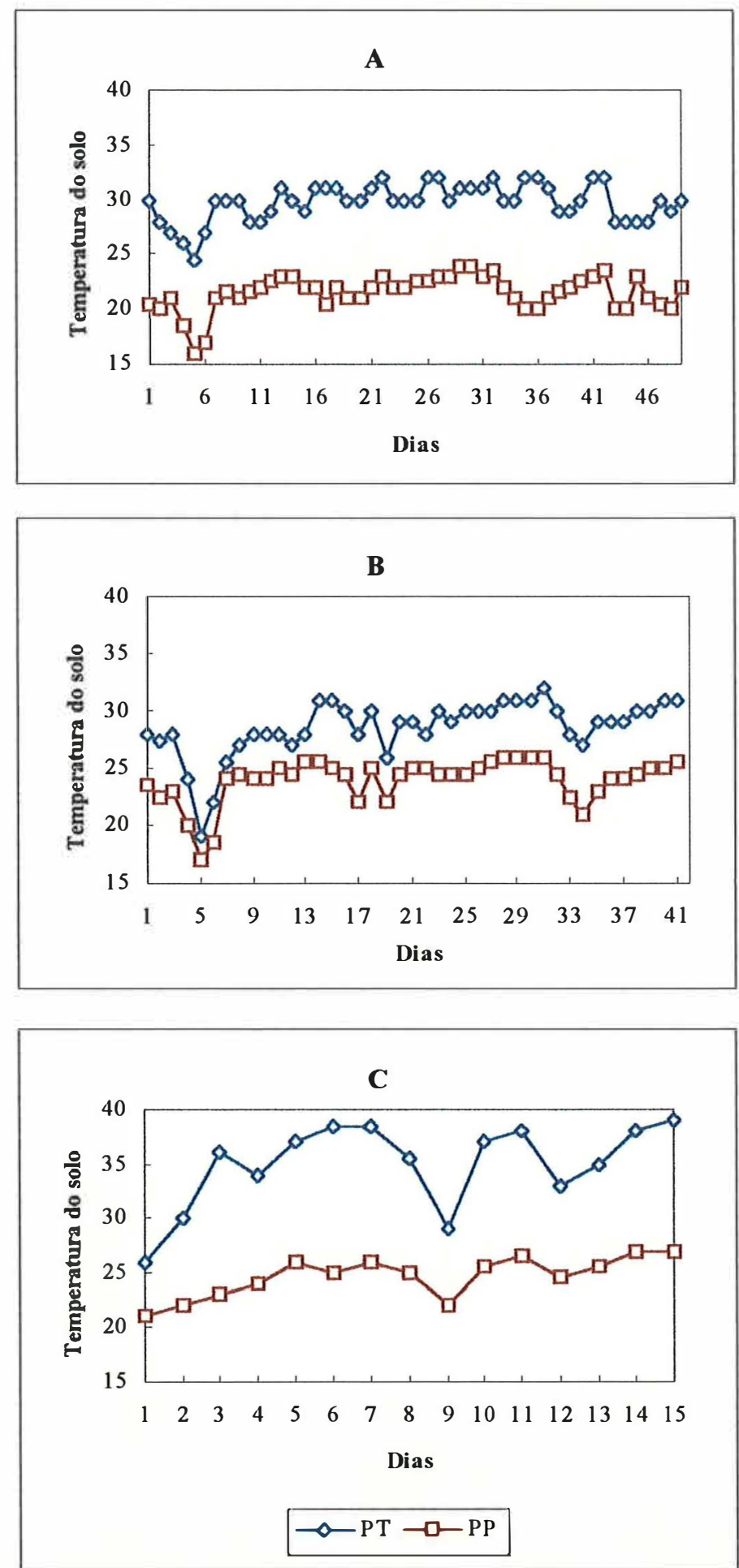

Figura 5 - Temperatura máxima diária do solo $\left({ }^{\circ} \mathrm{C}\right)$ a $5 \mathrm{~cm}$ de profundidade, sob plástico transparente (PT) e plástico preto (PP). As Figuras $A, B$ e $C$ se referem aos níveis de água: $-0,010 \mathrm{MPa}$ (1 de agosto a 18 de setembro), $-0,035 \mathrm{MPa}$ (1 de agosto a 10 de setembro) e -0,070 MPa (28 de setembro a 12 de outubro) respectivamente, no morangueiro em campo aberto. 

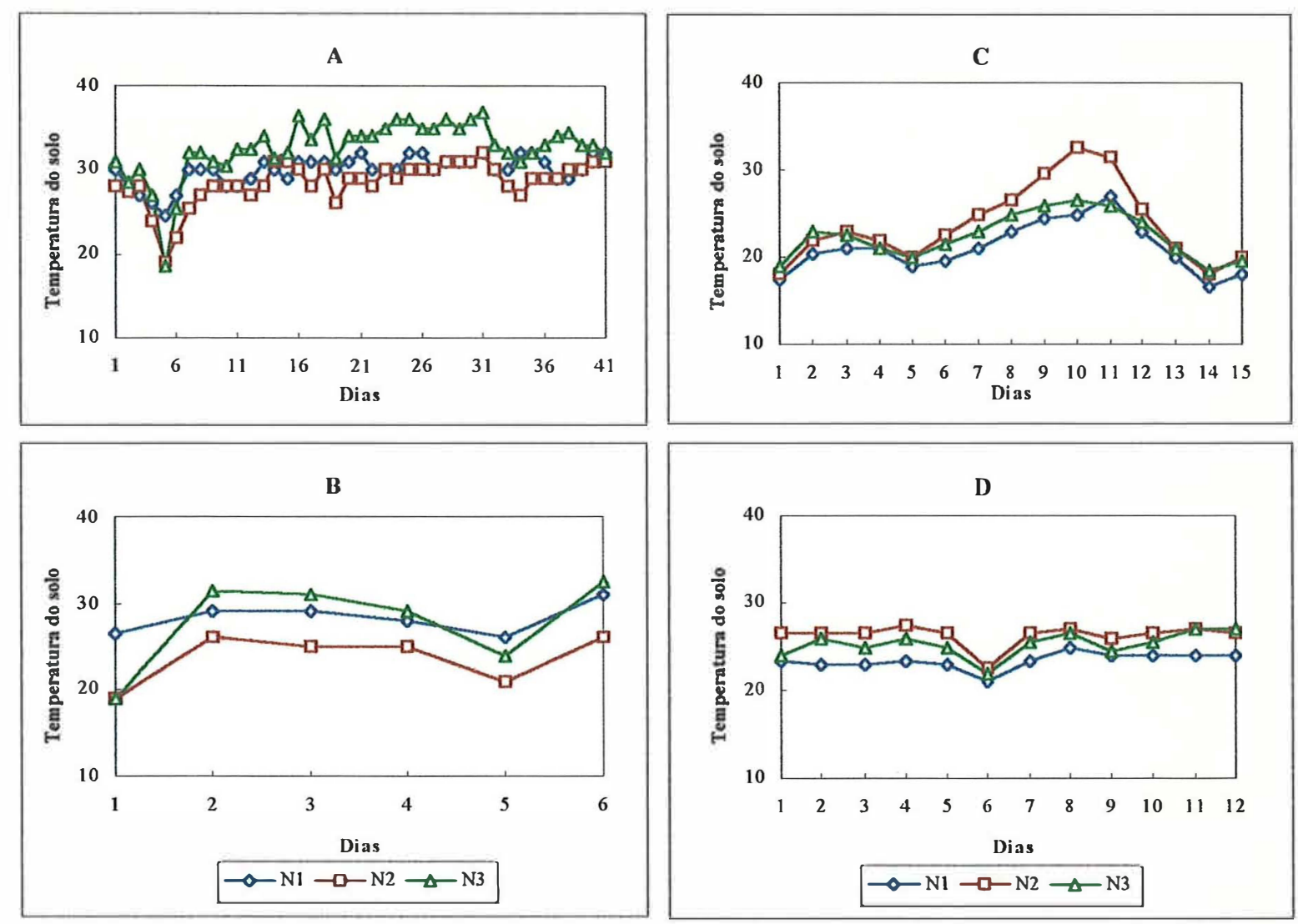

Figura 6 - Valores diários de temperatura máxima do solo $\left({ }^{\circ} \mathrm{C}\right)$ a $5 \mathrm{~cm}$ de profundidade, sob plástico transparente nos períodos de 1 de agosto a 10 de setembro (A) (período com pouca chuva) e de 17 a 22 de outubro (B) (período chuvoso); e sob plástico preto nos períodos de 17 a 31 de outubro (C) (período chuvoso) e de 1 a 12 de outubro (D) (período sem chuva), nos três níveis de água $-0,010$ (N1), $-0,035$ (N2) e -0,070 MPa (N3), no morangueiro cultivado a campo aberto, em Atibaia, SP, em 1995.

Com relação à influência dos níveis de água na temperatura do solo, no cultivo protegido, observou-se tendência de diminuição de temperatura nos tratamentos mais úmidos (Figura 4). Utilizando-se o plástico transparente, (Figura 4A) foram observadas diferenças significativas entre a temperatura do solo, no nível de água de -0,070 MPa e os demais (-0,035 e -0,010 MPa). Em média, a temperatura máxima no nível de água de $-0,070$ foi $3,9^{\circ} \mathrm{C}$ e $5,3^{\circ} \mathrm{C}$, maior em relação aos valores observados nos níveis de irrigação de -0,035 e 
$-0,010 \mathrm{MPa}$, respectivamente. Porém, entre os dois últimos, a diferença não foi significativa. Por outro lado, sob plástico preto (Figura 4B), ocorreram diferenças significativas entre os 3 níveis de água estudados. No nivel mais seco $(-0,070 \mathrm{MPa})$ observaram-se temperaturas médias acima dos demais da ordem de $3,0^{\circ} \mathrm{C}(-0,035 \mathrm{MPa})$ e $4,8^{\circ} \mathrm{C}(-0,010 \mathrm{MPa})$. Entre os níveis de água de $-0,010$ e $-0,035 \mathrm{MPa}$ a diferença média foi de $1,8^{\circ} \mathrm{C}$ a favor do nível intermediário $(-0,035 \mathrm{MPa})$.

No cultivo a campo aberto, os valores de temperatura do solo, nos diferentes níveis, foram apresentados em períodos chuvosos e secos, ou com pouca chuva (Figura 6). Não ocorreram diferenças significativas nos valores de temperatura do solo, medidos entre os níveis de água nos periodos chuvosos, para as duas coberturas do solo (Figura 6B e 6C). Sob plástico transparente, em períodos de pouca chuva (Figura 6A), a temperatura máxima do solo diferiu significativamente nos três níveis de água estudados. As maiores temperaturas máximas foram observadas no nível de $-0,070 \mathrm{MPa}$, com diferenças médias no período de $2,6^{\circ} \mathrm{C}$ e $4,1^{\circ} \mathrm{C}$, em relação aos níveis de água de $-0,010$ e $-0,035$ $\mathrm{MPa}$, respectivamente. No cultivo com plástico preto, foi observado, em período sem ocorrência de precipitações (Figura 6D), que a temperatura do solo foi menor no nível de $-0,010 \mathrm{MPa}$, diferindo significativamente dos demais níveis. Em média essas diferenças foram de $2,8^{\circ} \mathrm{C}$ e $1,8^{\circ} \mathrm{C}$ em relação aos níveis $-0,035$ e -0,070MPa, respectivamente. Entre os níveis de -0,035 e -0,070 MPa, não houve diferença significativa.

A Figura 7 apresenta os valores de temperatura máxima do solo, desde $1^{\circ}$ de agosto até 23 de setembro, no nível de irrigação de $-0,010 \mathrm{MPa}$, sob os plásticos transparente e preto, nos dois ambientes de cultivo. Nota-se que as temperaturas máximas sob plástico transparente foram maiores no cultivo a campo aberto, quando comparadas ao cultivo protegido, com diferença máxima de $9^{\circ} \mathrm{C}$, e média no período, de $5,9^{\circ} \mathrm{C}$. Sob plástico preto, observou-se que, no cultivo protegido, a temperatura máxima do solo atingiu 
valores maiores que os observados a campo aberto, sendo a maior diferença de $4,0^{\circ} \mathrm{C}$, e em média, de $2,2^{\circ} \mathrm{C}$, no período observado.

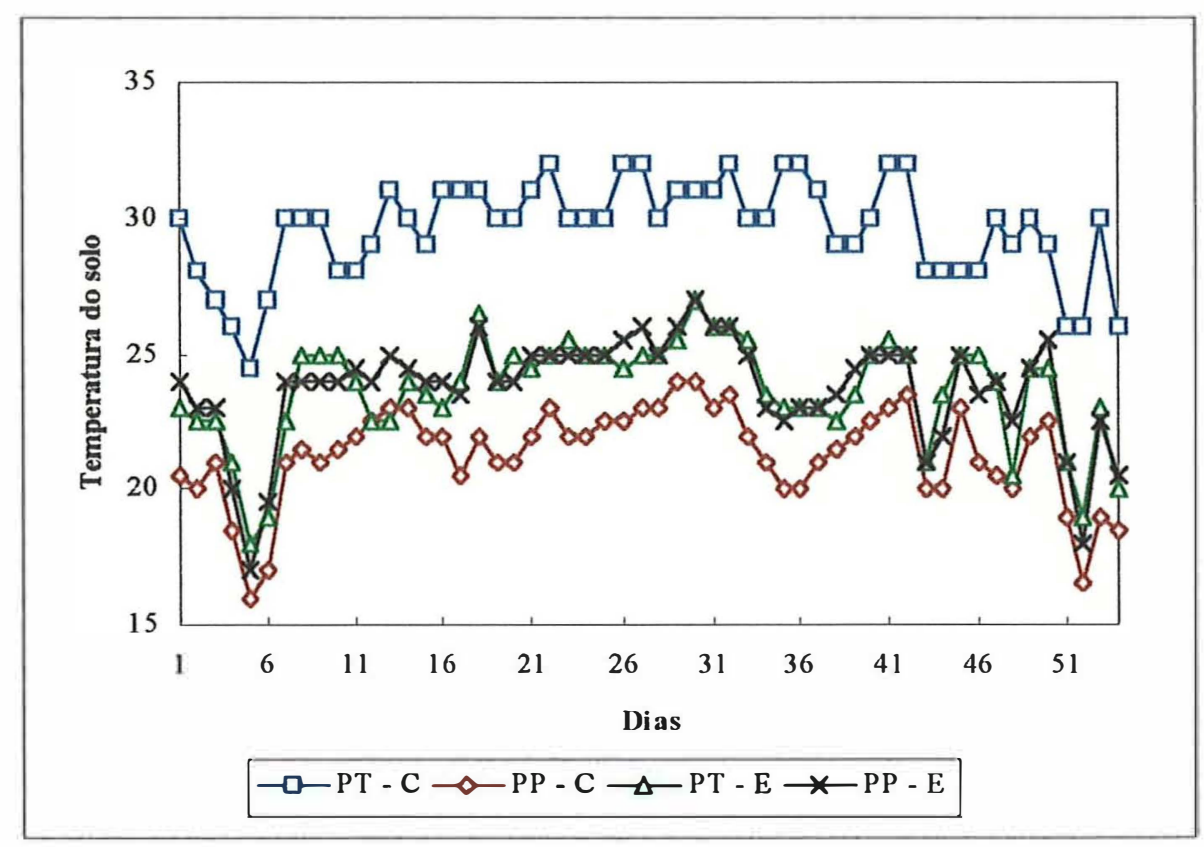

Figura 7 - Valores diários de temperatura máxima do solo $\left({ }^{\circ} \mathrm{C}\right)$ a $5 \mathrm{~cm}$ de profundidade, sob plástico transparente (PT) e plástico preto (PP) no cultivo a campo aberto (C) e em cultivo protegido (E), no morangueiro, no nível de irrigação de $-0,010 \mathrm{MPa}$, no período de 1 de agosto a 23 de setembro de 1995, em Atibaia, SP.

Passos (1997) não observou diferenças estatísticas entre a temperatura do solo sob plástico preto, ocorrida em cultivo protegido, e em condições de campo aberto.

Vários trabalhos comparando a temperatura do solo sob diferentes coberturas, encontraram maiores temperaturas sob o plástico transparente (Voth \& Bringhurst, 1990; Gupta \& Acharya, 1993 e Himelrick et al., 1993), concordando, também, com os observados no presente trabalho, no cultivo a campo aberto (Figura 5). Por outro lado, Martins (1983) e Ham et al. (1993) observaram temperaturas do solo maiores sob o plástico preto, quando 
comparadas ao transparente, de forma semelhante ao ocorrido no experimento no cultivo protegido (Figura 3). Liakatas et al. (1986) e Ham et al. (1993) ressaltam que, devido à interferência da camada de ar existente entre a cobertura e o solo, existem muitos trabalhos com resultados contraditórios relacionados à temperatura do solo. Pelo exposto, fica evidente a interação entre o tipo de cobertura do solo e sua forma de instalação na temperatura do solo.

Os valores de temperatura do solo ocorridos nos diferentes níveis de água e coberturas do solo podem auxiliar a interpretação dos resultados de desenvolvimento vegetativo, sanidade e produção, uma vez que exercem influência direta sobre os mesmos (Maas, 1984; Galletta \& Bringhurst, 1990).

\subsection{Irrigação}

A lâmina de água e o número de irrigações realizadas, no cultivo protegido e no campo aberto, encontram-se nas Tabelas 5 e 6 . No cultivo a campo aberto (Tabela 6), a lâmina total de água recebida pela cultura equivale ao somatório da lâmina líquida de irrigação com as precipitações ocorridas durante o ciclo (Tabela 4).

Tabela 5 - Valores totais de lâmina líquida $(\mathrm{mm})$ e número de irrigações realizadas durante 0 ciclo do morangueiro, nas diferentes coberturas de solo e niveis de irrigação ( $\mathrm{MPa}$ ) no cultivo protegido, em Atibaia, SP, em 1995.

\begin{tabular}{|c|c|c|c|c|c|c|}
\hline \multirow{2}{*}{$\begin{array}{c}\text { Níveis } \\
\text { de } \\
\text { água }\end{array}$} & \multicolumn{2}{|c|}{ Plástico transparente } & \multicolumn{2}{|c|}{ Plástico preto } & \multicolumn{2}{|c|}{ Média } \\
\hline & $\begin{array}{l}\text { Lâmina } \\
\text { líquida }\end{array}$ & $\begin{array}{c}N^{\circ} \text { de } \\
\text { irrigações }\end{array}$ & $\begin{array}{l}\text { Lâmina } \\
\text { líquida }\end{array}$ & $\begin{array}{c}N^{\circ} \text { de } \\
\text { irrigações }\end{array}$ & $\begin{array}{l}\text { Lâmina } \\
\text { líguida }\end{array}$ & $\begin{array}{c}N^{\circ} \text { de } \\
\text { irrigações }\end{array}$ \\
\hline $\mathrm{MPa}$ & $\cdots-m m$ & & $\overline{----m m----~}$ & & -.--mm- & \\
\hline$-0,010$ & 580,1 & 188,0 & 580,1 & 188,0 & 580,1 & 188,0 \\
\hline$-0,035$ & 490,1 & 99,0 & 502,1 & 101,0 & 496,1 & 100,0 \\
\hline$-0,070$ & 487,1 & 79,0 & 460,1 & 76,0 & 473,6 & 77,5 \\
\hline
\end{tabular}


Tabela 6 - Valores totais de número e lâmina líquida de irrigação (mm) realizadas, e lâmina total de água recebida durante o ciclo do morangueiro (irrigação mais precipitação), nas diferentes coberturas de solo, e niveis de irrigação ( $\mathrm{MPa})$ no cultivo a campo aberto, em Atibaia, SP, em 1995.

\begin{tabular}{|c|c|c|c|c|c|c|c|c|c|}
\hline \multirow{2}{*}{$\begin{array}{l}\text { Níveis } \\
\text { de } \\
\text { água }\end{array}$} & \multicolumn{3}{|c|}{ Plástico transparente } & \multicolumn{3}{|c|}{ Plástico preto } & \multicolumn{3}{|c|}{ Média } \\
\hline & $\begin{array}{l}\text { Lâmina } \\
\text { líquida }\end{array}$ & Lâmina & $N^{\circ} d$ & Lâmina & $\begin{array}{c}\text { Lâmina } \\
\text { total }\end{array}$ & $\begin{array}{l}\mathrm{N}^{\circ} \mathrm{de} \\
\text { irrig. }\end{array}$ & líqu & $\begin{array}{c}\text { Lâmina } \\
\text { total }\end{array}$ & $\begin{array}{l}\mathrm{N}^{\circ} \mathrm{de} \\
\text { irrig. }\end{array}$ \\
\hline $\mathrm{MPa}$ & $-\ldots-\cdots$ & & & $-n$ & $m_{-}$ & & -1 & m------- & \\
\hline 0,010 & 438 & & 140 & & & 140 & & & $0, U$ \\
\hline & 3 & & 75 & & & 76 & & & 75,5 \\
\hline 070 & 345,1 & 108,6 & 58 & 327,1 & 1090,6 & 56 & 336,1 & 1099,6 & 57,0 \\
\hline
\end{tabular}

De acordo com os resultados apresentados nas Tabelas 5 e 6 , observa-se que a influência das coberturas do solo nas lâminas de água e no número de irrigações foi pequena, em média da ordem de $2 \%$. De forma semelhante às lâminas e ao número de irrigações, os intervalos entre irrigações também foram pouco influenciados pelas coberturas do solo. Desta forma, os resultados relativos à irrigação serão apresentados e discutidos para os diferentes níveis de água, considerando-se a média dos valores observados nas duas coberturas do solo.

A diferenciação dos niveis de irrigação ocorreu a partir do dia 13 de junho no cultivo protegido, e 12 de junho no cultivo a campo aberto. As lâminas líquidas de irrigação, no cultivo protegido e no campo aberto, antes do início dos tratamentos, totalizaram respectivamente $136,1 \mathrm{~mm}$ e $114,1 \mathrm{~mm}$.

A partir dos resultados apresentados na Tabela 5, nota-se que, a lâmina líquida média diária aplicada durante o ciclo da cultura no cultivo protegido foi de 2,$3 ; 2,0$ e 1,9 mm/dia, para os níveis de água de $-0,010 ;-0,035$ e -0,070 MPa, respectivamente. Considerando-se na estimativa somente 0 período relativo aos tratamentos de niveis de irrigação, esses valores médios passam para 2,3; 1,9 e 1,7 mm/dia, respectivamente. Desta forma, observou-se que, à medida que o potencial de água no solo decresceu de $-0,010$ para 
-0,070 MPa, a lâmina líquida de irrigação diminuiu. Esse resultado concorda com o observado por Serrano et al. (1992) na região da Catalunha, na Espanha, onde a lâmina de irrigação média diária variou de 2,3 a 1,3 mm/dia, utilizando potenciais de água no solo de $-0,010$ a $-0,070 \mathrm{MPa}$, respectivamente. Para as condições de Bologna, na Itália, Rossi Pisa et al. (1989) mediram o consumo de água do morangueiro, cv. Fern, de 2 a $3 \mathrm{~mm} /$ dia, valores próximos ao obtido no tratamento mais úmido (-0,010 MPa), no cultivo protegido.

A partir dos valores acumulados da evaporação do tanque classe A (ECA) e das lâminas líquidas de irrigação, aplicadas no cultivo protegido e a campo aberto, no período de $1^{\circ}$ de julho a 22 de dezembro, foi estimado o fator de consumo de água (f) da cultura, de forma similar a Olitta (1980) e McNiesh et al. (1985):

$$
f=\frac{\text { lâmina líquida de irrigação }}{\text { ECA }}
$$

sendo $\mathrm{f}$ o fator de consumo de água, a lâmina líquida de irrigação em mm, e a ECA a evaporação do tanque classe $A$ em $\mathrm{mm}$. O fator $f$ relaciona a ECA ao manejo de água adotado nos experimentos. Em média, no cultivo protegido, os valores de $\mathbf{f}$ observados foram $0,55,0,44$ e 0,42, respectivamente, para os níveis de água de $-0,010,-0,035$ e -0,070 MPa, e os valores de pico, na mesma seqüência foram, $0,63,0,52$ e 0,51. Os valores de pico ocorreram em agosto e setembro. No cultivo a campo aberto, os valores médios foram $0,41,0,34 \mathrm{e}$ 0,29, e os picos de 0,52, 0,54 e 0,47, no mês de agosto, para N1, N2 e N3, respectivamente. Os valores médios e de pico do fator de consumo de água, no nível de irrigação de $-0,010 \mathrm{MPa}$ no cultivo protegido, são próximos aos observados por McNiesh et al. (1985) na Califórnia, e menores que o recomendado por Olitta (1980), em condições de campo aberto em Piracicaba, SP. 
No cultivo protegido, os valores do fator $f$ retratam a influência dos diferentes níveis de irrigações adotados na necessidade de água pela cultura, uma vez que não ocorreu interferência das precipitações. Já no cultivo a campo aberto, os valores refletem o efeito conjunto do manejo de água, e da ocorrência de precipitações, durante a experimentação.

Com relação à lâmina total de água, Olitta (1980) relatou a aplicação de 790 e 1129 mm em 2 anos consecutivos de experimentação, com morangueiro $\mathrm{cv}$. SH2, para as condições de Piracicaba, SP. Essa lâmina de água considera as precipitações naturais ocorridas no período dos experimentos, e é próxima dos valores observados no experimento em condições de campo aberto (Tabela 6). Giovanardi \& Testolin (1984) avaliaram o consumo de água de $485 \mathrm{~mm}$, durante o ciclo do morangueiro, na Itália, utilizando o critério de irrigar sempre que consumido $20 \%$ da água disponível do solo. Serrano et al. (1992) aplicaram lâminas de água de 566 a $313 \mathrm{~mm}$ durante o ciclo do morangueiro de acordo com o potencial de água no solo adotado (de $-0,010$ a $-0,070 \mathrm{MPa}$ ). Verifica-se que esses valores foram semelhantes aos das lâminas de irrigação aplicadas no cultivo protegido (Tabela 5).

A lâmina total de água recebida pela cultura no campo aberto foi bem maior que a aplicada no cultivo protegido (Tabelas 5 e 6). No campo aberto, as plantas receberam mais que o dobro da água aplicada na estufa. No cultivo a campo aberto, as irrigações contribuiram, em média, com 36,5; 33,3 e $30,6 \%$, do total de lâmina de água recebida pela cultura (Tabela 6), nos níveis de água de -0,010; -0,035 e -0,070 MPa, respectivamente.

De acordo com os resultados observados nas Tabelas 5 e 6, notase que a influência dos diferentes níveis de água utilizados foi mais acentuada no número de irrigações do que nas lâminas de água. Em média, a lâmina de água aumentou em $22 \%$, quando o potencial de água no solo passou de $-0,070$ $\mathrm{MPa}$ para -0,010 $\mathrm{MPa}$, no cultivo protegido, e $9 \%$ no campo aberto, 
considerando a inclusão das precipitações. Levando-se em conta apenas as lâminas de irrigação no campo aberto, esse aumento foi de $30 \%$. Com relação ao número de irrigações, houve aumento médio de $143 \%$ no cultivo protegido, e de $146 \%$ no campo aberto, comparando-se os mesmos níveis de água.

Desde o plantio até o início dos tratamentos, foram realizadas 41 irrigações no cultivo protegido, e 32 no cultivo a campo aberto. Cerca de $75 \%$ e 83\% destas irrigações ocorreram com intervalo entre irrigações de 1 dia, no cultivo protegido e no campo aberto, respectivamente. Na fase inicial de pegamento da cultura, as irrigações frequentes são importantes para evitar estresse hídrico na planta, e para diminuir o efeito de elevadas temperaturas do ar. Por esses motivos, grande parte dos produtores aplicam quantidades excessivas de água, resultando em condições favoráveis à disseminação de alguns patógenos (Maas, 1984).

A partir da diferenciação dos níveis de água, os intervalos entre irrigações, nos dois ambientes de cultivo, foram contabilizados e analisados em relação à sua freqüência de ocorrência, de forma similar a Pires et al. (1988). Os resultados estão apresentados na Tabela 7.

Os intervalos entre irrigações variaram em função do nivel de irrigação adotado, assim como com o ambiente de cultivo (Tabela 7). Os intervalos tiveram maior amplitude de variação no cultivo a campo aberto quando comparados aos observados no cultivo protegido, devido principalmente a influência das precipitações naturais (Tabela 4).

Analisando-se a maior parte das irrigações (cerca de 75 a $80 \%$ ), observa-se que estas foram realizadas a intervalo entre irrigações de $1 \mathrm{dia}$, de 1 a 4 dias, e de 2 a 6 dias, no cultivo protegido, nos níveis N1, N2, e N3, respectivamente (Tabela 7). Já no cultivo a campo aberto, o mesmo percentual de irrigações ocorreu a intervalos que variaram de 1 a 2 dias, de 1 a 5 dias, e de 2 a 11 dias, para os níveis N1, N2 e N3 (Tabela 7). Nos dois ambientes de cultivo, no nível de $-0,010 \mathrm{MPa}$, a maior parte das irrigações ocorreram a 
intervalos próximos aos observados por Olitta \& Minami (1974), Dwyer et al. (1987), Passos (1997) e Pomares et al. (1994), isto é de 1 a 3 dias.

Tabela 7 - Freqüência de ocorrência (\%) dos intervalos entre irrigações, ocorridos nos níveis de irrigação de $-0,010$ (N1), $-0,035$ (N2) e $-0,070$ (N3) $\mathrm{MPa}$, no cultivo protegido (de 13 de junho a 22 dezembro), e a campo aberto (de 12 de junho a 22 de dezembro), no morangueiro, em 1995, em Atibaia, SP.

\begin{tabular}{|c|c|c|c|c|c|c|}
\hline \multirow{3}{*}{$\begin{array}{c}\text { Intervalo } \\
\text { entre } \\
\text { irrigações }\end{array}$} & \multicolumn{6}{|c|}{ Níveis de água (MPa) } \\
\hline & \multicolumn{3}{|c|}{ Cultivo protegido } & \multicolumn{3}{|c|}{ Campo aberto } \\
\hline & $-0,010$ & $-0,035$ & $-0,070$ & $-0,010$ & $-0,035$ & $-0,070$ \\
\hline -- dias --- & 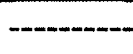 & 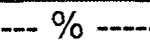 & 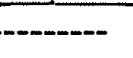 & - & $\%$ & - \\
\hline 1 & 74,1 & 2,6 & & 67,6 & 4,6 & \\
\hline 2 & 22,2 & 29,9 & 6,8 & 21,3 & 29,9 & 4,0 \\
\hline 3 & 1,7 & 35,0 & 21,9 & 1,9 & 19,5 & 18,0 \\
\hline 4 & 2,0 & 14,5 & 17,8 & 0,9 & 13,8 & 24,0 \\
\hline 5 & & 9,4 & 13,7 & 2,8 & 11,5 & 8,0 \\
\hline 6 & & 7,7 & 15,1 & 1,9 & 3,4 & 6,0 \\
\hline 7 & & 0,9 & 8,2 & 1,9 & 1,1 & 2,0 \\
\hline 8 & & & 5,5 & 0 & 2,3 & 4,0 \\
\hline 9 & & & 5,5 & 0 & 6,9 & 0 \\
\hline 10 & & & 2,7 & 0,9 & 2,3 & 4,0 \\
\hline 11 & & & 2,7 & 0 & 0 & 6,0 \\
\hline 12 & & & & 0,9 & 0 & 0 \\
\hline 13 & & & & & 1,1 & 12,0 \\
\hline 14 & & & & & 0 & 0 \\
\hline 15 & & & & & 0 & 2,0 \\
\hline 16 & & & & & 3,4 & 0 \\
\hline 17 & & & & & & 4,0 \\
\hline 18 & & & & & & 0 \\
\hline 19 & & & & & & 0 \\
\hline 20 & & & & & & 0 \\
\hline 21 & & & & & & 4,0 \\
\hline 22 & & & & & & 2,0 \\
\hline $\begin{array}{c}\mathrm{N}^{\circ} \mathrm{de} \\
\text { irrigações }\end{array}$ & 294 & 118 & 73 & 216 & 87 & 50 \\
\hline
\end{tabular}

De acordo com os resultados apresentados nas Tabelas 5, 6 e 7, observa-se a influência do ambiente de cultivo e do manejo das irrigações no número e lâminas de irrigação, e nos intervalos entre irrigações. No cultivo protegido os intervalos entre irrigações foram menores, e, as lâminas líquidas e 
o número de irrigações maiores, que os do campo aberto. Essa diferença foi influenciada pela ocorrência das chuvas no campo aberto (Tabela 4), e, possivelmente, pelo desenvolvimento das plantas nos dois ambientes de cultivo. Os níveis de água no solo utilizados influenciaram a lâmina, o número e o intervalo entre irrigações. Quanto mais úmido o tratamento, maior a lâmina líquida e o número de irrigações e menor o intervalo entre regas.

\subsection{Teor de nutrientes nas folhas}

Os resultados da avaliação de nutrientes nas folhas, na segunda florada, no cultivo protegido e a campo aberto, encontram-se nas Tabelas 8 a 11.

Considerando os teores médios de macronutrientes no limbo foliar, por ocasião da segunda florada, verificou-se que a interação entre coberturas do solo e níveis de irrigação não foi significativa no cultivo protegido, nem no campo aberto.

No cultivo protegido não houve efeito das coberturas do solo e dos níveis de irrigação, para os teores de $\mathrm{N}, \mathrm{P}, \mathrm{K}$ e Mg. O teor de Ca no limbo foliar foi significativamente maior no cultivo com plástico transparente, e nos níveis de irrigação -0,010 e -0,035 MPa (Tabela 8).

De acordo com os resultados apresentados na Tabela 9, no cultivo a campo aberto, nota-se que não houve efeito dos níveis de irrigação sobre os teores de N, P, K, Ca e Mg, no limbo foliar das plantas. Com relação às coberturas do solo, não ocorreram diferenças significativas nos teores de $P$, $\mathrm{K}$ e Mg (Tabela 9). $\mathrm{O}$ teor de $\mathrm{N}$ foi favorecido pelo uso do plástico preto, já o teor de Ca pelo uso do plástico transparente. O plástico transparente favoreceu o teor de cálcio nos dois ambientes. 
Tabela 8 - Teores médios de macronutrientes no limbo foliar (\%), na $2^{a}$ florada do morangueiro no cultivo protegido, nas diferentes coberturas do solo e níveis de irrigação (MPa), em Atibaia, SP, em 1995. $a^{*} b^{\star *}$

\begin{tabular}{lccccc}
\hline \multicolumn{1}{c}{ Itens } & $\mathrm{N}$ & $\mathrm{P}$ & $\mathrm{K}$ & $\mathrm{Ca}$ & $\mathrm{Mg}$ \\
\hline Coberturas do solo & & & & & \\
Plástico transparente & $3,168 \mathrm{a}$ & $0,293 \mathrm{a}$ & $1,954 \mathrm{a}$ & $1,447 \mathrm{a}$ & $0,417 \mathrm{a}$ \\
Plástico preto & $3,131 \mathrm{a}$ & $0,278 \mathrm{a}$ & $1,845 \mathrm{a}$ & $1,371 \mathrm{~b}$ & $0,419 \mathrm{a}$ \\
\hline Níveis de imigação & & & & & \\
$-0,010$ & $3,193 \mathrm{a}$ & $0,299 \mathrm{a}$ & $1,928 \mathrm{a}$ & $1,451 \mathrm{a}$ & $0,432 \mathrm{a}$ \\
$-0,035$ & $3,122 \mathrm{a}$ & $0,282 \mathrm{a}$ & $1,892 \mathrm{a}$ & $1,453 \mathrm{a}$ & $0,413 \mathrm{a}$ \\
$-0,070$ & $3,134 \mathrm{a}$ & $0,275 \mathrm{a}$ & $1,878 \mathrm{a}$ & $1,324 \mathrm{~b}$ & $0,408 \mathrm{a}$ \\
\hline $\mathrm{CV}(\%)$ & 3,5 & 7,8 & 8,0 & 6,2 & 8,4 \\
\hline
\end{tabular}

$\mathrm{a}^{*} \mathrm{o} \mathrm{teor} \mathrm{em} \mathrm{\%} \mathrm{equivale} \mathrm{a} \mathrm{g} / \mathrm{kg}$ dividido por 10 .

$\mathrm{b}^{*}$ dentro de cada ítem as médias de cada nutriente seguidas da mesma letra não diferem entre si pelo teste de Tukey $(\mathrm{P}<0,05)$.

Tabela 9 - Teores médios de macronutrientes no limbo foliar (\%), na $2^{\mathrm{a}}$ florada do morangueiro cultivado a campo aberto, nos diferentes tratamentos de cobertura do solo e níveis de irrigação (MPa), em Atibaia, SP, em1995. $a^{\star} b^{\star}$

\begin{tabular}{lccccc}
\hline \multicolumn{1}{c}{ Itens } & $\mathrm{N}$ & $\mathrm{P}$ & $\mathrm{K}$ & $\mathrm{Ca}$ & $\mathrm{Mg}$ \\
\hline Coberturas do solo & & & & & \\
Plástico transparente & $2,919 \mathrm{~b}$ & $0,294 \mathrm{a}$ & $2,065 \mathrm{a}$ & $1,437 \mathrm{a}$ & $0,353 \mathrm{a}$ \\
Plástico preto & $3,033 \mathrm{a}$ & $0,310 \mathrm{a}$ & $2,038 \mathrm{a}$ & $1,333 \mathrm{~b}$ & $0,337 \mathrm{a}$ \\
\hline Niveis de irrigação & & & & & \\
$-0,010$ & $2,999 \mathrm{a}$ & $0,314 \mathrm{a}$ & $2,131 \mathrm{a}$ & $1,378 \mathrm{a}$ & $0,336 \mathrm{a}$ \\
$-0,035$ & $2,938 \mathrm{a}$ & $0,298 \mathrm{a}$ & $2,061 \mathrm{a}$ & $1,399 \mathrm{a}$ & $0,349 \mathrm{a}$ \\
$-0,070$ & $2,991 \mathrm{a}$ & $0,294 \mathrm{a}$ & $1,962 \mathrm{a}$ & $1,379 \mathrm{a}$ & $0,350 \mathrm{a}$ \\
\hline $\mathrm{CV}(\%)$ & 2,9 & 7,3 & 9,0 & 5,5 & 9,1 \\
\hline
\end{tabular}

$\mathrm{a}^{\star}$ o teor em \% equivale a $\mathrm{g} / \mathrm{kg}$ dividido por 10 .

$b^{*}$ dentro de cada ítem as médias de cada nutriente seguidas da mesma letra não diferem entre si pelo teste de Tukey $(P<0,05)$.

Com relação ao resultado dos micronutrientes, observou-se que a interação entre coberturas do solo e níveis de irrigação não foi significativa nos dois experimentos (cultivo protegido e campo aberto).

Os teores de micronutrientes no limbo foliar não apresentaram diferenças significativas com relação aos níveis de irrigação, tanto no cultivo protegido como no campo aberto (Tabelas 10 e 11). 
Tabela 10 - Teores médios de micronutrientes no limbo foliar (ppm ou mg/kg), na $2^{\mathrm{a}}$ florada do morangueiro no cultivo protegido, nas diferentes coberturas do solo e níveis de irrigação (MPa), em Atibaia, SP, em 1995. a*

\begin{tabular}{lccccc}
\hline \multicolumn{1}{c}{ Ítens } & $\mathrm{B}$ & $\mathrm{Cu}$ & $\mathrm{Fe}$ & $\mathrm{Mn}$ & $\mathrm{Zn}$ \\
\hline Coberturas do solo & & & & & \\
Plástico transparente & $42,5 \mathrm{a}$ & $7,9 \mathrm{~b}$ & $267,7 \mathrm{a}$ & $143,0 \mathrm{a}$ & $28,7 \mathrm{a}$ \\
Plástico preto & $39,8 \mathrm{a}$ & $9,0 \mathrm{a}$ & $270,3 \mathrm{a}$ & $110,1 \mathrm{~b}$ & $27,9 \mathrm{a}$ \\
\hline Níveis de imigação & & & & & \\
$-0,010$ & $39,1 \mathrm{a}$ & $8,6 \mathrm{a}$ & $260,7 \mathrm{a}$ & $129,4 \mathrm{a}$ & $30,2 \mathrm{a}$ \\
$-0,035$ & $42,8 \mathrm{a}$ & $8,4 \mathrm{a}$ & $275,4 \mathrm{a}$ & $138,3 \mathrm{a}$ & $28,7 \mathrm{a}$ \\
$-0,070$ & $41,5 \mathrm{a}$ & $8,2 \mathrm{a}$ & $270,9 \mathrm{a}$ & $111,9 \mathrm{a}$ & $26,1 \mathrm{a}$ \\
\hline $\mathrm{CV}(\%)$ & 9,8 & 13,0 & 9,4 & 27,8 & 15,2 \\
\hline
\end{tabular}

$\mathrm{a}^{\star}$ dentro de cada ítem as médias de cada nutriente seguidas pela mesma letra, não diferem entre si pelo teste de Tukey $(P<0,05)$.

Tabela 11 - Teores médios de micronutrientes no limbo foliar (ppm ou mg/kg), na $2^{\mathrm{a}}$ florada do morangueiro cultivado a campo aberto, nas diferentes coberturas do solo e níveis de irrigação (MPa), em Atibaia, SP, em 1995. $a^{*}$

\begin{tabular}{lccccc}
\hline \multicolumn{1}{c}{ Itens } & $\mathrm{B}$ & $\mathrm{Cu}$ & $\mathrm{Fe}$ & $\mathrm{Mn}$ & $\mathrm{Zn}$ \\
\hline Coberturas do solo & & & & & \\
Plástico transparente & $41,5 \mathrm{a}$ & $14,0 \mathrm{a}$ & $347,9 \mathrm{a}$ & $262,9 \mathrm{a}$ & $89,1 \mathrm{a}$ \\
Plástico preto & $41,1 \mathrm{a}$ & $12,9 \mathrm{a}$ & $293,6 \mathrm{~b}$ & $247,9 \mathrm{a}$ & $89,3 \mathrm{a}$ \\
\hline Níveis de imigação & & & & & \\
$-0,010$ & $40,9 \mathrm{a}$ & $12,7 \mathrm{a}$ & $315,3 \mathrm{a}$ & $269,4 \mathrm{a}$ & $94,9 \mathrm{a}$ \\
$-0,035$ & $40,7 \mathrm{a}$ & $14,0 \mathrm{a}$ & $321,1 \mathrm{a}$ & $234,0 \mathrm{a}$ & $94,1 \mathrm{a}$ \\
$-\mathrm{O}, 070$ & $42,4 \mathrm{a}$ & $13,7 \mathrm{a}$ & $325,9 \mathrm{a}$ & $262,2 \mathrm{a}$ & $78,5 \mathrm{a}$ \\
\hline $\mathrm{CV}(\%)$ & 6,2 & 19,1 & 13,0 & 26,9 & 37,8 \\
\hline
\end{tabular}

$\mathrm{a}^{*}$ dentro de cada ítem as médias de cada nutriente seguidas pela mesma letra, não diferem entre si pelo teste de Tukey $(P<0,05)$.

Com relação às coberturas do solo, no cultivo protegido, não ocorreram diferenças significativas nos teores de B, Fe e Zn (Tabela 10). O teor de $\mathrm{Cu}$ foi favorecido pelo cultivo com plástico preto, e o de $\mathrm{Mn}$ pelo plástico transparente.

No cultivo a campo aberto não houve efeito das coberturas do solo sobre os teores de $\mathrm{B}, \mathrm{Cu}, \mathrm{Mn}$ e $\mathrm{Zn}$, no limbo foliar. O teor de $\mathrm{Fe}$ foi 
significativamente superior no cultivo com plástico transparente, quando comparado ao preto (Tabela 11).

Os resultados obtidos no presente estudo, apresentados nas Tabelas de 8 a 11, serão interpretados segundo Ulrich et al. (1980), Souza et al. (1981a e 1981b) e Schiavinato ${ }^{6}$, citado por Castellane (1993), apesar das diferenças metodológicas quanto os cultivares e à seleção das folhas para análise.

Segundo Ulrich et al. (1980), no cultivo protegido todos os nutrientes analisados nas Tabelas 8 e 10 se encontravam na faixa adequada para a cultura, ou seja não apresentavam sintomas de deficiência nutricional. Por outro lado, segundo Souza et al. (1981a e 1981b) os teores de $\mathrm{P}$ e $\mathrm{Fe}$ estavam baixos, e o $\mathrm{Mn}$, elevado, estando os demais nutrientes com valores adequados. Segundo Schiavinato ${ }^{6}$, os valores de $\mathrm{K}$ e Mg estavam baixos, $\mathrm{N}$ alto e $\mathrm{P}$ e $\mathrm{Ca}$ adequados.

No cultivo a campo aberto, segundo Ulrich et al. (1980) somente o teor de Zn estava um pouco elevado, situando-se os demais na faixa adequada (Tabelas 9 e 11). Já de acordo com Souza et al. (1981a e 1981b) o $P$ se encontrava um pouco baixo e $\mathrm{Zn}$ e Mn elevados. Segundo Schiavinato ${ }^{6}$ os teores de $\mathrm{K}$ e $\mathrm{Mg}$ estavam baixos, $\mathrm{N}$ alto e $\mathrm{P}$ e $\mathrm{Ca}$ adequados.

A diversificação nas interpretações dos resultados de macro e micronutrientes segundo Ulrich et al. (1980), Souza et al. (1981a e 1981b) e Schiavinato ${ }^{6}$ devem estar associadas a diferenças metodológicas adotadas, como cultivar, amostragem de folhas (considerando todas as folhas ou somente as jovens ou ainda levando em conta o limbo foliar isoladamente ou com o pecíolo) e período de amostragem durante o ciclo da cultura conforme discutido por Passos (1997).

\footnotetext{
${ }^{6}$ SCHIAVINATO. R.J. Diagnose visual de algumas deficiências minerais e suas codificações na cultura do morangueiro Fragaria sp. Jaboticabal. 1990.6lp. Monografia (Graduação) - Faculdade de Ciências Agrárias e Veterinárias, Universidade Estadual Paulista "Júlio de Mesquita Filho".
} 
A coleta de material para análise nutricional das plantas adotada no presente trabalho foi a mesma de Ulrich et al. (1980), considerando-se apenas o limbo foliar, portanto, os resultados das Tabelas 8 a 11 se enquadram melhor segundo essas interpretações. Além disso, deve-se ressaltar que, mundialmente a interpretação do teor de nutrientes nas folhas conforme esses autores é utilizada. Desta forma, observa-se que, apesar de ocorridas diferenças significativas no teor de alguns nutrientes em função dos níveis de água e coberturas do solo, estes se encontravam na faixa adequada para a cultura, exceto o elevado teor de $\mathrm{Zn}$ no cultivo a campo aberto (Ulrich et al., 1980). Portanto, de um modo geral, os tratamentos adotados, não devem ter influenciado o desenvolvimento das plantas, uma vez que não havia deficiência nutricional.

\subsection{Sistema radicular}

Os resultados da avaliação do sistema radicular do morangueiro em cultivo a campo aberto, sob as diferentes coberturas do solo, nos níveis de irrigação de -0,010 e -0,070 MPa, são apresentados na Tabela 12.

Tabela 12 - Valores médios do comprimento de raiz por volume de solo $\left(\mathrm{cm} / \mathrm{cm}^{3}\right)$ do morangueiro cultivado em plástico transparente (PT) e preto (PP), nos níveis de água de $-0,010$ e $-0,070 \mathrm{MPa}$, em diferentes profundidades, aos 159 dias após o plantio, no cultivo a campo aberto, em Atibaia, SP, em 1995. $a^{*}$

\begin{tabular}{ccc|cc}
\hline \multirow{2}{*}{$\begin{array}{c}\text { Profundidade } \\
(\mathrm{cm})\end{array}$} & \multicolumn{2}{c|}{ Coberturas do solo } & \multicolumn{2}{c}{ Níveis de irrigação (MPa) } \\
\cline { 2 - 5 } & PT & PP & $-0,010$ & $-0,070$ \\
\hline $0-10$ & $2,254 \mathrm{a}$ & $2,367 \mathrm{a}$ & $2,471 \mathrm{a}$ & $2,150 \mathrm{a}$ \\
$10-20$ & $1,715 \mathrm{a}$ & $1,805 \mathrm{a}$ & $1,730 \mathrm{a}$ & $1,790 \mathrm{a}$ \\
$20-30$ & $1,434 \mathrm{a}$ & $1,101 \mathrm{a}$ & $1,042 \mathrm{a}$ & $1,492 \mathrm{a}$ \\
$30-40$ & $0,979 \mathrm{a}$ & $0,742 \mathrm{a}$ & $0,877 \mathrm{a}$ & $0,843 \mathrm{a}$ \\
$40-50$ & $0,448 \mathrm{a}$ & $0,531 \mathrm{a}$ & $0,433 \mathrm{a}$ & $0,547 \mathrm{a}$ \\
$50-60$ & $0,260 \mathrm{a}$ & $0,448 \mathrm{a}$ & $0,244 \mathrm{a}$ & $0,464 \mathrm{a}$ \\
\hline
\end{tabular}

$a^{\star}$ em cada camada de profundidade para as coberturas de solo, e para os níveis de imigação, as médias seguidas pela mesma letra não diferem entre si pelo teste de Tukey $(P<0,05)$. 
A interação entre níveis de água e coberturas do solo não foi significativa nas diferentes profundidades estudadas. De acordo com os resultados da Tabela 12, observa-se que as coberturas do solo e niveis de irrigação não influenciaram o desenvolvimento radicular do morangueiro em condições de campo.

Os resultados da Tabela 12 indicam maior concentração de raízes nas camadas superficiais. Devido às características de desenvolvimento do sistema radicular do morangueiro, isso já era esperado (Galletta \& Bringhurst, 1990). As raízes são renovadas continuamente durante o ciclo da cultura. As radicelas mais novas vão se formando a partir do rizoma, em posição acima das mais velhas, caracterizando um sistema radicular pouco profundo (Natividade ${ }^{4}$ ).

Galletta \& Bringhurst (1990) observaram que a temperatura do solo de $12,7^{\circ} \mathrm{C}$ promoveu desenvolvimento ótimo no sistema radicular do morangueiro, nos cultivares Lassen e Shasta. De acordo com os resultados apresentados nas Figuras 5 e 6 , verifica-se que os valores foram sempre superiores a $12,8^{\circ} \mathrm{C}$, nos períodos avaliados. Apesar da temperatura do solo sob plástico transparente ter sido significativamente maior que sob plástico preto (Figura $5 \mathrm{~A}$ e $5 \mathrm{C}$ ), com diferenças médias de 8,3 e $10,3^{\circ} \mathrm{C}$, nos níveis de água de -0,010 e -0,070 MPa, respectivamente, no período analisado, estas diferenças não foram suficientes para refletir variações no comprimento de raiz (Tabela 12). Com relação aos níveis de água, as diferenças ocorridas na temperatura do solo foram menores, com diferença significativa apenas nos períodos secos ou com pouca chuva (Figura 6A e 6D).

A Tabela 13 apresenta a distribuição porcentual do sistema radicular, em comprimento de raiz por volume de solo.

Os resultados de distribuição do sistema radicular do morangueiro, obtidos no presente estudo (Tabelas 12 e 13), diferem dos apresentados por Inforzatto \& Camargo (1973), que encontraram mais de $70 \%$ das raízes até $5 \mathrm{~cm}$ de profundidade, utilizando o cv. Campinas. Tais diferenças podem ter ocorrido em 
função das diferenças metodológicas adotadas. No presente trabalho, foram consideradas apenas as raízes finas, e os resultados apresentados em comprimento de raiz por $\mathrm{cm}^{3}$ de solo, diferindo de Inforzatto \& Camargo (1973), que utilizaram o peso seco. Outro fator que pode ter interferido nos resultados obtidos por Inforzatto \& Camargo (1973) é o teor de alumínio no solo, que estava elevado, podendo ter contribuído para que o sistema radicular do morangueiro não tivesse se aprofundado.

Tabela 13 - Distribuição porcentual média e acumulada (\%) do comprimento de raiz por volume de solo, do sistema radicular do morangueiro cultivado em plástico transparente (PT) e preto (PP), nos níveis de água de $-0,010$ e -0,070 MPa, em função da profundidade, aos 159 dias após 0 plantio, no cultivo a campo aberto, em Atibaia, SP, em 1995.

\begin{tabular}{|c|c|c|c|c|c|c|c|c|}
\hline \multirow{3}{*}{$\begin{array}{c}\text { Profundidade } \\
\text { (cm) }\end{array}$} & \multicolumn{4}{|c|}{ Coberturas do solo } & \multicolumn{4}{|c|}{ Níveis de imigação (MPa) } \\
\hline & \multicolumn{2}{|c|}{ PT } & \multicolumn{2}{|c|}{$\mathrm{PP}$} & \multicolumn{2}{|c|}{$-0,010$} & \multicolumn{2}{|c|}{$-0,070$} \\
\hline & $\%$ & $\%$ ac. & $\%$ & $\%$ ac. & $\%$ & $\%$ ac. & $\%$ & $\%$ ac. \\
\hline $0-10$ & 31,8 & 31,8 & 33,8 & 33,8 & 36,4 & 36,4 & 29,5 & 29,5 \\
\hline $10-20$ & 24,2 & 56,0 & 25,8 & 59,6 & 25,5 & 61,9 & 24,6 & 54,1 \\
\hline $20-30$ & 20,2 & 76,2 & 15,7 & 75,3 & 15,3 & 77,2 & 20,5 & 74,6 \\
\hline $30-40$ & 13,8 & 90,0 & 10,6 & 85,9 & 12,9 & 90,1 & 11,6 & 86,2 \\
\hline $40-50$ & 16,3 & 96,3 & 7,6 & 93,5 & 6,4 & 96,5 & 7,5 & 93,7 \\
\hline $50-60$ & 3,7 & 100,0 & 6,5 & 100,0 & 3,5 & 100,0 & 6,3 & 100,0 \\
\hline
\end{tabular}

Cerca de $75 \%$ das raízes concentraram-se até $30 \mathrm{~cm}$ de profundidade (Tabelas 12 e 13). Este resultado está de acordo com o obtido e utilizado para o manejo das irrigações no morangueiro, em vários locais e cultivares (McNiesh et al., 1985; Dwyer et al., 1987; Strabbioli, 1988; Rossi Pisa et al., 1989; Stanley \& Maynard, 1990 e Serrano et al., 1992).

Os resultados da avaliação da compactação do solo, com penetrômetro nas diferentes coberturas, encontram-se na Figura 8. 

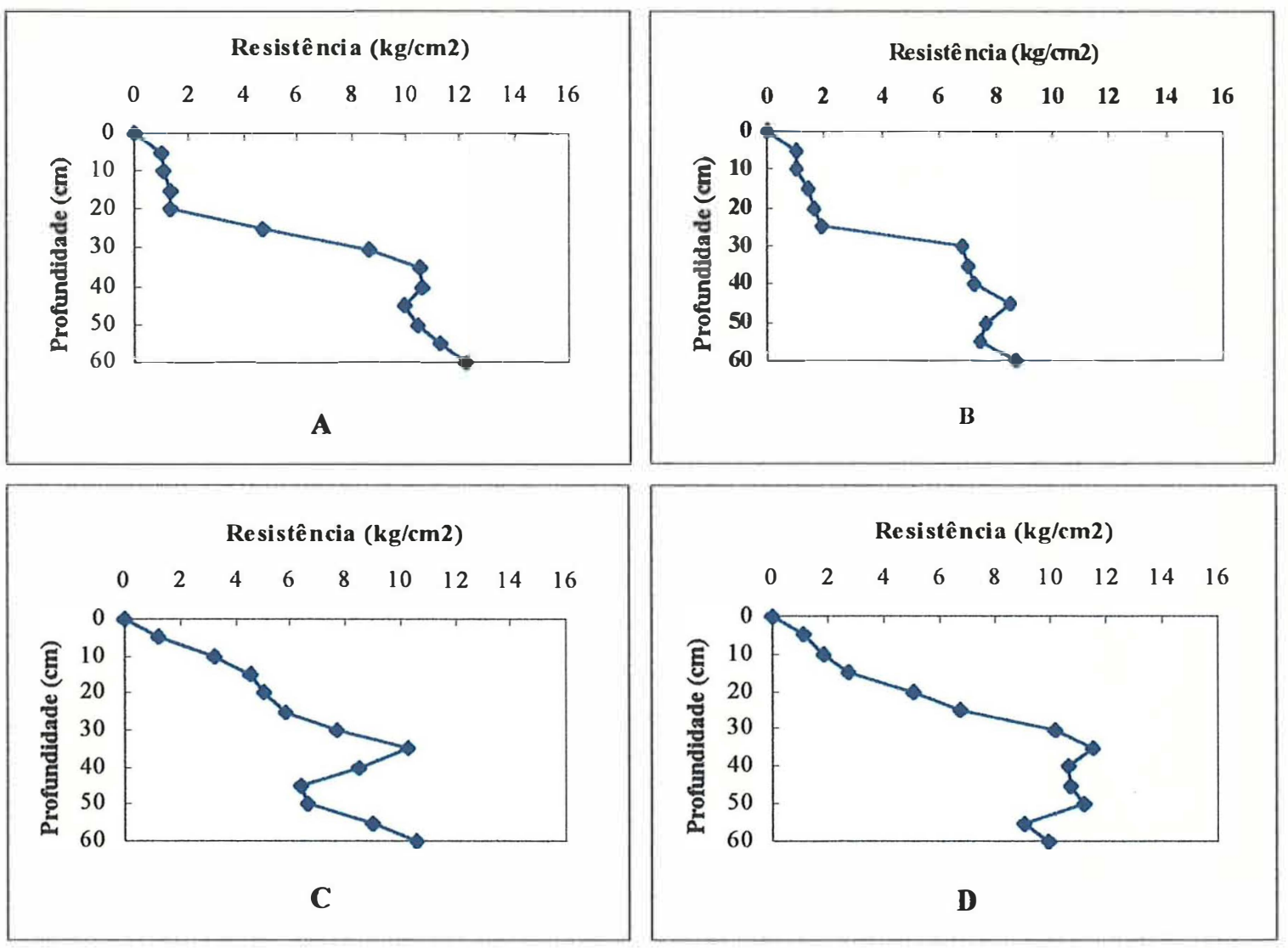

Figura 8 - Resistência média a penetração $\left(\mathrm{kg} / \mathrm{cm}^{2}\right)$, em função da profundidade do solo, no nível de água de $-0,010 \mathrm{MPa}$ no plástico transparente $(\mathrm{A})$ e preto (B) e no nível de $-0,070 \mathrm{MPa}$ no plástico transparente $(\mathrm{C})$ e preto (D) no cultivo do morangueiro, em Latossolo Vermelho Amarelo, textura argilosa, em Atibaia, SP, em 1995.

Os valores de resistência à penetração representam a combinação das características físicas e da umidade do solo. Observa-se que, nos níveis mais úmidos de irrigação (Figuras $8 \mathrm{~A}$ e $8 \mathrm{~B}$ ), os valores de resistência do solo à penetração, no início do perfil, foram bem menores que os ocorridos nos níveis de água de $-0,070 \mathrm{MPa}$ (Figura $8 \mathrm{C}$ e $8 \mathrm{D}$ ). Para os diferentes níveis de água e coberturas do solo, a camada mais compactada localizou-se a partir de 30 a $40 \mathrm{~cm}$ de profundidade (Figura 8). A localização da camada mais compactada nesta faixa de profundidade pode estar associada ao sistema de cultivo em canteiros (com 
altura de $30 \mathrm{~cm}$ ), e às técnicas de preparo do solo, podendo ter afetado o desenvolvimento das raízes, uma vez que os resultados das análises física e química do solo (Tabelas 1 e 2 ) não indicaram possivel restrição ao desenvolvimento radicular, embora estas análises tenham sido realizadas antes da confecção dos canteiros. Entretanto, há que se considerar que o sistema radicular do morangueiro é caracterizado por raízes pouco profundas (Natividade ${ }^{4}$ ).

De acordo com os resultados observados a profundidade efetiva do sistema radicular do morangueiro foi de $30 \mathrm{~cm}$ (Tabela 13), e não se observou efeito dos diferentes níveis de água e coberturas de solo no comprimento das raízes em cada faixa de profundidade estudada (Tabela 12).

\subsection{Avaliação da sanidade das plantas}

A ocorrência de problemas fitossanitários nas plantas foi diferente ao longo do ciclo do morangueiro, nos dois experimentos.

Em junho, começaram a surgir algumas plantas com sintoma de mancha angular (bacteriose - Xanthomonas fragariae), no campo aberto. A incidência tornou-se homogênea e com alta intensidade em julho. Ainda nesse mês, no campo aberto, também ocorreu mancha de micosferela de forma homogênea, porém com menor intensidade que a manha angular. As precipitações naturais (Tabela 4) e o orvalho podem ter favorecido a incidência tanto da mancha de micosferela como da bacteriose, no cultivo a campo aberto (Maas, 1984; Rodrigues Neto et al., 1994).

No cultivo protegido, em junho, houve ataque de ácaros, que foi facilmente controlado. Afora o ataque dessa praga, no cultivo protegido, as plantas permaneceram sem problemas fitossanitários até a primeira quinzena de setembro, época em que a produção de frutos começa a declinar. Desta forma, nota-se que o 
cultivo protegido constituiu-se em técnica valiosa para o manejo de pragas e doenças no morangueiro.

A partir da segunda quinzena de setembro, começaram a aparecer algumas plantas com sintoma de murcha e/ou sub-desenvolvimento, no cultivo protegido e no campo aberto. No campo aberto também houve morte de algumas plantas doentes. Esta incidência pode estar associada a inúmeros fatores, entre eles, a ocorrência de condições climáticas favoráveis ao desenvolvimento dos agentes causais, principalmente a elevação da temperatura máxima do ar no final de agosto, e elevação das mínimas a partir da segunda quinzena de setembro, com consequente elevação da temperatura média (Tabelas 3 e 4), conforme salientam Maas (1984); Smith \& Black (1987) e Okayama (1989), e presença de patógenos no solo, devido à eventual ineficiência na fumigação do mesmo. Além disso, também existe a possibilidade das mudas terem sido portadoras dos patógenos, cujos sintomas só se manifestaram com a presença de condições predisponentes (Mclnnes et al., 1992).

No cultivo protegido foram realizadas duas avaliações do número de plantas murchas e/ou subdesenvolvidas por parcela. Os resultados obtidos encontram-se na Tabela 14.

As interações entre níveis de água e épocas de amostragem; níveis de água e coberturas de solo; épocas de amostragem e coberturas de solo não foram significativas. De acordo com os resultados da Tabela 14, observa-se que houve efeito dos níveis de água e das coberturas de solo no número de plantas murchas elou subdesenvolvidas (doentes). O número de plantas doentes foi significativamente menor no plástico transparente, quando comparado ao plástico preto. Com relação aos níveis de irrigação, o número de plantas doentes foi significativamente inferior nos níveis de $-0,010$ e -0,035 MPa, quando comparado ao nível -0,070 $\mathrm{MPa}$. O número de plantas doentes na segunda época de amostragem (27/10/95) foi significativamente maior que o observado na primeira amostragem. 
Tabela 14 - Avaliação do número médio de plantas doentes com sintoma de murcha e/ou subdesenvolvimento, por parcela $\left(3,6 \mathrm{~m}^{2}\right)$, no cultivo protegido nas diferentes coberturas de solo e níveis de irrigação (MPa), em 2 épocas distintas (02/10/95 e 27/10/95), no morangueiro em Atibaia, SP, em 1995. $a^{*}$

\begin{tabular}{lcc}
\hline İtens & Número de plantas murchas e/ou subdesenvolvidas \\
\cline { 2 - 3 } & $02 / 10 / 95$ & $27 / 10 / 95$ \\
\hline Coberturas do solo & $2,2 \mathrm{~B}$ & $7,4 \mathrm{~B}$ \\
Plástico transparente & $7,1 \mathrm{~A}$ & $18,3 \mathrm{~A}$ \\
Plástico Preto & $2,7 \mathrm{~B}$ & \\
\hline Níveis de imigação & $2,3 \mathrm{~B}$ & $6,8 \mathrm{~B}$ \\
$-0,010$ & $8,9 \mathrm{~A}$ & $9,7 \mathrm{~B}$ \\
$-0,035$ & $4,6 \mathrm{~b}$ & $22,1 \mathrm{~A}$ \\
$-0,070$ & $\mathrm{CV}_{\text {sub-parceta }}=29,3 \%$ & $12,9 \mathrm{a}$ \\
\hline Média & & \\
\hline $\mathrm{CV}_{\text {parcela }}=55,3 \%$ & & \\
$\mathrm{a}^{*}$ dentro de cada ítem, as médias seguidas pela mesma letra (maiúscula na vertical e minúscula na \\
horizontal) não diferem entre si pelo teste de Tukey (P<0,05).
\end{tabular}

A maior incidência de plantas doentes no cultivo com plástico preto (Tabela 14) pode estar associada à maior temperatura do solo observada com esta cobertura, quando comparada ao plástico transparente (Figura 3). Camargo \& Igue (1973) e Passos (1997) atribuíram a maior incidência de antracnose (Colletotrichum fragariae) no plástico preto à maior temperatura do solo observada, quando comparada a outras coberturas avaliadas. Da mesma forma, a temperatura do solo no nível de água de -0,070 MPa foi significativamente maior, quando comparada aos demais níveis (Figura 4). Outro aspecto que pode ter favorecido a ocorrência de doenças no nível de água mais seco $(-0,070 \mathrm{MPa})$ é o maior intervalo entre irrigações ocorrido neste nível, quando comparado aos demais (Tabela 7). Passos (1997) também observou a maior incidência de doenças no morangueiro em condições de irrigações menos freqüentes.

O aumento do número de plantas doentes nas duas épocas amostradas (Tabela 14) deve ter ocorrido devido ao acúmulo de inóculo com o passar do tempo, responsável por esse acréscimo gradual. 
Para identificação dos patógenos presentes no cultivo protegido, foi realizada amostragem de plantas. Os fungos identificados, assim como sua porcentagem de ocorrência e nível de intensidade, encontram-se na Tabela 15.

Tabela 15 - Porcentagem de ocorrência e nível de intensidade de fungos identificados em amostras de morangueiro com sintomas de murcha e/ou subdesenvolvimento, retiradas no cultivo protegido em 18/10/95, em Atibaia, SP.

\begin{tabular}{lcc}
\hline \multicolumn{1}{c}{ Fungos identificados } & Ocorrência (\%) & Nível de Intensidade $\mathrm{a}^{*}$ \\
\hline Rhizoctonia spp. & 83,0 & ++ \\
Verticillium dahliae & 58,3 & ++ \\
Fusarium spp. & 58,3 & + \\
Colletotrichum fragariae & 50,0 & ++ \\
Pythium spp. & 8,3 & + \\
Phytophthora cactorum & 8,3 & + \\
\hline a $^{*}+++$ fungo isolado e observado de forma predominante na maioria das amostras examinadas; ++ \\
fungo isolado com freqüência média, não de forma predominante; + fungo isolado com baixa \\
freqüência.
\end{tabular}

No cultivo protegido, em $100 \%$ das plantas amostradas com sintoma de murcha elou subdesenvolvimento (Tabela 15), sempre estavam presentes, isolados ou conjuntamente, os fungos Rhizoctonia spp., Verticillium dahliae e Colletotrichum fraganiae. A presença de Colletotrichum e/ou Verticillium foi observada em $83 \%$ das plantas amostradas.

No cultivo a campo aberto, a incidência de doenças foi homogênea, por isso não se contabilizou o número de plantas doentes. Neste ambiente, foi realizada coleta de plantas para identificação dos patógenos presentes e associação aos sintomas observados na parte aérea da planta, de forma similar a Passos (1997). Os resultados estão apresentados na Tabela 16.

A ocorrência das doenças de forma homogênea, no campo aberto, a partir da segunda quinzena de setembro, pode ter sido decorrente da distribuição uniforme de propágulos no solo e favorecida pela dispersão de fungos por impacto das gotas de água das precipitações nas plantas (Maas, 1984; Yang et al., 1992), uma vez que nem as diferenças na temperatura do solo, observadas entre os 
plásticos transparente e preto, em todos os níveis de água (Figura 5), afetaram o desenvolvimento de doenças. Embora os resultados obtidos por Yang et al. (1992), tenham sido obtidos para doenças da parte aérea, patógenos como Rhizoctonia spp., C. fragariae e $P$. cactorum (Tabela 16) também produzem lesões em pecíolos, frutos e estolhos. O inóculo dessas lesões pode ser disseminado pelo impacto das gotas de água e atingir o rizoma e/ou o sistema radicular.

O morangueiro é uma planta sensível ao excesso e ao déficit hídrico (McNiesh et al., 1985), por isso irrigações excessivas ou uma exposição por período prolongado de saturação do solo e a consequente diminuição na concentração de oxigênio $\left(\mathrm{O}_{2}\right)$ no solo, tendem a aumentar a incidência ou a severidade de doenças causadas por Pythium spp., Rhizoctonia spp., Colletotrichum fraganiae e Phytophthora cactorum (Rotem \& Palti, 1969; Maas, 1984 e Wing et al., 1995). Todos esses fungos foram observados nos dois ambientes de cultivo (Tabelas 15 e 16). Wing et al. (1995) observaram também que condições de excesso de umidade no solo favorecem a podridão preta das raízes, cujo agente causal não é bem conhecido, e parece estar associado a vários fungos de solo. Esses autores ainda verificaram correlação positiva entre a compactação do solo e a ocorrência de podridão negra nas raízes. Para as profundidades de 10, 18 e $26 \mathrm{~cm}$, encontraram valores de resistência à penetração que variaram de 3 a $17 \mathrm{~kg} / \mathrm{cm}^{2}$ e, em média $11 \mathrm{~kg} / \mathrm{cm}^{2}$. De acordo com a Figura 8 , nota-se que, nas camadas mais compactadas, ocorreram valores próximos aos médios citados por Wing et al. (1995), portanto é possível que a compactação do solo também possa ter favorecido o desenvolvimento das doenças. No presente trabalho, no cultivo a campo aberto, apesar do manejo das irrigações por meio de tensiômetros, as plantas receberam também água das precipitações (Tabela 4), e, consequentemente, o excesso de água foi inevitável. Esse pode ter sido um dos motivos pelos quais a infestação de patógenos no cultivo a campo aberto foi homogênea em todo o experimento. 
Tabela 16- Fungos predominates associados a sintomas visuais de doenças com os respectivos níveis de intensidade, em morangueiro cultivado a campo aberto, em 27/11/95, em Atibaia, SP.

\begin{tabular}{l} 
Sintomas \\
\hline A-Plantas subdesenvolvidas, folhas jovens de tamanho \\
reduzido, folhas velhas secas. \\
-Sistema radicular pobre, algumas raizes pretas.Lesões \\
necróticas marrom-avermelhadas.
\end{tabular}

\begin{tabular}{l}
\hline$B_{1}$-Plantas de tamanho normal, com murcha, mais \\
acentuada nas horas mais quentes do dia, com broto \\
apodrecido e pecíolos avermelhados. \\
-Sistema radicular com desenvolvimento médio, pouco \\
ramificado, com muitas raízes pretas; raízes \\
apodrecidas nos pontos de inserção com os rizomas. \\
Vasos um pouco escurecidos. \\
\hline$B_{2}$ - Idem ao $\mathrm{B}$, sem murcha e sem escurecimento de \\
vasos.
\end{tabular}

C-Plantas subdesenvolvidas, com avermelhamento de
peciolos, principalmente das folhas velhas.

-Sistema radicular pobre, com muitas raízes pretas.

Necroses marrom avermelhadas nas laterais do rizoma.

Rhizoctonia spp. (broto,
raizes e rizomas)
Colletotrichum fragariae
(rizomas)
Verticillium dahliae
(rizomas)

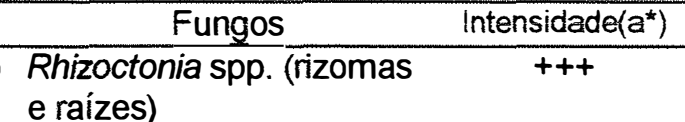

$$
\text { e raízes) }
$$

Rhizoctoniaspp. (broto,

D- Murcha geral, mais evidente nas horas mais quentes
do dia.
- Sistema radicular com desenvolvimento médio,
algumas raízes pretas, e descoloração de vasos do
nizoma, e "chocolate" no rizoma.

E- Murcha e seca progressiva das folhas velhas, folhas novas túrgidas.

- Sistema radicular pobre, com muitas raízes pretas.

Descoloração de vasos do rizoma. Algumas plantas com lesões "chocolate" no rizoma.

F- Plantas subdesenvolvidas, com avemelhamento e necrose da base dos pecíolos, folhas novas normais.

- Sistema radicular pobre, muitas raízes pretas. Lesões necróticas marrom-avemelhadas ao longo das laterais Rhizoctonia spp. (brotos,
raizes e rizomas) Rhizoctonia spp. (raízes e +++ rizomas) Fusarium spp. (raizes) + Pythium spp. (raizes) + do rizoma, principalmente nos pontos de inserção das raízes.

\begin{tabular}{|c|c|c|}
\hline $\begin{array}{l}\text { G- Folhas jovens de tamanho reduzido; seca das folhas } \\
\text { velhas, com ou sem avermelhamento dos peciolos. } \\
\text { - Sistema radicular com desenvolvimento médio, } \\
\text { algumas raízes pretas. Algumas plantas com lesão } \\
\text { "chocolate" no rizoma. }\end{array}$ & $\begin{array}{l}\text { Colletotrichum fragariae } \\
\text { (rizomas) } \\
\text { Rhizoctonia spp. (raízes) }\end{array}$ & $\begin{array}{l}++ \\
++\end{array}$ \\
\hline $\begin{array}{l}\text { H- Plantas subdesenvolvidas, folhas jovens de tamanho } \\
\text { reduzido, broto necrosado. }\end{array}$ & $\begin{array}{l}\text { Rhizoctonia spp. (broto e } \\
\text { rizomas) }\end{array}$ & +++ \\
\hline $\begin{array}{l}\text { - Sistema radicular com desenvolvimento médio a } \\
\text { pobre, com lesões necróticas. Rizomas com necroses. } \\
\text { Algumas plantas com lesão "chocolate". }\end{array}$ & $\begin{array}{l}\text { Colletotrichum fraganiae } \\
\text { (rizomas) } \\
\text { Fusarium spp. (raízes) }\end{array}$ & + \\
\hline
\end{tabular}

$\begin{array}{lc}\begin{array}{l}\text { Colletotrichum fragariae } \\ \text { (rizomas) }\end{array} & +++ \\ \begin{array}{l}\text { Verticillium dahliae } \\ \text { (rizomas) }\end{array} & ++ \\ \begin{array}{l}\text { Rhizoctonia spp. (raízes) } \\ \text { Fusarium spp. (raízes) }\end{array} & + \\ \begin{array}{l}\text { Verticillium dahliae } \\ \text { (rizomas) }\end{array} & + \\ \begin{array}{l}\text { Colletotrichum fraganiae } \\ \text { (rizomas) }\end{array} & ++ \\ \text { Rhizoctonia spp. (raízes) } & + \\ \begin{array}{l}\text { Rhizoctonia spp. (base dos } \\ \text { peciolos e raízes) }\end{array} & +++ \\ \text { Fusanium spp. (raizes) } & + \\ \end{array}$


De acordo com os resultados apresentados na Tabela 16, observase que o sintoma de subdesenvolvimento das plantas sempre esteve associado a Rhizoctonia, podendo ocorrer ou não outros fungos como Fusanium e Phythium. Já, quando se trata de murcha, sempre estiveram presentes Colletotrichum fraganiae, Verticillium dahliae elou Rhizoctonia spp., podendo ainda estar associado Fusarium spp.. Passos (1997) encontrou resultados semelhantes, com relação à murcha na parte aérea, e aos fungos predominantes associados aos sintomas observados, e Tanaka et al. (1995), com relação aos sintomas associados com maior freqüência ao Colletotrichum.

Ao final do experimento, no cultivo protegido, foi realizada quantificação da incidência de plantas doentes nas parcelas, por meio de notas, sendo os resultados apresentados na Tabela 17.

Tabela 17 - Avaliação da incidência média de plantas doentes por parcela $\left(a^{\star}\right)$, em $22 / 12 / 95$, no cultivo protegido, para as diferentes coberturas do solo e níveis de irrigação (MPa), em Atibaia, SP.

\begin{tabular}{lccc}
\hline Coberturas do solo & \multicolumn{3}{c}{ Níveis de inigação (MPa) } \\
\cline { 2 - 4 } & $-0,010$ & $-0,035$ & $-0,070$ \\
\hline Plástico transparente & $B$ & $B$ & $M$ \\
Plástico preto & $M$ & $M$ & $A$ \\
\hline
\end{tabular}

$a^{*}$ incidências alta $(A)$, média $(M)$ e baixa $(B)$, representam mais de $66 \%$, de 33 a $66 \%$, e menos de $33 \%$ de plantas com sintomas de doença, respectivamente.

Os resultados da Tabela 17 concordam com os observados na Tabela 14, no mês de outubro, mostrando tendência ao desenvolvimento de doenças no plástico preto e no nível de água menos úmido (-0,070 MPa). 


\subsection{Desenvolvimento vegetativo}

\subsubsection{Desenvolvimento vegetativo no cultivo a campo aberto}

Para estudo do desenvolvimento vegetativo, foram realizadas amostragens de plantas por ocasião das 4 floradas, no campo aberto, para estimativa da matéria seca da parte aérea (MSPA), área foliar (AF), índice de área foliar (IAF), altura e máxima dimensão horizontal da planta (DHP). Os resultados obtidos encontram-se na Tabela 18.

Tabela 18 - Valores médios por planta da altura $(\mathrm{cm})$, máxima dimensão horizontal da planta (DHP) $(\mathrm{cm})$, matéria seca da parte aérea (MSPA) $(\mathrm{g})$, área foliar (AF) $\left(\mathrm{cm}^{2}\right)$ e índice de área foliar (IAF), obtidos nas 4 floradas, do morangueiro cultivado a campo aberto, nas diferentes coberturas do solo e níveis de irrigação (MPa), em Atibaia, SP, em 1995. a*

\begin{tabular}{|c|c|c|c|c|c|}
\hline Itens & Altura & DHP & MSPA & $A F$ & IAF \\
\hline \multicolumn{6}{|l|}{ Coberturas de solo } \\
\hline Plástico transparente & $18,9 a$ & $30,8 a$ & $17,6 \mathbf{a}$ & $1610,5 a$ & $1,79 a$ \\
\hline Plástico preto & $18,3 a$ & $31,2 \mathrm{a}$ & $17,0 a$ & $1578,4 a$ & $1,75 \mathrm{a}$ \\
\hline \multicolumn{6}{|l|}{ Niveis de imigação } \\
\hline$-0,010$ & $19,2 a$ & $31,2 a$ & $17,4 a$ & $1588,9 a$ & $1,77 a$ \\
\hline$-0,035$ & $18,6 a$ & $31,2 a$ & $17,2 a$ & $1571,5 a$ & $1,75 a$ \\
\hline$-0,070$ & $18,1 \mathrm{a}$ & $30,7 a$ & $17,2 a$ & $1622,9 a$ & $1,80 a$ \\
\hline \multicolumn{6}{|l|}{ Floradas } \\
\hline $1^{2}$ & $13,1 \mathrm{c}$ & $27,1 b$ & $9,7 \mathrm{c}$ & $1015,1 \mathrm{c}$ & $1,13 c$ \\
\hline $2^{a}$ & $18,1 b$ & $32,9 a$ & $16,4 b$ & $1418,4 b$ & $1,58 b$ \\
\hline $3^{\mathrm{a}}$ & $20,9 a$ & $32,8 a$ & $25,4 a$ & $2006,6 a$ & $2,23 a$ \\
\hline $4^{a}$ & $22,3 a$ & $31,3 a$ & $17,7 \mathrm{~b}$ & $1937,7 a$ & $2,15 a$ \\
\hline $\mathrm{C} v_{\text {parcela }}(\%)$ & 7,7 & 4,9 & 12,4 & 11,9 & 11,9 \\
\hline CV $V_{\text {sub-parcela }}(\%)$ & 13,0 & 8,8 & 14,8 & 15,1 & 15,1 \\
\hline
\end{tabular}

$\mathrm{a}^{*}$ dentro de cada ítem e de cada variável, as médias seguidas pela mesma letra não diferem entre si pelo teste de Tukey $(P<0,05)$.

As interações entre os níveis de irrigação e as coberturas de solo, niveis de irrigação e épocas (floradas), coberturas de solo e épocas, não foram significativas, para as variáveis avaliadas (Tabela 18). Não houve efeito das coberturas do solo e dos níveis de irrigação para as variáveis analisadas. 
A ausência de efeito dos niveis de irrigação, no desenvolvimento das plantas, esteve, provavelmente, associada às precipitações naturais ocorridas durante a experimentação (Tabela 4).

Foram observadas diferenças significativas no desenvolvimento vegetativo, com relação à época de amostragem (Tabela 18). Os valores de altura das plantas, área foliar e IAF foram significativamente superiores na $3^{\mathrm{a}}$ e $4^{\mathrm{a}}$ floradas, quando comparados aos valores obtidos nas outras floradas. Para todas as variáveis, na $1^{\text {a }}$ florada, foram observados os menores valores, e o pico do desenvolvimento foi atingido na $3^{\mathrm{a}}$ florada, exceto para altura e DHP da planta. A ocorrência dos valores de pico da MSPA, AF e IAF, antes do final do ciclo, com posterior queda, como observado na Tabela 18, é semelhante aos resultados obtidos por Lucchesi \& Minami (1980) e Olitta (1980), para as condições de Piracicaba. Entretanto, difere dos apresentados por Tessarioli Neto (1993), em Monte Alegre do Sul, que observou aumento dos valores dessas variáveis até o final do ciclo da cultura. A ocorrência de doenças no campo aberto (Tabela 16) pode ter favorecido a diminuição da MSPA na $4^{a}$ florada (Tabela 18). Os valores da máxima dimensão horizontal das plantas, observados na Tabela 18, são semelhantes aos apresentados por Camargo et al. (1974), para o mesmo cultivar em Jundiaí, porém diferem com relação à altura da planta, sendo cerca de $30 \%$ acima do obtido por esses autores.

Com relação à MSPA, os valores observados na Tabela 18 são superiores aos obtidos por Lucchesi \& Minami (1980), principalmente nas primeiras floradas. O cultivar utilizado foi o mesmo (Campinas), entretanto essas diferenças podem estar associadas ao maior espaçamento das plantas $(35 \times 35 \mathrm{~cm})$ e à cobertura do solo (farpas de madeira) utilizada por esses autores. A partir de outubro, os resultados de MSPA (Tabela 18), foram semelhantes aos apresentados por Tessarioli Neto (1993), que também utilizou o cv. Campinas e o plástico preto como cobertura do canteiro. 
Com relação a área foliar e IAF, os valores apresentados na Tabela 18 foram superiores aos obtidos por Tessarioli Neto (1993) e Lucchesi \& Minami (1980). Tessarioli Neto (1993) obteve valores de área foliar variando de 909 a $1726 \mathrm{~cm}^{2}$, no período de 9 de setembro a 2 de dezembro, valores estes menores que os observados na Tabela 18 . Com relação a variação do IAF, Lucchesi \& Minami (1980) relatam valores de 0,2 a 1,3 durante o ciclo do morangueiro, que foram bem menores que os obtidos neste trabalho, no cultivo a campo aberto (Tabela 18).

As medidas da área foliar, IAF, MSPA, altura e máxima dimensão horizontal da planta, são importantes para caracterizar o desenvolvimento vegetativo das plantas.

\subsubsection{Desenvolvimento vegetativo no cultivo protegido}

As plantas no cultivo protegido atingiram a $1^{a}$ época de amostragem ( $1^{\mathrm{a}}$ florada), antes do início da diferenciação dos tratamentos (final de maio). Para caracterizar o desenvolvimento vegetativo nessa fase, foram medidas altura, máxima dimensão horizontal da planta (DHP), e estimada área foliar (AF) e índice de área foliar (IAF), de 25 plantas no experimento. Para as variáveis avaliadas foram obtidas as seguintes médias (e respectivos desvios padrões): altura 10,4 cm $(1,5 \mathrm{~cm})$; máxima dimensão horizontal da planta $25,0 \mathrm{~cm}(3,1 \mathrm{~cm})$; área foliar 717,2 $\mathrm{cm}^{2}\left(232,3 \mathrm{~cm}^{2}\right)$ e IAF $0,797(0,258)$.

A altura, máxima dimensão horizontal, área foliar e IAF das plantas, obtidos na $2^{\mathrm{a}}$ e na $3^{\mathrm{a}}$ florada, nas diferentes coberturas do solo e níveis de irrigação, encontram-se na Tabela 19. 
Tabela 19 - Valores médios por planta da altura $(\mathrm{cm})$, máxima dimensão horizontal da planta (DHP) $(\mathrm{cm})$, estimativas da área foliar (AF) $\left(\mathrm{cm}^{2}\right)$ por planta $e$ índice de área foliar (IAF) do morangueiro no cultivo protegido, nas diferentes coberturas do solo e níveis de irrigação (MPa), ocorridos na $2^{\mathrm{a}}$ e na $3^{\mathrm{a}}$ florada, em Atibaia, SP, em 1995. $a^{*}$

\begin{tabular}{lcccc}
\hline Itens & Altura & DHP & AF & IAF \\
\hline Coberturas do solo & & & & \\
Plástico transparente & $21,4 a$ & $30,3 a$ & $2561,8 \mathrm{a}$ & $2,85 \mathrm{a}$ \\
Plástico preto & $18,9 \mathrm{~b}$ & $28,3 \mathrm{~b}$ & $2015,0 \mathrm{~b}$ & $2,24 \mathrm{~b}$ \\
\hline Níveis de irrigação & & & & \\
$-0,010$ & 21,8 & $31,0 \mathrm{a}$ & $2597,8 \mathrm{a}$ & $2,89 \mathrm{a}$ \\
$-0,035$ & 20,5 & $29,5 \mathrm{ab}$ & $2420,2 \mathrm{ab}$ & $2,69 \mathrm{ab}$ \\
$-0,070$ & 18,2 & $27,5 \mathrm{~b}$ & $1847,2 \mathrm{~b}$ & $2,05 \mathrm{~b}$ \\
\hline Floradas & & & & \\
$2^{\mathrm{a}}$ & 20,2 & $29,6 \mathrm{a}$ & $2338,5 \mathrm{a}$ & $2,60 \mathrm{a}$ \\
$3^{\mathrm{a}}$ & 20,1 & $29,0 \mathrm{a}$ & $2238,3 \mathrm{a}$ & $2,49 \mathrm{a}$ \\
\hline $\mathrm{CV}_{\text {parcela }}(\%)$ & 12,3 & 7,9 & 29,2 & 29,2 \\
$\mathrm{CV}_{\text {subparcele }}(\%)$ & 16,2 & 14,1 & 29,9 & 29,9 \\
\hline
\end{tabular}

$\mathrm{a}^{*}$ dentro de cada ítem e de cada variável, as médias seguidas pela mesma letra não diferem entre si pelo teste de Tukey $(P<0,05)$.

Com relação à altura das plantas, só foi significativa a interação entre níveis de água e épocas (floradas). $\mathrm{Na} 2^{\mathrm{a}}$ florada, não houve efeito dos níveis de água sobre a altura. Porém, na $3^{\mathrm{a}}$ florada, as alturas medidas nos potenciais de água no solo -0,010 e -0,035 MPa foram significativamente maiores, na ordem de $38 \%$ e $22 \%$, respectivamente, que as observadas no potencial $-0,070 \mathrm{MPa}$. Na $3^{\mathrm{a}}$ florada, a altura foi significativamente superior à obtida na $2^{\mathrm{a}}$ florada, no nível de irrigação de $-0,010 \mathrm{MPa}$, com aumento de $14 \%$. Por outro lado, no nível de água de $-0,070 \mathrm{MPa}$, ocorreu o inverso, a menor altura foi observada na $3^{\mathrm{a}}$ florada. Essa redução na altura das plantas foi de $16 \%$, e pode estar associada, a incidência de doenças nesse nivel de irrigação (Tabela 14).

As interações entre níveis de irrigação e cobertura de solo, níveis de irrigação e épocas (floradas), coberturas de solo e épocas, para as variáveis DHP, AF e IAF não foram significativas.

De acordo com os resultados apresentados na Tabela 19, o plástico transparente favoreceu significativamente o desenvolvimento das plantas (DHP, 
AF e (AF). Com relação aos níveis de irrigação, observou-se diferença significativa favorável ao nível de $-0,010 \mathrm{MPa}$, quando comparado ao nível de -0,070 $\mathrm{MPa}$. $\mathrm{O}$ nivel de -0,035 MPa não diferiu significativamente dos demais. Possivelmente, o maior intervalo, o menor número e a menor lâmina de irrigação, ocorridos no tratamento mais seco $(-0,070 \mathrm{MPa})$ (Tabelas 5 e 7$)$, afetaram o desenvolvimento das plantas. No cultivo protegido, onde não ocorreram precipitações, foi possivel verificar os efeitos dos níveis de irrigação no desenvolvimento vegetativo do morangueiro (Tabela 19). O efeito dos niveis de irrigação no IAF, observado na Tabela 19, são semelhantes aos apresentados por Serrano et al. (1992). Com relação à cobertura do solo, verifica-se que os resultados obtidos no cultivo protegido (Tabela 19) e no campo aberto (Tabela 18), diferiram. Essas diferenças devem estar associadas ao comportamento fitossanitário das plantas nos dois ambientes (Tabelas 14, 15 e16), e à temperatura do solo. No cultivo protegido sob plástico transparente, as temperaturas máximas do solo foram em média $2,6^{\circ} \mathrm{C}$ e $1,6^{\circ} \mathrm{C}$ menores que as observadas sob o plástico preto, nos níveis de água de $-0,035$ e -0,070 MPa, respectivamente, e semelhantes nos dois plásticos no nível mais úmido (Figura 3). A ocorrência de menores temperaturas máximas do solo sob plástico transparente pode ter favorecido o desenvolvimento vegetativo nessa cobertura (Galletta \& Bringhurst, 1990). No campo aberto, apesar das diferenças de temperatura máxima do solo, observadas entre as duas coberturas (Figura 5), as precipitações podem ter sido preponderantes na homogenização dos tratamentos avaliados.

$O$ efeito da época de amostragem ( $2^{\mathrm{a}}$ e $3^{\mathrm{a}}$ florada) não foi significativo no cultivo protegido (Tabela 19). Apesar disso, nota-se tendência de que o pico, no desenvolvimento vegetativo no cultivo protegido, tenha ocorrido na $2^{\mathrm{a}}$ florada. No cultivo a campo aberto (Tabela 18 ) houve predominância de pico na $3^{\mathrm{a}}$ florada. Entretanto, ocorreu um número maior de floradas no campo aberto. $\mathrm{O}$ cultivo protegido antecipou a $1^{\text {a }}$ florada cerca de 15 dias e reduziu o número de floradas. Considerando-se todas as floradas ocorridas nos dois ambientes de 
cultivo, a $\mathrm{AF}$ e o IAF foram, em média $10 \%$ maiores no cultivo protegido. Entretanto, há que se considerar as diferenças metodológicas nas estimativas destas variáveis, nos dois ambientes de cultivo.

\subsubsection{Avaliação final do desenvolvimento vegetativo}

Ao término do experimento, realizou-se a avaliação final do desenvolvimento vegetativo das plantas nos dois experimentos (cultivo protegido $\mathrm{e}$ campo aberto, aos 247 dias após o plantio). Os resultados obtidos encontram-se nas Tabelas 20 e 21.

A interação entre as coberturas do solo e os niveis de irrigação não foi significativa para nenhuma das variáveis analisadas (MSPA, MSPS, AF e IAF) nos dois ambientes de cultivo.

No cultivo protegido não foram observadas diferenças significativas nas variáveis MSPS, MSPA, AF e IAF, com relação às coberturas do solo (Tabela 20). Também não houve efeito dos niveis de irrigação no MSPS. Por outro lado, ocorreram diferenças significativas nas variáveis MSPA, AF e IAF, com relação aos niveis de irrigação. Os resultados obtidos para estas 3 variáveis foram cerca de $66 \%$ maiores no nível de irrigação $-0,010 \mathrm{MPa}$, quando comparados aos obtidos no nível $-0,070 \mathrm{MPa}$. Os valores obtidos no nivel intermediário de água não diferiram significativamente dos demais.

Os resultados obtidos no cultivo protegido na Tabela 20, concordam com os apresentados na Tabela 19, com relação aos níveis de irrigação e diferem quanto ao efeito da cobertura do solo. No cultivo protegido, os níveis de irrigação com melhor desenvolvimento das plantas (Tabela 20) estão relacionados ao menor número de plantas doentes (Tabela 14) e às menores temperaturas do solo (Figura 4). Passos (1997) também observou que, em tratamentos com menor temperatura do solo, a ocorrência de doenças foi menor e o desenvolvimento vegetativo maior. 
Entretanto, convém salientar que na $2^{a}$ florada, as plantas no cultivo protegido ainda estavam em bom estado de sanidade. Portanto, o efeito de redução, no desenvolvimento vegetativo, nas parcelas menos úmidas, deve estar relacionado à diminuição do número e da lâmina de água e ao aumento do intervalo entre irrigações.

Tabela 20- Valores médios da matéria seca da parte subterrânea (MSPS) em g, matéria seca da parte aérea (MSPA) em g, área foliar (AF) em $\mathrm{cm}^{2}$ por planta, e índice de área foliar (IAF) do morangueiro no cultivo protegido, nas diferentes coberturas de solo e niveis de irrigação (MPa), em 23/12/95 em Atibaia, SP. a*

\begin{tabular}{lcccc}
\hline \multicolumn{1}{c}{ Itens } & MSPS & MSPA & AF & IAF \\
\hline Coberturas do solo & & & & \\
Plástico transparente & $11,7 \mathrm{a}$ & $15,1 \mathrm{a}$ & $1703,1 \mathrm{a}$ & $1,89 \mathrm{a}$ \\
Plástico preto & $11,9 \mathrm{a}$ & $11,7 \mathrm{a}$ & $1291,8 \mathrm{a}$ & $1,44 \mathrm{a}$ \\
\hline Niveis de imigação & & & & \\
$-0,010$ & $11,9 \mathrm{a}$ & $16,9 \mathrm{a}$ & $1934,8 \mathrm{a}$ & $2,15 \mathrm{a}$ \\
$-0,035$ & $12,3 \mathrm{a}$ & $13,3 \mathrm{ab}$ & $1392,7 \mathrm{ab}$ & $1,55 \mathrm{ab}$ \\
$-0,070$ & $11,1 \mathrm{a}$ & $10,1 \mathrm{~b}$ & $1164,9 \mathrm{~b}$ & $1,29 \mathrm{~b}$ \\
\hline CV $(\%)$ & 22,1 & 35,6 & 38,1 & 38,1 \\
\hline
\end{tabular}

$\overline{\mathrm{a}}^{\star}$ dentro de cada ítem, e de cada variável, as médias seguidas pela mesma letra não diferem entre si pelo teste de Tukey $(P<0,05)$.

Tabela 21- Valores médios da matéria seca da parte subterrânea (MSPS) em g, matéria seca da parte aérea (MSPA) em g, área foliar (AF) em $\mathrm{cm}^{2}$ por planta, e índice de área foliar (IAF) do morangueiro cultivado a campo aberto, nas diferentes coberturas de solo e níveis de irrigação (MPa), em 23/12/95 em Atibaia, SP. a*

\begin{tabular}{lcccc}
\hline \multicolumn{1}{c}{ Ítens } & MSPS & MSPA & AF & IAF \\
\hline Coberturas do solo & & & & \\
Plástico transparente & $12,2 a$ & $18,4 a$ & $1777,3 a$ & $1,98 a$ \\
Plástico preto & $12,2 a$ & $15,9 a$ & $1562,2 a$ & $1,74 a$ \\
\hline Niveis de imigação & & & & \\
$-0,010$ & $12,0 a$ & $17,5 a$ & $1751,3 a$ & $1,95 a$ \\
$-0,035$ & $12,2 a$ & $16,7 a$ & $1627,8 a$ & $1,81 a$ \\
$-0,070$ & $12,5 a$ & $17,2 a$ & $1630,3 a$ & $1,81 a$ \\
\hline CV $(\%)$ & 20,1 & 27,8 & 28,8 & 28,8 \\
\hline
\end{tabular}

$\mathrm{a}^{*}$ dentro de cada ítem, e de cada variável, as médias seguidas pela mesma letra não diferem entre si pelo teste de Tukey $(P<0,05)$. 
No cultivo a campo aberto (Tabela 21), não houve efeito das coberturas do solo nem dos níveis de irrigação, em nenhuma das variáveis estudadas. A ocorrência de doenças de forma homogênea nas parcelas do campo aberto, desde junho, possivelmente contribuiu para não terem sido observadas diferenças significativas nas variáveis estudadas. Os resultados da Tabela 21 concordam com os obtidos nas 4 floradas, apresentados na Tabela 18.

Os valores da MSPS são semelhantes nos dois ambientes de cultivo (Tabelas 20 e 21), exceto para o nível de água de -0,070 MPa, onde no campo aberto o valor é $11,6 \%$ superior ao obtido no cultivo protegido.

$\mathrm{Na}$ última avaliação, os valores da MSPA foram maiores nas plantas do cultivo a campo aberto, quando comparados ao cultivo protegido, com aumento de aproximadamente 22 e $36 \%$, com relação ao plástico transparente e preto, respectivamente. Com relação aos níveis de água -0,010, -0,035 e -0,070 MPa os aumentos foram de 4, 24 e 70 \%, respectivamente (Tabelas 20 e 21). Essa redução da matéria seca da parte aérea, observada no cultivo protegido em relação ao cultivo a campo aberto, pode estar relacionada às diferenças climáticas envolvidas nos dois ambientes de cultivo. luchi (1993) também observou menor desenvolvimento vegetativo do morangueiro, em cultivo protegido, em Viçosa, MG, quando comparado às condições de campo aberto.

\subsubsection{Correlações simples das variáveis de desenvolvimento vegetativo no final do ciclo}

A Tabela 22 apresenta os coeficientes de correlação simples (r) entre a matéria seca da parte aérea (MSPA), a matéria seca da parte subterrânea (MSPS) e o índice de área foliar (IAF) das plantas coletadas no dia 23 de dezembro de 1995, nos dois ambientes de cultivo. 
Tabela 22- Coeficientes de correlação simples ( $r$ ) entre a matéria seca da parte aérea (MSPA), matéria seca da parte subterrânea (MSPS) e índice de área foliar (IAF), observados no morangueiro, em 23/12/95, em Atibaia, $\mathrm{SP}$, em diferentes níveis de água (MPa) e coberturas do solo (plástico transparente e preto) no cultivo protegido e em campo aberto.

\begin{tabular}{|c|c|c|c|c|c|c|c|}
\hline \multirow{2}{*}{$\begin{array}{c}\text { Coberturas } \\
\text { do } \\
\text { solo }\end{array}$} & \multirow{2}{*}{$\begin{array}{c}\text { Níveis } \\
\text { de } \\
\text { água }\end{array}$} & \multicolumn{3}{|c|}{ Cultivo protegido } & \multicolumn{3}{|c|}{ Campo aberto } \\
\hline & & $\begin{array}{c}\text { MSPA } \\
\text { MSPS }\end{array}$ & $\begin{array}{c}\text { MSPA e } \\
\text { IAF }\end{array}$ & $\begin{array}{c}\text { MSPSe } \\
\text { IAF }\end{array}$ & $\begin{array}{c}\text { MSPA } \\
\text { MSPS }\end{array}$ & $\begin{array}{c}\text { MSPA e } \\
\text { IAF }\end{array}$ & $\begin{array}{c}\text { MSPSe } \\
\text { IAF }\end{array}$ \\
\hline \multirow[t]{3}{*}{ PT } & $-0,010$ & 0,4298 & $0,9864^{\star \star}$ & 0,4168 & $\overline{0,5452^{*}}$ & $0,9574^{\star \star}$ & 0,4934 \\
\hline & $-0,035$ & $0,6390^{*}$ & $0,9567^{\star \star}$ & $0,6298^{*}$ & 0,4728 & $0,9621^{\star \star}$ & $0,5569^{*}$ \\
\hline & $-0,070$ & $0,6450^{\star \star}$ & $0,9793^{\star \star}$ & $0,6807^{\star \star}$ & 0,4889 & $0,9816^{\star \star}$ & 0,4296 \\
\hline \multirow[t]{3}{*}{$\mathrm{PP}$} & $-0,010$ & $0,8148^{\star \star}$ & $0,9793^{\star \star}$ & $0,7912^{\star \star}$ & $0,5458^{\star}$ & $0,9585^{\star \star}$ & $0,5862^{*}$ \\
\hline & $-0,035$ & $0,7973^{\star \star}$ & $0,9875^{\star \star}$ & $0,7421^{\star \star}$ & $0,7681^{\star \star}$ & $0,9767^{\star *}$ & $0,7888^{\star \star}$ \\
\hline & $-0,070$ & $0,5490^{\star}$ & $0,9864^{\star *}$ & $0,5387^{\star}$ & $0,7353^{\star \star}$ & $0,9431^{\star \star}$ & $0,6669^{\star \star}$ \\
\hline
\end{tabular}

* correlações significativas a $5 \%$ de probabilidade.

** correlações significativas a $1 \%$ de probabilidade.

De um modo geral, observa-se que as correlações entre a MSPA e MSPS, e MSPS e IAF alcançaram maiores valores e maior número de casos significativos no cultivo com plástico preto, quando comparado ao transparente.

Entre a MSPA e o IAF, as correlações foram significativas a $1 \%$ de probabilidade no campo aberto e cultivo protegido, nas diferentes coberturas e níveis de irrigação adotados. Além de serem significativas, os parâmetros se mostraram bem correlacionados.

Com relação às correlações entre MSPS e IAF, nota-se que não ocorreu significância no nível -0,010 $\mathrm{MPa}$ no plástico transparente, nos dois ambientes de cultivo e no nível -0,070 MPa no campo aberto. Essas variávies não se correlacionaram bem.

No cultivo protegido, as correlações entre a MSPA e MSPS só não foram significativas no plástico transparente, com nível de água -0,010 $\mathrm{MPa}$, e, no campo aberto, nos níveis -0,035 e -0,070 MPa. Apesar das correlações terem sido significativas nos demais tratamentos, os valores de $r$ foram variávies e, na maioria dos casos, não se correlacionaram bem. 
Esses resultados diferem do apresentado por Passos (1997), que obteve melhores correlações. Possivelmente, os tratamentos realizados, os tipos de doenças, o nível de intensidade e a época de ocorrência, observados no presente trabalho e no de Passos (1997), tenham influenciado os valores de $r$, bem como o nível de significância, contribuindo para essa diferença.

\subsection{Resistência estomática}

As medições com porômetro de equilíbrio dinâmico foram realizadas, em seqüência de dias ensolarados e secos, sempre ao meio dia (12 horas). No período de avaliação da resistência estomática, as irrigações foram sempre realizadas no período da tarde, após as determinações.

A Tabela 23 apresenta os valores médios de resistência estomática no dia da irrigação, antes da realização da mesma e no dia subsequente. No campo aberto, as medições em todos os tratamentos foram realizadas nos dias 29 e 30 de agosto. Já no cultivo protegido, no nível de água -0,010 $\mathrm{MPa}$, as determinações ocorreram nos dias 29 e 30 de agosto e, no nível -0,070 MPa, dias 31 de agosto e $1^{\circ}$ de setembro.

Observando-se os resulta dos da Tabela 23, nota-se que à medida que os tratamentos se tornam mais secos, a resistência estomática tende a aumentar. Analisando-se os resultados obtidos por intervalo de confiança da média a $5 \%$ de probabilidade, observou-se que, no nível de água $-0,010 \mathrm{MPa}$, os valores de resistência estomática não diferiram entre si, comparando-se as medições realizadas no dia da irrigação e no dia subsequente, nos dois ambientes de cultivo. Nos demais níveis de água, a diferença da resistência estomática, antes e depois da irrigação, foi significativa nos dois ambientes de cultivo, nas duas coberturas de solo. Um dia após as irrigações, em todos os 
tratamentos avaliados, nos dois ambientes de cultivo, não foram observadas diferenças significativas na resistência estomática. No campo aberto, no dia da irrigação, só foi observada diferença significativa entre os níveis $-0,010$ e $-0,070 \mathrm{MPa}$, no plástico preto.

Tabela 23- Valores médios de resistência estomática $\left(\mathrm{s} . \mathrm{cm}^{-1}\right)$ no morangueiro, observados no dia em que a irrigação era necessária, antes da aplicação de água e no dia seguinte, no cultivo protegido e campo aberto em Atibaia, SP, em diferentes coberturas do solo e níveis de água.

\begin{tabular}{|c|c|c|c|}
\hline \multirow{2}{*}{$\begin{array}{c}\text { Coberturas } \\
\text { do solo }\end{array}$} & \multirow{2}{*}{$\begin{array}{c}\text { Níveis de } \\
\text { água }(\mathrm{MPa})\end{array}$} & \multicolumn{2}{|c|}{ Resistência estomática $\left(\mathrm{s} . \mathrm{cm}^{-1}\right)$} \\
\hline & & Dia da irrigação & Um dia após a irrigação \\
\hline \multicolumn{4}{|c|}{ CULTIVO PROTEGIDO } \\
\hline \multirow[t]{2}{*}{ Plástico preto } & $-0,010$ & 1,089 & 1,002 \\
\hline & $-0,070$ & 1,399 & 0,974 \\
\hline Plástico transparente & $-0,070$ & 1,409 & 1,027 \\
\hline \multicolumn{4}{|c|}{ CAMPO ABERTO } \\
\hline \multirow[t]{3}{*}{ Plástico preto } & $-0,010$ & 1,391 & 1,198 \\
\hline & $-0,035$ & 1,566 & 1,278 \\
\hline & $-0,070$ & 1,738 & 1,110 \\
\hline Plástico transparente & $-0,070$ & 1,732 & 1,162 \\
\hline
\end{tabular}

Serrano et al. (1992) não observaram diferenças significativas na resistência estomática do morangueiro cv. Chandler, entre tratamentos de níveis de água no solo, semelhantes aos adotados no presente estudo. No entanto, os autores não esclarecem quando as medições foram realizadas, antes ou após as irrigações. luchi (1993) encontrou aumento da resistência estomática em morangueiro cv. Campinas, comparando tratamento com umidade do solo, na capacidade de campo, com diferentes niveis de déficit hídrico de moderado a severo (as irrigações eram realizadas quando o potencial de água no solo atingia -0,4 e -1,2 MPa, respectivamente). Os níveis de estresse impostos foram bem maiores que os utilizados no presente trabalho. 


\subsection{Produção}

A produção e seus componentes foram analisados pelos valores totais observados, assim como por épocas diferenciadas durante o ciclo da cultura. A produção de frutos não comerciáveis foi muito baixa, menor que $1 \%$, no cultivo a campo aberto, e praticamente inexistente, no cultivo protegido.

A produção de frutos comerciáveis por época, nos experimentos, em cultivo protegido e a campo aberto, encontra-se nas Tabelas 24 e 25 .

A interação entre coberturas do solo e niveis de água não foi significativa para a produção de frutos, por época, nos dois ambientes estudados. No campo aberto também não foi significativa a interação entre níveis de água e épocas.

No cultivo protegido, as coberturas do solo afetaram significativamente a distribuição da produção ao longo do ciclo da cultura (Tabela 24). Nos meses de agosto (E2) e outubro (E4), no plástico transparente, a produção de frutos foi significativamente maior que a observada no plástico preto. Dessa forma, observa-se que o plástico preto promoveu concentração da produção em setembro (E3), enquanto que, no transparente, a produção foi melhor distribuída de agosto a setembro (Tabela 24). Martins (1983) também observou tendência de aumento de produção do morangueiro cv. Campinas, até meados de outubro, com plástico transparente, quando comparado aos plásticos preto, azul translúcido e solo descoberto. A melhor distribuição da produção pode favorecer ao ganho de capital do produtor, pois possibilita comercialização em épocas diferentes. 
Tabela 24 - Produção média de frutos comerciáveis em gramas por planta, por época $\left(a^{*}\right)$, obtida no cultivo protegido, nas diferentes coberturas do solo e níveis de irrigação (MPa), em 1995, em Atibaia, SP. b*

\begin{tabular}{|c|c|c|c|c|c|c|}
\hline \multirow{2}{*}{ İtens } & \multicolumn{6}{|c|}{ Épocas } \\
\hline & E1 & E2 & E3 & E4 & E5 & E6 \\
\hline \multicolumn{7}{|l|}{ Coberturas do solo } \\
\hline Plástico transparente & $117,9 \mathrm{Ab}$ & $153,5 \mathrm{Aab}$ & $192,1 \mathrm{Aa}$ & $126,2 \mathrm{Ab}$ & $44,0 \mathrm{Ac}$ & $20,8 \mathrm{Ac}$ \\
\hline Plástico preto & $103,9 \mathrm{Ab}$ & $99,2 \mathrm{Bb}$ & $173,4 \mathrm{Aa}$ & $71,3 \mathrm{Bbc}$ & $31,4 \mathrm{Acd}$ & $14,1 \mathrm{Ac}$ \\
\hline \multicolumn{7}{|l|}{ Níveis de Irrigação } \\
\hline$-0,010$ & $116,3 \mathrm{Ab}$ & $150,1 \mathrm{Ab}$ & $203,7 \mathrm{Aa}$ & $123,3 \mathrm{Ab}$ & $46,8 \mathrm{Ac}$ & $22,3 \mathrm{Ac}$ \\
\hline$-0,035$ & $112,7 \mathrm{Ab}$ & $128,1 \mathrm{ABb}$ & $188,7 \mathrm{ABa}$ & $109,0 \mathrm{Ab}$ & $37,4 \mathrm{Ac}$ & $16,8 \mathrm{Ac}$ \\
\hline$-0,070$ & $103,6 \mathrm{Ab}$ & $100,9 \mathrm{Bb}$ & $155,9 \mathrm{Ba}$ & $64,0 \mathrm{Bbc}$ & $28,9 \mathrm{Acd}$ & $13,4 \mathrm{AC}$ \\
\hline
\end{tabular}

$a^{*}$ os valores médios apresentados nas épocas E1, E2, E3, E4, E5 e E6, correspondem ao somatório obtido nos meses: junho+julho (produção precoce), agosto, setembro, outubro, novembro e dezembro, respectivamente.

$\mathrm{b}^{*}$ as médias dentro de cada ítem seguidas pela mesma letra (maiúscula na vertical e minúscula na horizontal) não diferem entre si pelo teste de Tukey $(P<0,05)$.

Tabela 25 - Produção média de frutos comerciáveis em gramas por planta, por época $\left(a^{*}\right)$, obtida no cultivo a campo aberto, nas diferentes coberturas do solo e níveis de irrigação (MPa), em 1995, em Atibaia, SP. b*

\begin{tabular}{|c|c|c|c|c|c|c|}
\hline \multirow[t]{2}{*}{ itens } & \multicolumn{6}{|c|}{ Épocas } \\
\hline & E1 & E2 & E3 & E4 & E5 & E6 \\
\hline \multicolumn{7}{|l|}{ Coberturas do solo } \\
\hline Plástico transparente & $90,6 \mathrm{Ac}$ & $224,8 \mathrm{Aa}$ & $119,1 \mathrm{Bc}$ & $170,0 \mathrm{Ab}$ & $36,1 \mathrm{Ad}$ & $15,7 \mathrm{Ad}$ \\
\hline Plástico preto & $80,4 \mathrm{AC}$ & $202,1 \mathrm{Aa}$ & $149,8 \mathrm{Ab}$ & $147,0 \mathrm{Ab}$ & $47,1 \mathrm{Acd}$ & $14,2 \mathrm{Ad}$ \\
\hline \multicolumn{7}{|l|}{ Níveis de Irrigação } \\
\hline$-0,010$ & $82,3 \mathrm{Ac}$ & $212,3 \mathrm{Aa}$ & $131,7 \mathrm{Ab}$ & $152,5 \mathrm{Ab}$ & $36,1 \mathrm{Ad}$ & $14,9 \mathrm{Ad}$ \\
\hline$-0,035$ & $88,7 \mathrm{Ac}$ & $209,1 \mathrm{Aa}$ & $145,0 \mathrm{Ab}$ & $159,7 \mathrm{Ab}$ & $41,9 \mathrm{Ad}$ & $14,9 \mathrm{Ad}$ \\
\hline$-0,070$ & $85,5 \mathrm{Ac}$ & $218,9 \mathrm{Aa}$ & $126,5 \mathrm{Ab}$ & $163,2 \mathrm{Ab}$ & $46,9 \mathrm{Ad}$ & $15,1 \mathrm{Ad}$ \\
\hline \multicolumn{7}{|c|}{$\begin{array}{l}C V_{\text {parcela }}=9,3 \% \text { } C V_{\text {sub-parcela }}=18,7 \% \\
a^{*} \text { os valores médios apresentados nas épocas E1, E2, E3, E4, E5 e E6, correspondem ao } \\
\text { somatório obtido nos meses: junho+julho (produção precoce), agosto, setembro, outubro, } \\
\text { novembro e dezembro, respectivamente. } \\
b^{*} \text { as médias, dentro de cada ítem seguidas pela mesma letra (maiúscula na vertical e } \\
\text { minúscula na horizontal) não diferem entre si pelo teste de Tukey }(P<0,05) \text {. }\end{array}$} \\
\hline
\end{tabular}

Nas condições de cultivo protegido, o nível de irrigação de $-0,010$ MPa favoreceu significativamente a produção de frutos nos meses de agosto (E2), setembro (E3) e outubro (E4), quando comparado ao nível de $-0,070 \mathrm{MPa}$ 
(Tabela 24). O nível de água intermediário diferiu significativamente do $-0,070$ MPa apenas em outubro (E4). Nos três niveis de irrigação, houve efeito das épocas na produção de frutos, com pico em setembro (E3). A menor produção foi observada em dezembro (E6), seguido pelo mês de novembro (E5). Convém lembrar que no cultivo protegido, por ocasião da $1^{\text {a }}$ florada, os tratamentos de níveis de água ainda não haviam sido diferenciados. Todas as parcelas estavam sendo irrigadas, quando o potencial de água no solo atingia $-0,010$ MPa. Possivelmente isso tenha contribuido para a ausência de diferenças significativas na produção precoce $(\mathrm{E} 1)$, entre os níveis de água.

Em condições de campo aberto, ocorreu diferença significativa entre as coberturas do solo, apenas na produção de setembro (E3), sendo favorável ao plástico preto (Tabela 25). Houve efeito das épocas na produção de frutos, sendo agosto (E2) a época de maior produção, diferindo significativamente das demais. As menores produções ocorreram nos meses de dezembro e novembro, de forma similar ao observado no cultivo protegido (Tabela 24).

O pico de produção no cultivo protegido ocorreu em setembro (E3), e no cultivo a campo aberto, em agosto (Tabelas 24 e 25). Segundo Groppo \& Tessarioli Neto (1991), o cv. Campinas pode ter o pico de produção de julho a setembro, dependendo da época de plantio e das condições climáticas. Como a época de plantio foi a mesma nos 2 ambientes, possivelmente as condições climáticas foram preponderantes para que o pico de produção no campo aberto tenha sido anterior ao observado no cultivo protegido. Martins (1983) e Tessarioli Neto (1993) observaram o pico de produção de frutos em setembro, utilizando o cv. Campinas, e, após esse período, a produção foi decrescente até o final do ciclo.

A investigação da produção ao longo do ciclo da cultura é importante, pois o produto alcança preços diferentes no mercado conforme a época de produção. Agrianual (1997) apresenta os preços do morango comum 
comercializado no CEAGESP, em São Paulo, durante o ano, ocorridos no período de maio de 1992 a junho de 1997. Em média, observa-se que os melhores preços são atingidos especialmente nos meses de abril e maio. Tal fato ocorre justamente por serem esses meses de baixa oferta do produto no mercado.

Como produção precoce foi considerada aquela alcançada pelo somatório dos valores obtidos em junho e julho, conforme Camargo et al. (1974). De acordo com os resultados observados nas Tabelas 24 e 25, nenhum dos fatores estudados (coberturas do solo e níveis de irrigação) favoreceram significativamente a produção precoce. Para as condições do Peru, Franciosi et al. ${ }^{2}$, citados por Martins (1983), relataram que o uso do plástico transparente no cultivo do morangueiro favoreceu a produção precoce. No presente trabalho, embora os valores de produção precoce tenham sido maiores no cultivo com plástico transparente do que com plástico preto (Tabelas 24 e 25), as diferenças observadas não foram estatísticamente diferentes. Os valores da produção precoce foram em média $30 \%$ maiores no cultivo protegido, quando comparado aos obtidos no campo aberto (Tabelas 24 e 25), sendo a maior diferença de $41 \%$, ocorrida quando se comparam os valores obtidos no nível de irrigação de $-0,010 \mathrm{MPa}$. Nestby (1979) também observou que o cultivo protegido favoreceu a produção precoce, antecipando a colheita cerca de 1 semana, em quatro cultivares de morangueiro na Noruega, quando comparado ao cultivo a campo aberto. Essa diferença de valores de produção, nos meses com preços melhores que os subsequentes, é importante, pois melhora o retorno financeiro, contribuindo para abater os custos adicionais do cultivo protegido, em relação ao campo aberto.

A variação do peso médio dos frutos, no decorrer do ciclo produtivo do morangueiro, nos dois experimentos, encontra-se nas Tabelas 26 e 27. 
Tabela 26 - Peso médio de frutos comerciáveis (gramas/fruto), por época, ( $\left.a^{\star}\right)$, no cultivo protegido nas diferentes coberturas do solo e niveis de irrigação (MPa), em 1995, em Atibaia, SP. b*

\begin{tabular}{lcccccc}
\hline İens & \multicolumn{7}{c}{ Épocas } \\
\cline { 2 - 7 } & $\mathrm{E} 1$ & $\mathrm{E2}$ & $\mathrm{E3}$ & $\mathrm{E4}$ & $\mathrm{E5}$ & $\mathrm{E6}$ \\
\hline Coberturas do solo & & & & & & \\
Plástico transparente & $9,9 \mathrm{Aa}$ & $9,4 \mathrm{Aa}$ & $8,0 \mathrm{Ab}$ & $6,0 \mathrm{Ac}$ & $5,9 \mathrm{Ac}$ & $4,2 \mathrm{Ad}$ \\
Plástico preto & $8,8 \mathrm{Ba}$ & $8,4 \mathrm{Ba}$ & $7,2 \mathrm{Bb}$ & $5,5 \mathrm{Ac}$ & $5,7 \mathrm{Ac}$ & $4,2 \mathrm{Ad}$ \\
\hline Níveis de Irrigação & & & & & & \\
$-0,010$ & $9,6 \mathrm{Aa}$ & $9,1 \mathrm{Aab}$ & $8,1 \mathrm{Ab}$ & $6,1 \mathrm{Ac}$ & $6,1 \mathrm{Ac}$ & $4,4 \mathrm{Ad}$ \\
$-0,035$ & $9,4 \mathrm{Aa}$ & $8,9 \mathrm{Aa}$ & $7,7 \mathrm{ABb}$ & $5,9 \mathrm{ABc}$ & $5,8 \mathrm{Ac}$ & $4,0 \mathrm{Ad}$ \\
$-0,070$ & $8,9 \mathrm{Aa}$ & $8,7 \mathrm{Aa}$ & $7,0 \mathrm{Bb}$ & $5,2 \mathrm{Bcd}$ & $5,4 \mathrm{Ac}$ & $4,2 \mathrm{Ad}$ \\
\hline
\end{tabular}

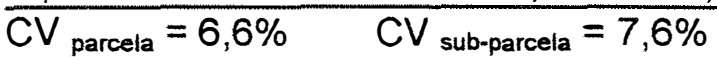

$a^{*}$ os valores médios apresentados nas épocas E1, E2, E3, E4, E5 e E6, correspondem ao somatório obtido nos meses: junho+julho, agosto, setembro, outubro, novembro e dezembro, respectivamente.

$\mathrm{b}^{*}$ as médias dentro de cada ítem seguidas pela mesma letra (maiúscula na vertical e minúscula na horizontal) não diferem entre si pelo teste de Tukey $(P<0,05)$.

Tabela 27 - Peso médio de frutos comerciáveis (gramas/fruto), por época, ( $\left.a^{\star}\right)$, no cultivo a campo aberto, nas diferentes coberturas do solo e níveis de irrigação (MPa), em 1995, em Atibaia, SP. b*

\begin{tabular}{lcccccc}
\hline İtens & \multicolumn{7}{c}{ Épocas } \\
\cline { 2 - 7 } & $\mathrm{E} 1$ & $\mathrm{E2}$ & $\mathrm{E3}$ & $\mathrm{E4}$ & $\mathrm{E5}$ & $\mathrm{E6}$ \\
\hline Coberturas do solo & & & & & & \\
Plástico transparente & $12,0 \mathrm{Aa}$ & $10,3 \mathrm{Ab}$ & $7,7 \mathrm{Ac}$ & $7,1 \mathrm{Ac}$ & $5,3 \mathrm{Ad}$ & $4,5 \mathrm{Ad}$ \\
Plástico preto & $11,8 \mathrm{Aa}$ & $10,8 \mathrm{Aa}$ & $7,8 \mathrm{Ab}$ & $7,4 \mathrm{Ab}$ & $5,7 \mathrm{Ac}$ & $5,0 \mathrm{Ac}$ \\
\hline Níveis de Irrigação & & & & & & \\
$-0,010$ & $12,1 \mathrm{Aa}$ & $10,4 \mathrm{Ab}$ & $7,7 \mathrm{Ac}$ & $7,2 \mathrm{Ac}$ & $5,5 \mathrm{Ad}$ & $4,7 \mathrm{Ad}$ \\
$-0,035$ & $11,9 \mathrm{Aa}$ & $10,8 \mathrm{Ab}$ & $7,9 \mathrm{Ac}$ & $7,3 \mathrm{Ac}$ & $5,6 \mathrm{Ad}$ & $4,8 \mathrm{Ad}$ \\
$-0,070$ & $11,8 \mathrm{Aa}$ & $10,4 \mathrm{Ab}$ & $7,7 \mathrm{Ac}$ & $7,1 \mathrm{Ac}$ & $5,4 \mathrm{Ad}$ & $4,8 \mathrm{Ad}$ \\
\hline
\end{tabular}

$\mathrm{CV}_{\text {parcela }}=5,2 \% \quad \mathrm{CV}_{\text {sub-parcela }}=7,1 \%$

$a^{*}$ os valores médios apresentados nas épocas E1, E2, E3, E4, E5 e E6, correspondem ao somatório obtido nos meses: junho+julho, agosto, setembro, outubro, novembro e dezembro, respectivamente.

$\mathrm{b}^{*}$ as médias dentro de cada ítem seguidas pela mesma letra (maiúscula na vertical e minúscula na horizontal) não diferem entre si pelo teste de Tukey $(P<0,05)$.

No cultivo protegido, para a variável peso médio dos frutos, a interação entre os niveis de irrigação e coberturas do solo não foi significativa. Conforme os resultados apresentados na Tabela 26 , observa-se que houve efeito das coberturas do solo no peso médio dos frutos, em junho+julho (E1), 
agosto (E2) e setembro (E3). Nessas épocas o plástico transparente favoreceu significativamente o peso médio dos frutos, proporcionando aumento médio de $11,8 \%$, quando comparado ao plástico preto. Com relação à variação do peso médio dos frutos durante o ciclo produtivo, ocorreram diferenças significativas entre as épocas. Nota-se que o peso médio dos frutos foi significativamente superior em junho+julho (E1) e agosto (E2), quando comparado aos meses seguintes. A partir de setembro, o peso médio dos frutos foi diminuindo até 0 final do ciclo. O nível de água -0,010 MPa favoreceu significativamente o peso médio dos frutos em setembro e outubro, quando comparado ao nível de -0,070 $\mathrm{MPa}$. O peso médio dos frutos no nível de água intermediário $(-0,035 \mathrm{MPa})$ não diferiu dos demais no decorrer do ciclo.

As interações entre niveis de irrigação e coberturas do solo, níveis de irrigação e épocas, e coberturas do solo e épocas não foram significativas para o peso médio dos frutos obtidos no cultivo a campo aberto. Houve efeito das épocas de colheita sobre o peso médio dos frutos (Tabela 27). O peso médio dos frutos foi significativamente maior nos meses de junho+julho (E1), quando comparado aos demais, exceto no plástico preto, onde o peso médio no mês de agosto não diferiu estatísticamente do período de junho e julho (E1). A partir de agosto (E2), o peso médio dos frutos foi diminuindo progressivamente até o final do experimento. Não houve efeito das coberturas do solo e dos níveis de água, no peso médio dos frutos, no cultivo a campo aberto.

O maior peso médio dos frutos, obtido com o uso do plástico transparente, no cultivo protegido (Tabela 26), quando comparado com os resultados do plástico preto, concorda com os relatos de Martins (1983), em Viamão, RS, que também utilizou o cv. Campinas. Por outro lado, difere dos resultados de Gupta \& Acharya (1993), que trabalhando com o cv. Tioga, na India, encontraram maior peso médio dos frutos com o uso do plástico preto, quando comparado ao transparente. 
O efeito dos níveis de água no peso médio dos frutos (Tabela 26) concorda com os resultados observados por Serrano et al. (1992), que encontraram maior peso médio dos frutos com potencial de água no solo de -0,010 MPa, quando comparado com o potencial de -0,070 MPa com o cv. Chandler. Ainda, com relação ao efeito de níveis de água no solo sobre o peso médio dos frutos, Blatt (1984) ressalta que irrigações aplicadas no momento adequado proporcionam aumento no peso médio dos frutos. Passos (1997), utilizando o cv. Campinas, encontrou maior peso médio dos frutos no decorrer do ciclo produtivo, nas parcelas onde a maior lâmina de irrigação foi aplicada, concordando com os resultados observados no cultivo protegido (Tabelas 5 e 26). Os resultados obtidos nas condições de campo aberto, (Tabela 27) não são concordantes com os dos autores anteriormente citados, uma vez que os níveis de água utilizados não tiveram efeito significativo sobre o peso médio dos frutos. As precipitações naturais ocorridas (Tabela 4) certamente devem ter influenciado esses resultados. Strabbioli (1988) também não encontrou variação no peso médio dos frutos em diferentes tratamentos de irrigação, e atribuiu este fato a ocorrência das precipitações.

De um modo geral, o peso médio dos frutos, no cultivo a campo aberto, foi superior ao obtido no cultivo protegido, em quase todo o ciclo (Tabelas 26 e 27). Observam-se acréscimos médios na ordem de 27,9; 18,0; 2,6; 26,3 e 11,9\% nas épocas E1, E2, E3, E4 e E6, respectivamente. Apenas na época E5 (novembro), o peso médio dos frutos foi 5,5\% maior no cultivo protegido. As maiores temperaturas máximas e amplitude térmica do ar, ocorridas no cultivo protegido ao longo do ciclo, podem ter contribuído negativamente, para que, nesse ambiente, o peso médio dos frutos tenha sido menor que no campo aberto (Tabelas 3 e 4).

A diminuição do peso médio dos frutos, no decorrer do ciclo produtivo (Tabelas 26 e 27), concorda com os resultados apresentados por outros autores (Olitta, 1980; Tessarioli Neto, 1993 e Passos, 1997). 
Olitta (1980) observou queda mais acentuada no peso médio dos frutos, desde o início até a $5^{\text {a }}$ semana de produção, e, a partir daí, queda mais lenta, com peso médio em torno de $5 \mathrm{~g} /$ fruto. Tessarioli Neto (1993), no cultivo com o plástico preto obteve peso médio dos frutos variando de 13,7 a $7,5 \mathrm{~g}$, de junho a novembro. Esses valores são semelhantes aos observados no campo aberto (Tabela 27) até outubro. Passos (1997) obteve peso médio dos frutos com sistema de irrigação por gotejamento, variando de 8,0 a 4,5 g/fruto, em ambiente protegido e a campo aberto, valores próximos aos ocorridos no cultivo protegido (Tabela 26).

A produção total, número e peso médio dos frutos ocorrido no cultivo protegido e no cultivo a campo aberto, encontram-se nas Tabelas 28 e 29.

Para as variáveis produção total, número e peso médio dos frutos, a interação entre coberturas do solo e níveis de água não foi significativa, em nenhum dos ambientes estudados.

Observando-se os resultados apresentados na Tabela 28, verifica-se que, no cultivo protegido, houve efeito da cobertura do solo e dos niveis de irrigação nas variáveis analisadas. A cobertura do solo mais favorável foi o plástico transparente, para as 3 variáveis analisadas. A produção total e o número de frutos foram significativamente maiores nos níveis de água de $-0,010$ e -0,035 MPa, quando comparados aos obtidos no nível de -0,070 MPa. Com relação ao peso médio dos frutos, o cultivo com nível de irrigação de $-0,010 \mathrm{MPa}$ resultou em valor significativamente superior ao nivel -0,070 $\mathrm{MPa}$. O nivel de -0,035 MPa não diferiu significativamente dos demais. Nota-se que a produção e seus componentes foram favorecidos nos tratamentos onde ocorreram as menores temperaturas do solo (Figuras 3 e 4), menor incidência de doenças (Tabelas 14), maior desenvolvimento vegetativo (Tabelas 19 e 20), menor intervalo entre irrigações (Tabela 7), maior número de irrigações e maior lâmina de água (Tabela 5), de forma similar ao observado por Passos (1997). 
Tabela 28 - Valores médios da produção total comerciável $(\mathrm{g})$, número de frutos e peso médio dos frutos ( $g / f r u t o$ ), por planta, no cultivo protegido nas diferentes coberturas do solo e níveis de irrigação (MPa), de junho a dezembro de 1995 em Atibaia, SP. a*

\begin{tabular}{lccc}
\hline Itens & $\begin{array}{c}\text { Produção } \\
\text { g/planta }\end{array}$ & $\begin{array}{c}\mathrm{N}^{\circ} \text { de frutos } \\
\text { por planta }\end{array}$ & $\begin{array}{c}\text { Peso médio dos frutos } \\
\text { g/fruto }\end{array}$ \\
\hline Coberturas do solo & & & \\
Plástico transparente & $654,5 \mathrm{a}$ & $85,7 \mathrm{a}$ & $7,6 \mathrm{a}$ \\
Plástico preto & $493,3 \mathrm{~b}$ & $69,5 \mathrm{~b}$ & $7,0 \mathrm{~b}$ \\
\hline Níveis de irrigação & & & \\
$-0,010$ & $662,4 \mathrm{a}$ & $86,4 \mathrm{a}$ & $7,6 \mathrm{a}$ \\
$-0,035$ & $592,6 \mathrm{a}$ & $80,1 \mathrm{a}$ & $7,4 \mathrm{ab}$ \\
$-0,070$ & $466,7 \mathrm{~b}$ & $66,4 \mathrm{~b}$ & $7,0 \mathrm{~b}$ \\
\hline $\mathrm{CV}(\%)$ & 18,9 & 7,4 & 5,5 \\
\hline $\mathrm{a}(\mathrm{s})$ & & &
\end{tabular}

$\mathrm{a}^{*}$ dentro de cada ítem, e de cada variável, as médias seguidas da mesma letra não diferem entre $s i$ pelo teste de Tukey $(P<0,05)$.

Tabela 29 - Valores médios da produção total comerciável (g), número de frutos e peso médio dos frutos (g/fruto), por planta, no cultivo a campo aberto, nas diferentes coberturas do solo e níveis de irrigação (MPa), de junho a dezembro de 1995 em Atibaia, SP. a*

\begin{tabular}{lccc}
\hline Itens & $\begin{array}{c}\text { Produção } \\
\text { g/planta }\end{array}$ & $\begin{array}{c}\mathrm{N}^{\circ} \text { de frutos } \\
\text { por planta }\end{array}$ & $\begin{array}{c}\text { Peso médio dos frutos } \\
\text { g/fruto }\end{array}$ \\
\hline Coberturas do solo & & & \\
Plástico transparente & $656,2 \mathrm{a}$ & $79,3 \mathrm{a}$ & $8,3 \mathrm{a}$ \\
Plástico preto & $640,6 \mathrm{a}$ & $75,5 \mathrm{a}$ & $8,5 \mathrm{a}$ \\
\hline Níveis de Irrigação & & & \\
$-0,010$ & $629,8 \mathrm{a}$ & $75,1 \mathrm{a}$ & $8,4 \mathrm{a}$ \\
$-0,035$ & $659,4 \mathrm{a}$ & $77,8 \mathrm{a}$ & $8,5 \mathrm{a}$ \\
$-0,070$ & $656,0 \mathrm{a}$ & $79,3 \mathrm{a}$ & $8,3 \mathrm{a}$ \\
\hline $\mathrm{CV}(\%)$ & 9,3 & 4,6 & 4,5 \\
\hline
\end{tabular}

$a^{*}$ dentro de cada ítem e de cada variável, as médias seguidas da mesma letra não diferem entre si, pelo teste de Tukey $(P<0,05)$.

De acordo com os resultados apresentados na Tabela 29, no cultivo a campo aberto não houve efeito das coberturas do solo e dos níveis de irrigação nas variáveis produção total, número e peso médio dos frutos.

A produção total alcançada nos dois ambientes de cultivo praticamente não diferiu com o uso do plástico transparente (Tabelas 28 e 29). Por outro lado, com o plástico preto, a produção foi $23 \%$ menor no cultivo 
protegido, quando comparada à obtida no campo aberto. Essa diferença de produção deve estar associada, a maior incidência de doenças observada no plástico preto quando comparado com o transparente, no cultivo protegido (Tabelas 14 e 17).

Os resultados obtidos com relação ao efeito positivo do uso do plástico transparente na produção, quando comparado ao preto (Tabela 28), concordam com os observados por Voth \& Bringhurst (1990), na California, para vários cultivares de morangueiro. Por outro lado, os resultados apresentados na Tabela 29, onde não se verifica efeito das coberturas do solo, são semelhantes aos observados por Martins (1983), em cultivo a campo aberto, com a cv. Campinas, em Viamão, RS. Convém lembrar que, no cultivo protegido, os maiores valores das temperaturas máximas do solo ocorreram sob plástico preto (Figura 3), e, talvez, isso possa ter influenciado os resultados obtidos. Outro aspecto importante a ser considerado é a ocorrência de doenças. No cultivo protegido sob o plástico preto a incidência de doenças foi maior do que sob o plástico transparente (Tabelas 14 e 17), e isso pode ter levado a limitações no potencial produtivo da cultura.

Serrano et al. (1992) em cultivo protegido na Espanha, observaram resultados semelhantes aos apresentados na Tabela 28 , com relação ao efeito dos niveis de irrigação no total de produção.

No campo aberto a ausência de influência dos niveis de irrigação na produção e seus componentes (Tabela 29), deve estar associada às chuvas ocorridas durante a experimentação e a ocorrência de doenças de forma homogênea no experimento. Strabbioli (1988), em Roma, na Itália, também não observou efeito de diferentes níveis de irrigação na produção, tamanho e o número de frutos do morangueiro. $O$ autor associou esse fato às precipitações naturais ocorridas durante a experimentação.

Os valores de produção de frutos por planta no cultivo protegido (Tabela 28) foram elevados, variando de 662,4 a 466,7 g/planta, quando 
comparados aos alcançados por Passos (1997), com o mesmo cultivar, em cultivo protegido (250 a $289 \mathrm{~g} /$ planta). Porém com histórico diferente no que se refere a doenças devido a fungos do solo.

Com relação ao cultivo a campo aberto, nota-se que os valores médios de produção por planta foram sempre maiores que $600 \mathrm{~g} /$ planta para os diferentes níveis de água e coberturas de solo analisados (Tabela 29). Esses valores sugerem que o cv. Campinas tolerou bem, um nível elevado de água no solo, pois no cultivo a campo aberto as plantas receberam mais que 0 dobro de água que no cultivo protegido (Tabelas 5 e 6), e, mesmo assim, manteve elevado o nível de produtividade. Cabe ressaltar que, durante toda a experimentação, o solo em questão se mostrou com boa drenagem interna. No entanto, o manejo das irrigações pode proporcionar economia de água, energia, mão-de-obra e evitar excessos de água favoráveis à ocorrência e desenvolvimento de doenças. Comparando os valores de produção da Tabela 29 aos obtidos em outros trabalhos, em campo aberto, com plantio em abril, utilizando o mesmo cultivar e o plástico preto como cobertura do solo, observase que a produção foi elevada. Em Campinas, Camargo \& Igue (1973) obtiveram produção de $239 \mathrm{~g} /$ planta; em Botucatu, Carbonari (1973) obteve de 230 a 407 g/planta; em Jundiaí, Passos (1982) obteve valores de 246 a 434 g/planta e, em Monte Alegre do Sul, Tessarioli Neto (1993) alcançou 440 g/planta. Com o plástico transparente, em cultivo a campo aberto, com plantio em maio, Martins (1983) encontrou produção na ordem de 300 g/planta, valor bem menor do que o observado na Tabela 29 com essa cobertura.

Os resultados positivos relativos aos níveis de produtividade alcançados, nos dois experimentos, sugerem um ganho de produção devido à desinfestação do solo com brometo de metila, conforme relatado por Kimati (1995), associado aos cuidados nos tratos culturais e aplicação de insumos durante o ciclo da cultura. De acordo com os resultados da Tabela 29, o cv. Campinas mostrou-se produtivo, apesar da incidência de bacteriose, 
denominada mancha angular causada por Xanthomonas fragariae, desde junho (56 dias após o plantio). Os resultados positivos de produção e incidência de doenças no cultivo protegido referendam este sistema de cultivo como ferramenta valiosa para o controle integrado de doenças do morangueiro. 


\section{CONCLUSÕES}

De acordo com as condições em que se realizaram os dois experimentos, pode-se concluir que:

- No cultivo protegido, os níveis de irrigação de -0,010 e -0,035 MPa e o plástico transparente favoreceram o desenvolvimento vegetativo das plantas (altura, máxima dimensão horizontal das plantas, área foliar e índice de área foliar), a produção total de frutos comerciáveis e seus componentes (número e peso médio dos frutos). O nivel de irrigação de $-0,070 \mathrm{MPa}$ e o uso do plástico preto, como cobertura do solo, proporcionaram maior incidência de doenças.

- No cultivo a campo aberto, não houve efeito dos niveis de irrigação e das coberturas do solo no desenvolvimento vegetativo das plantas (altura, DHP, MSPA, AF e IAF), na profundidade efetiva do sistema radicular, na produção de frutos e seus componentes e na sanidade das plantas.

- Em condições de cultivo a campo aberto, foi determinada em $30 \mathrm{~cm}$ a profundidade efetiva do sistema radicular.

- A ocorrência de doenças ao longo do ciclo da cultura diferiu entre o cultivo protegido e a campo aberto. No campo aberto, as doenças foram observadas desde junho, enquanto que no cultivo protegido, as doenças surgiram apenas a partir da segunda quinzena de setembro. 


\section{REFERÊNCIAS BIBLIOGRÁFICAS}

AGRIANUAL 98. Anuário estatístico da agricultura brasileira. FNP Consultoria e Comércio e M. \& S. Mendes \& Scatoni. 1997. p.469.

ALVES, D.R.B.; KLAR, A.E. Comparação de métodos para estimar evapotranspiração de referência em túnel de plástico. Irriga, v.1, n. 2, p. 2634, 1996.

BATAGLIA, O.C.; FURLANI, A.M.C.; TEIXEIRA, J.P.F.; FURLANI, P.R.; GALLO, J.R. Métodos de análise química de plantas. Campinas: Instituto Agronômico, 1983. 48p. (IAC. Boletim Técnico, 78).

BLASSE, W. Intensification of strawberry production by irrigation. Gartenbau, v. 24 , n. 4 , p. $116-118,1977$. /Resumo em CAB Abstracts on CD-ROM 1976-78/.

BLATT, C.R. Irrigation, mulch, and double row planting related to fruit size and yield of "Bounty" strawberry. HortScience, v. 19, n.6, p.826-827, 1984.

BOHM, W. Methods of studying root systems. Berlin: Springer-Verlag, 1979. $189 p$.

BRINGHURST, R.S.; VOTH, V.; SHAW, D. University of Califórnia strawberry breeding. HortScience, v.25, n.8, p.834-999, 1990. 
BURIOL, G.A.; SCHNEIDER, F.M.; STRECK, N.A.; LUFT, S.V.L. Efeito do manejo de túneis baixos de polietileno transparente sobre o microambiente. In: CONGRESSO BRASILEIRO DE AGROMETEOROLOGIA, 9., Campina Grande, 1995. Anais. Campina Grande:SBA, 1995. p.299-301.

BURIOL, G.A.; SCHNEIDER, F.M.; ESTEFANEL, V.; ANDRIOLO, J.L.; MEDEIROS, S.L.P. Modificação na temperatura mínima do ar causada por estufas de polietileno transparente de baixa densidade. Revista Brasileira de Agrometeorologia, v.1, n.1, p.43-49, 1993.

CAMACHO, M.J.C.; ASSIS, F.N.; MARTINS, S.R.; MENDEZ, M.E.G. Avaliação de elementos meteorológicos em estufa plástica em Pelotas, RS. Revista Brasileira de Agrometeorologia. v.3, p.19-24, 1995.

CAMARGO, L. de S. Novas variedades de morangueiro no Estado de São Paulo. Piracicaba, 1960. 48p. Tese (Doutorado) - Escola Superior de Agricultura "Luiz de Queiroz", Universidade de São Paulo.

CAMARGO, L. de S.; IGUE, T. Experiência sobre efeito da cobertura do solo na produção do morangueiro. Bragantia, v.32, n.6, p.149-169, 1973.

CAMARGO, L. de S.; PASSOS, F.A. Morango. In: FURLANI, A.M.C.; VIÉGAS, G.P. (Ed.). O melhoramento de plantas no Instituto Agronômico. Campinas: Instituto Agronômico, 1993. v.1, p.411-432.

CAMARGO, L. de S.; SCARANARI, H.J.; IGUE, T. Ensaio de cultivares e híbridos de morangueiro, Jundiaí. Bragantia, v.33, n.4, p.33-42, 1974.

CAMPOS, S.; KLAR, A.E.; CATANEO, A. Déficits hídricos em plantas de morango (Fragaria spp). I. Resistência a seca. Científica, v.20, n.2, p. 307319, 1992. 
CARBONARI, R. Influência da época de plantio na produção de algumas variedades de morangueiro (Fragaria spp.). Botucatu, 1973. 131p. Tese (Doutorado) - Faculdade de Ciências Médicas e Biológicas de Botucatu Universidade Estadual Paulista Júlio de Mesquita Filho.

CARBONARI, R.; CUNHA, R.S.Q. Produção de três cultivares de morangueiro (Fragaria spp.), submetidas a tratamento fotoperiódico no viveiro de mudas. Revista de Olericultura, v.15, p.69-70, 1975.

CASTELLANE, P.D. Nutrição e adubação do morangueiro. In: SIMPÓSIO SOBRE NUTRIÇÃO E ADUBAÇÃO DE HORTALIÇAS, Jaboticabal, 1990. Anais. Piracicaba: POTAFOS, 1993. p.261-279.

DAKER, A. Irrigação e drenagem; a água na agricultura. 7.ed. Rio de Janeiro: Livraria Freitas Bastos, 1988. v.3, 543p.

DENNIS Jr., F.G.; LIPEKCI, J.; KIANG, C.H. Effect of photoperiod and other factors upon flowering and runner development of three strawberry cultivars. Journal of the American Society for Horticultural Science, v.95, p.750754, 1970.

DOORENBOS, J.; PRUITT, W.O. Crop water requirements. Rome: FAO, 1984. 144p. (FAO. Irrigation and Drainage Paper, 24).

DWYER, L.M.; STEWART, D.W.; HOUWING, L.; BALCHIN, D. Response of strawberries to irrigation scheduling. HortScience, v.22, n.1, p.42-44, 1987.

FAO PRODUCTION YEARBOOK - 1994, v.48, p.168, 1995. (FAO Statistics Series, 125). 
FARIAS, J.R.B.; BERGAMASCHI, H.; MARTINS, S.R.; BERLATO, M.A. Efeito da cobertura plástica de estufa sobre a radiação solar. Revista Brasileira de Agrometeorologia, v.1, n.1, p.31-36, 1993a.

FARIAS, J.R.B.; BERGAMASCHI, H.; MARTINS, S.R.; BERLATO, M.A.; OLIVEIRA, A.C.B. Alterações na temperatura e umidade relativa do ar provocadas pelo uso de estufa plástica. Revista Brasileira de Agrometeorologia, v.1, n.1, p.52-62, 1993b.

FILGUEIRA, F.A.R. Manual de olericultura: cultura e comercialização de hortaliças. 2.ed. São Paulo: Agronômica Ceres, 1982. 357p.

FIGUEIREDO, M.B.; TERANISHI, J.; CARDOSO, R.M.G. Estudos sobre espécies do gênero Verticillium parasitas de plantas no Estado de São Paulo. Revista da Sociedade Brasileira de Fitopatologia, v. 4, n. 4, p.10$11,1971$.

FUJIWARA, M.; KURACHI, S.A.H.; ARRUDA, F.B.; PIRES, R.C. de M.; SAKAI, E. A técnica de estudo de raizes pelo método do trado. Campinas: Instituto Agronômico, 1994. 9p. (IAC. Boletim Técnico, 153).

GALLETTA, G.J.; BRINGHURST, R.S. Strawberry management. In: GALLETTA, G.J.; HIMELRICK, D.G. (Ed.). Small fruit crop management. Englewood Cliffs: Prentice Hall, 1990. cap.3, p.83-156.

GEHRMANN, H. Growth, yield and fruit quality of strawberries as affected by water supply. In: INTERNATIONAL SYMPOSIUM ON WATER RELATIONS IN FRUIT CROPS, 1., Pisa, 1984. Acta Horticulturae, n.171, p.463-469, 1985. 
GIOVANARDI, R.; TESTOLIN, R. Evapotranspiration and yield response of strawberry (Fragaria $X$ ananassa Duch.) as affected by soil water conditions. Irrigazione, v. 31, n. 4, p. 15-23, 1984. /Resumo em CAB Abstracts on CDROM, 1984-86/.

GOULART, B.L.; FUNT, R.C. Influence of raised beds and plant spacing on growth and yield of strawberry. Journal of the American Society for Horticultural Science, v.111, n. 2, p. 176-181, 1986.

GROHMANN, F.; RAIJ, B. van. Influência dos métodos de dispersão da argila do solo. In: CONGRESSO BRASILEIRO DE CIÊNCIA DO SOLO, 14., Santa Maria, 1973. Anais. Santa Maria: Sociedade Brasileira de Ciência do Solo, 1974. p.123-132.

GROPPO, G.A.; TESSARIOLI NETO, J. A cultura do morangueiro. Campinas: CATI, 1991. 16p. (CATI. Boletim Técnico, 201).

GUPTA, R.; ACHARYA, C.L. Effect of mulch induced hydrothermal regime on root growth, water use efficiency, yield and quality of strawberry. Journal of the Indian Society of Soil Science, v.41, n.1, p.17-25, 1993. /Resumo em CAB Abstracts on CD-ROM, 1995/.

HAISE, H.R.; HAGAN, R.M. Soil, plant, and evaporative measurements as criteria for scheduling irrigation. In: HAGAN, R.M.; HAISE, H.R.; EDMINSTER, T.W. Ed. Irrigation of agricultural lands. Madison: American Society of Agronomy, 1967. cap. 9, p.577-604.

HAM, J.M.; KLUITENBERG, G.J.; LAMONT, W.J. Optical properties of plastic mulches affect the field temperature regime. Journal of the American Society for Horticultural Science, v.118, n.2, p.188-193, 1993. 
HANCOCK, J.F. Ecological genetics of natural strawberry species. HortScience, v.25, p.869-871, 1990.

HARTZ, T.K.; DE VAY, J.E. ELMORE, C.L. Solarization is an effective soil disinfestation technique for strawberry production. HortScience, v. 28, n. 2 , p. 104-106, 1993.

HIMELRICK, D.G.; DOZIER Jr., W.A.; AKRIDGE, J.R. Effect of mulch type in annual hill strawberry plasticulture systems. In: INTERNATIONAL STRAWBERRY SYMPOSIUM, 2., Beltsville, 1992. Trabalhos apresentados. Acta Horticulturae, n. 348, p.207-209, 1993.

INFORZATTO, R.; CAMARGO, L. de S. Sistema radicular do morangueiro (Fragaria híbridos), em duas fases do ciclo vegetativo. Bragantia, v.32, n.8, p.185-191, 1973.

IUCHI, T. Crescimento da planta e do fruto de morangueiro (Fragaria $x$ ananassa Duch.) em diferentes regimes hídricos. Viçosa, 1993. 187p. Tese (Doutorado) - Universidade Federal de Viçosa.

KELLER, J.; KARMELI, D. Trickle irrigation design parameters. Transactions of the ASAE, p.678-684, 1974.

KIMATI, H. Controle químico. In: BERGAMIN FILHO, A.; KIMATI, H.; AMORIM, L. (Ed.). Manual de fitopatologia. 3.ed. São Paulo: Agronômica Ceres, 1995. v.1, cap. 38, p.761-785.

KLAR, A.E.; CAMPOS, S.; CATÂNEO, A. Déficits hídricos em plantas de morango (Fragaria spp). I. Produção, teores de vitamina $\mathrm{C}$, de proteína e umidade dos frutos. Científica, v. 18, n. 2, p. 45-61, 1990. 
LARSON, K.D.; SHAW, D.V. Relative performance of strawberry genotypes on fumigated and nonfumigated soils. Journal of the American Society for Horticultural Science, v. 120, n. 2, p. 274-277, 1995.

LIAKATAS, A.; CLARK, J.A.; MONTEITH, J.L. Measurements of the heat balance under plastic mulches. Agricultural and Forest Meteorology, v.36, p.227-239, 1986.

LISBÃO, R.S.; SIQUEIRA, W.J.; TRANI, P.E.; NAGAI, H.; FORNAZIER, J.B.; PASSOS, F.A.; MELO, A.M.T.; YUKI, V.A.; PIZZINATTO, M.A.; TANAKA, M.A.S.; MAEDA, J.A. Diagnóstico e programa de Pesquisa de Hortaliças. Campinas: Instituto Agronômico, Comissão Científica de Diagnóstico de Hortaliças, 1991. 83p.

LOCASCIO, S.J.; MYERS, J.M. Trickle irrigation and fertilization method for strawberries. In: ANNUAL MEETING OF THE FLORIDA STATE HORTICULTURAL SOCIETY, Deland, 1975. Proceedings of the Florida State Horticultural Society, v.88, p.185-189, 1975.

LOCASCIO, S.J.; MYERS, J.M.; MARTIN, F.G. Frequency and rate of fertilization with trickle irrigation for strawberries. Journal of the American Society for Horticultural Science, v.102, n.4, p.456-458, 1977.

LUCCHESI, A.A.; MINAMI, K. Análise quantitativa de crescimento vegetal em cultivares de morangueiro (Fragaria spp.), sob a influência de fitoreguladores de crescimento. Anais da Escola Superior de Agricultura Luiz de Queiroz, v.37, p.555-593, 1980.

MAAS, J.L. (Ed.). Compendium of strawberry diseases. St. Paul: The American Phytopathological Society, 1984. 138p. 
MACHADO, J. da C. Morangueiro. Informe agropecuário, v.11, n.131, p.3740, 1985.

MAROUELLI, W.A.; SILVA, W.L. de C.; SILVA, H.R. Manejo da irrigação em hortaliças. Brasília: EMBRAPA, CNPH, 1994. 60p.

MARTINS, G.; CASTELLANE, P.D.; VOLPE, C.A. Influência da casa-devegetação nos aspectos climáticos e em época de verão chuvoso. Horticultura Brasileira, v.12, n.2, p.131-135, 1994.

MARTINS, N.L.F. Efeitos de coberturas plásticas e orgânicas sobre o rendimento de "frutos"de duas cultivares de morangueiro (Fragaria $x$ ananassa Duch.) e a temperatura do solo. Porto Alegre, 1983. 252p. Dissertação (Mestrado) - Faculdade de Agronomia, Universidade Federal do Rio Grande do Sul.

McINNES. T.B.; BLACK, L.L.; GATTI, J.M. Disease-free plants management of strawberry anthracnose crown rot. Plant Disease, v.76, p.260-264, 1992.

MCNIESH, C.M.; WELCH, N.C.; NELSON, R.D. Trickle irrigation requirements for strawberries in Coastal Califórnia. Journal of the American Society for Horticultural Science, v.110, n.5, p.714-718, 1985.

MEDINA, H.P.; GROHMANN, F. Contribuição ao estudo da análise granulométrica do solo. In: CONGRESSO BRASILEIRO DE CIÊNCIA DO SOLO, 6., Salvador, 1962. Anais. Rio de Janeiro:Sociedade Brasileira de Ciência do Solo, 1967. p.29-38. 
MONTERO, J.I.; CASTILLA, N.; GUTIERREZ DE RAVÉ, E.; BRETONES, F. Climate under plastic in the Almeria area. In: GREENHOUSE CONSTRUCTION AND COVERING MATERIALS, Karlsruhe, 1984. Acta Horticulturae, n.170, p.227-234, 1985.

NELSON, P.E.; WILHEM, S. Some anatomic aspects of the strawberry root. Hilgardia, v.26, n.15, p.631-642, 1957.

NESTBY, R. Yield and yield components of four strawberry cultivars with and without plastic tunnels in the years 1976-1978. Forskning of Forsolk e Landbruket, v. 30, n. 5, p. 433-442, 1979. /Resumo em CAB Abstracts on CD - ROM, 1979-81/.

OKAYAMA, K. Incidence of strawberry anthracnose, environmental factors, disease resistence of cultivars and chemical controls. Bulletin of the Nara Agricultural Experiment Station, n.20, p.79-86. 1989. IResumo em CABABSTRACTS on CD-ROM 87-89/.

OLITTA, A.F.L. Efeito da irrigação por gotejo no desenvolvimento vegetativo e produção da cultura do morango (Fragaria sp.). Piracicaba, 1980. 79p. Tese (Livre-docência) - Escola Superior de Agricultura "Luiz de Queiroz", Universidade de São Paulo.

OLITTA, A.F.L.; MINAMI, K. Irrigação por gotejo em morango. Anais da Escola Superior de Agricultura "Luiz de Queiroz", v.31, p.713-720, 1974.

OLITTA, A.F.L.; MINAMI, K. Influência da cobertura de solo na cultura do morango (Fragaria sp.). O Solo, v.67, p.31-34, 1975.

O'NEIL, S.D. Role of osmotic potential gradient durring water stress and leaf senescence in Fragaria virginiana. Plant Physiology, v.72, p.931-937, 1983. 
PARISOT, E. Research programme on temperate fruits in reunion Island evolution and perspectives. In: INTERNATIONAL WORKSHOP ON TEMPERATE ZONE FRUITS IN THE TROPICS AND SUBTROPICS, 3., Chiang Mai, 1988. Trabalhos apresentados. Acta Horticulturae, n.279, p.139-154, 1990.

PASSOS, F.A. Caracterização de clones nacionais e introduzidos de morangueiro (Fragaria x ananassa Duch.), visando o uso imediato na horticultura e o melhoramento genético. Piracicaba, 1982. 116p. Dissertação (Mestrado) - Escola Superior de Agricultura "Luiz de Queiroz", Universidade de São Paulo.

PASSOS, F.A. Influência de alguns sistemas de cultivo na cultura do morango (Fragaria x ananassa Duch.). Piracicaba, 1997. 106p. Tese (Doutorado) Escola Superior de Agricultura "Luiz de Queiroz", Universidade de São Paulo.

PASSOS, F.A.; TRANI, P.E.; BETTI, J.A.; TANAKA, M.A.S. Morango. In: INSTITUTO AGRONÔMICO DE CAMPINAS. Instruções agrícolas para o Estado de São Paulo. 6.ed. Campinas, p.222-225, 1998. (IAC. Boletim, 200).

PEÑUELAS, J.; SAVÉ, R.; MARFÀ, O.; SERRANO, L. Remotely measured canopy temperature of greenhouse strawberries as indicator of water status and yield under mild and very mild water stress conditions. Agricultural and Forest Meteorology, v. 58, p. 63-77, 1992. 
PEZZOPANE, J.E.M. Uso de estufa com cobertura plástica e de quebra-ventos na produção de porta-enxertos de seringueira, na região de Campinas-SP. Piracicaba, 1994. 87p. Dissertação (Mestrado) - Escola Superior de Agricultura "Luiz de Queiroz", Universidade de São Paulo.

PEZZOPANE, J.E.M.; PEDRO JUNIOR, M.J.; ORTOLANI, A.A. Modificações microclimáticas provocadas por estufa com cobertura plástica. Bragantia, v.54, n.2, p.419-425, 1995.

PIRES, R. C. de M.; ARRUDA, F.B. Método para cálculo do intervalo de irrigação suplementar. Bragantia, v.54, n.1, p.193-200, 1995.

PIRES, R. C. de M.; ARRUDA, F.B.; BENATTI JUNIOR, R.; TOSELLO, R.N.; MEDINA, J.C. Rami: análise de cinco anos de irrigação e adubação em Campinas. Bragantia, v.47, n.2, p.341-352, 1988.

POMARES, F.; TARAZONA, F.; ESTELA, M. Fertilizacion nitrogenada del freson en Valencia em plantacion de verano com riego por goteo y por surcos. Investigación Agraria. Producción y Protección Vegetales, v. 9 , n. 1, p. 73-84, 1994.

RAIJ, B. van; ZULLO, M.A.T. Métodos de análise do solo. Campinas: Instituto Agronômico, 1977. 16p. (IAC. Circular, 63).

RAIJ, B. van; CANTARELLA, H.; QUAGGIO, J.A.; FURLANI, A.M.C. (Ed.). Recomendações de adubação e calagem para o Estado de São Paulo. 2.ed. Campinas: IAC, 1996. 285p. (IAC. Boletim Técnico, 100). 
RAMALHO SOBRINHO, R.; CORREIA, L.G.; SALGADO, J.R. Olericultura no Brasil: área (ha) e produção (t) por cultura e por Estado no ano de 1990. In: CONGRESSO BRASILEIRO DE OLERICULTURA, 31., Belo Horizonte, 1991. Palestras. Belo Horizonte: EMATER,1991. p. 174-183.

RODRIGUES NETO, J.; MALAVOLTA Jr., V.A.; PRATES, H.S.; SINIGAGLIA, C. Ocorrência da "mancha angular" em cultivos de morangueiro, no Estado de São Paulo. Campinas: CATI, 1994. 2p. (CATI. Comunicado Técnico, 121).

ROSSI PISA, P.; ROSATI, P.; GASPARI, N. Lysimetric measurements of water consumed by day-neutral strawberry cv. Fern. In: INTERNATIONAL STRAWBERRY SYMPOSIUM, 1., Cesena, 1988. Acta Horticulturae, n.265, p.251-258, 1989.

ROTEM, J.; PALTI, J. Irrigation and plant diseases. Annual Review of Phytopathology, v.7, p.267-288, 1969.

SCHNEIDER, F.M.; BURIOL, G.A.; ANDRIOLO, J.L.; ESTEFANEL, V.; STRECK, N.A. Modificação na temperatura do solo causada por estufas de polietileno transparente de baixa densidade em Santa Maria, RS. Revista Brasileira de Agrometeorologia, v.1, n.1, p.37-42, 1993.

SECRETARIA DE AGRICULTURA E ABASTECIMENTO DE SÃO PAULO. Programa paulista de apoio à cultura do morango. São Paulo, 1996. $13 p$. 
SEONG, K.C.; CHEONG, S.R.; YU, I.C.; KIM, K.Y.; PARK, S.K. Effects of irrigation methods and covering materials on the occurrence of grey mould (Botrytis cinerea) in strawberry (Fragaria $X$ ananassa Duch.) in protected culture. RDA - Journal of Agricultural Science Horticulture, v. 35, n. 1, p. 501-506, 1993.

SERRANO, L.; CARBONELL, X.; SAVÉ, R.; MARFÀ, O.; PEÑUELAS, J. Effects of irrigation regimes on the yield and water use of strawberry. Irrigation Science, v.13, p.45-48, 1992.

SGANZERLA, E. Nova agricultura: a fascinante arte de cultivar com os plásticos. 5.ed. Guaíba: Ed. Agropecuária, 1995. 342p.

SMITH, B.J.; BLACK, L.L. Resistance of strawberry plants to Colletotrichum fragariae affected by environmental conditions. Plant Disease, v. 71, n.9, p.834-837, 1987.

SNEDECOR, G.W.; COCHRAN, W.G. Statistical methods. Ames: lowa State University, 1973. 593p.

SOUZA, A.F.; HAAG, H.P.; OLIVEIRA, G.D. de; SARRUGE, J.R.; MINAMI, K. Absorção de micronutrientes por quatro cultivares de morangueiro (Fragaria spp.). In: HAAG, H.P.; MINAMI, K. (Ed.). Nutrição mineral em hortaliças. Campinas: Fundação Cargill, 1981a. p.375-417.

SOUZA, A.F.; HAAG, H.P.; SARRUGE, J.R.; OLIVEIRA, G.D. de; MINAMI, K. Absorção de macronutrientes por quatro cultivares de morangueiro (Fragaria spp.). In: HAAG, H.P.; MINAMI, K. (Ed.). Nutrição mineral em hortaliças. Campinas: Fundação Cargill, 1981b. p.327-374. 
STANLEY, C.D.; MAYNARD, D.N. Vegetables. In: STEWART, B.A; NIELSEN, D.R. (Ed.). Irrigation of agricultural crops. Madison: American Society of Agronomy, Crop Science Society of America, Soil Science Society of America, 1990. cap.31, p.921-947.

STOLF, R.; FERNANDES, J.; FURLANI NETO, V. Penetrômetro de impactomodelo IAAPlanalsucar - STOLF (Recomendações para o seu uso). STAB, v.1, n.3, p.18-23, 1983.

STRABBIOLI, G. A study on strawberry water requirements. In: INTERNATIONAL SYMPOSIUM ON WATER SUPPLY AND IRRIGATION IN THE OPEN AND UNDER PROTECTED CULTIVATION, 4., Padova, 1985. Acta Horticulturae, n.228, p.179-186, 1988.

TANAKA, M.A.S.; FEITOSA, C.T.; PASSOS, F.A. Reação do morangueiro ao Colletotrichum fragariae em diferentes niveis de fertilidade do solo. In: CONGRESSO BRASILEIRO DE FITOPATOLOGIA, 28., Ilhéus, 1995. Resumos. Fitopatologia Brasileira, v.20, p.343, 1995.

TENNANT, D. A test of modified line intersect method of estimating root length. Journal of Ecology, v.63, n.3, p.995-1001, 1975.

TESSARIOLI NETO, J. Influência de cobertura permeável e impermeável sobre - solo e planta na produção do morangueiro (Fragaria $x$ ananassa Duch.). Piracicaba, 1993. 112p. Tese (Doutorado) - Escola Superior de Agricultura "Luiz de Queiroz", Universidade de São Paulo.

TRANI, P.E.; HIROCE, R.; BATAGLIA, O.C. Análise foliar: amostragem e interpretação. Campinas: Fundação Cargill, 1983. 18p. 
ULRICH, A.; MOSTAFA, M.A.E.; ALLEN, W.W. Strawberry deficiency symptoms: a visual and plant analysis guide to fertilization. Oakland: University of California, 1980. 58p. (Publication, 4098).

VOTH, V. Plastics in the California strawberries. HortScience, v.7, n.4, p.378380, 1972.

VOTH, V.; BRINGHURST, R.S. Culture and physiologycal manipulation of Califórnia strawberries. HortScience, v.25, n.8, p.889-892, 1990.

WING, K.B.; PRITTS, M.P.; WILCOX, W.F. Biotic, edaphic, and cultural factors associated with strawberry black root rot in New York. HortScience, v.30, n.1, p.86-90, 1995.

YANG, X.; MADDEN, L.V.; REICHARD, D.L.; WILSON, L.L.; ELLIS, M.A. Splash dispersal of Colletotrichum acutatum and Phytophthora cactorum from strawberry fruit by single drop impactions. Phytopathology, v.82, n.3, p.332-340, 1992.

YANG, X.; WILSON, L.L.; MADDEN, L.V.; ELLIS, M.A. Rain splash dispersal of Colletotrichum acutatum from infected strawberry fruit. Phytopathology, v.80, n.6, p.590-595, 1990.

ZULLO Jr., J.; ARRUDA, F.B. Programa computacional para ajuste de equações em dados experimentais. Campinas: Instituto Agronômico, 1987. 31p. (IAC. Boletim Técnico, 113). 